\title{
The "Boom" and "Bust" Patterns of Communities within the Energy Rich Region of West Virginia: A Case Study of Moundsville
}

\author{
Brandon S. Kiger
}

Follow this and additional works at: https://researchrepository.wvu.edu/etd

\section{Recommended Citation}

Kiger, Brandon S., "The "Boom" and "Bust" Patterns of Communities within the Energy Rich Region of West Virginia: A Case Study of Moundsville" (2015). Graduate Theses, Dissertations, and Problem Reports.

5972.

https://researchrepository.wvu.edu/etd/5972

This Thesis is protected by copyright and/or related rights. It has been brought to you by the The Research Repository @WVU with permission from the rights-holder(s). You are free to use this Thesis in any way that is permitted by the copyright and related rights legislation that applies to your use. For other uses you must obtain permission from the rights-holder(s) directly, unless additional rights are indicated by a Creative Commons license in the record and/ or on the work itself. This Thesis has been accepted for inclusion in WVU Graduate Theses, Dissertations, and Problem Reports collection by an authorized administrator of The Research Repository @ WVU. For more information, please contact researchrepository@mail.wvu.edu. 
The "Boom" and "Bust” Patterns of Communities within the Energy Rich Region of West Virginia: A Case Study of Moundsville

\author{
Brandon S. Kiger
}

Thesis submitted to the Davis College of Agriculture, Natural Resources, and Design at West Virginia University in partial fulfillment of the requirements

for the degree of

\author{
Master of Science \\ in \\ Design and Merchandising \\ Hodjat Ghadimi, Ph.D., Chair \\ Chris Haddox, Ph.D. \\ Jessica Blythe, Ph.D.
}

School of Design and Community Development

Morgantown, West Virginia

2015

Keywords: sustainable design, sustainable development, wicked problems, case study, community development, inclusive wealth, natural capital, physical capital, human capital, energy rich regions, natural resource curse

Copyright 2015 Brandon S. Kiger 


\begin{abstract}
The "Boom” and "Bust” Patterns of Communities within the Energy Rich Region of West Virginia: A Case Study of Moundsville
\end{abstract}

\title{
Brandon S. Kiger
}

The increasing worldwide demand for energy will provide Energy Rich Regions (ERRs) the opportunity to increase their wealth and quality of living. However, a reoccurring pattern of boom and bust cycles in ERRs suggests the need for more sustainable development strategies.

A mixed methods approach (case study) is employed to explore the "wicked human problems" occurring in one community, Moundsville, WV and to discover development patterns that might inform sustainable development strategies for the future.

This study explores briefly the distant past development patterns, and in greater detail the pre-boom and most current boom in natural gas. First, data will be derived from a conceptual "Energy Rich Region Template" that explores the sustainability of development from the inclusive wealth forms of natural, human, and physical capital. The qualitative data analysis software (MAXQDA) is used to systematically collect and organize data and information into a community-wide knowledge base (specifically seven years of city council minutes).

This framework can assist future research dedicated to similar cases. Furthermore, this case may support communities and or policymakers in the development of a programming guide for converting the natural capital into other reproducible capital forms, thus avoiding the development cycle of boom and bust. 


\section{Dedication}

I would like to dedicate my thesis to first and foremost my wife, Deepa. Additionally, I would especially like to thank my mom and family who have been my 'cheering squad' throughout my life. This has been a long journey and my wife and family have been a source of encouragement all along the way. There have been so many opportunities where I could have given up. There were many challenges throughout my younger years beginning with the loss of my dad at age three. I know my dad would be proud of me. More recently, it would have been easy to walk away from this research process while moving out-of-state to Colorado, starting a new job, and helping my wife start her own business. I am extremely grateful for having a loving and supportive wife and family, and a Mom who raised me well! Overcoming these challenges has made life more fulfilling and has in turn made me a stronger person with the help from friends and family. 


\section{Acknowledgements}

I am profoundly grateful for the guidance, expertise, and ‘push’ from my lead chair Dr. Ghadimi. He has been there for me from the very beginning and I will never forget one of his first lectures where he introduced this concept of "Boom and Bust" and allowed me to explore sustainable development differently. Furthermore, he has given me opportunities and challenges that have greatly enhanced my research skills which ultimately led to my current job at the National Renewable Energy Laboratory. Thank you!

And because this has been a long process, there have been other committee members who I know wish they could have seen my thesis to the end, but did assist me at the beginning of my research and gave me opportunities to increase my desire for learning and taught me to remain curious—-thank you Dr. Mcfall and Dr. Burnett.

More recently, Dr. Haddox joined the committee who has always been a source of inspiration and support. I admire his willingness to help others and his love and skill for teaching. I'll never forget that it was he who went out of his way to meet with me and discuss my potential future academic career and interests. Thank you for opening that door.

Finally, I would like to thank Dr. Odell for reaching out to Dr. Blythe to become a part of my committee. I am extremely grateful for her to fill in at the last minute and provide me with helpful comments and feedback. Dr. Odell kept the ball moving. He is a great leader and listener, and has always gone out of his way to meet with grad students. In my opinion, he has seemingly managed the change and transformation of our department with ease. I think the School of Design and Community Development has an even brighter future because of him. 


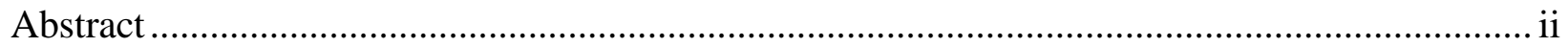

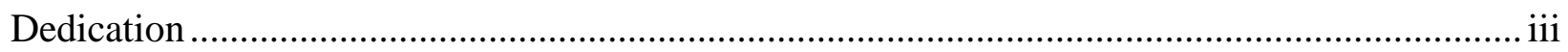

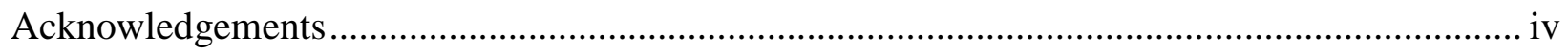

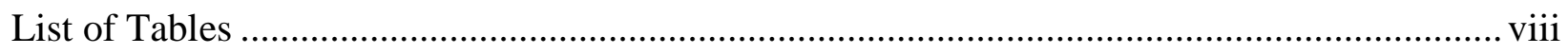

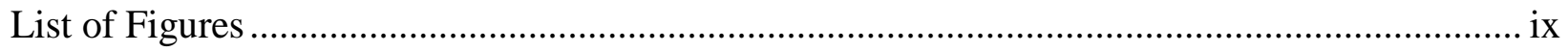

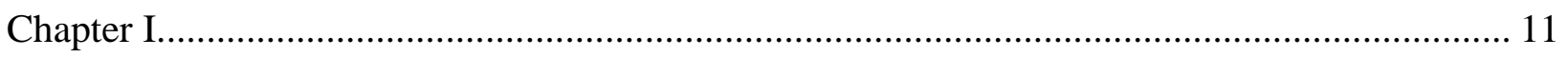

Problem Statement ..................................................................................... 11

Objectives of the Study ................................................................................ 15

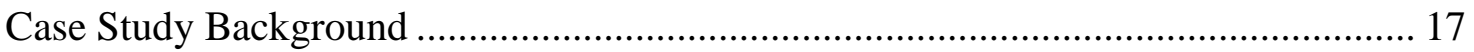

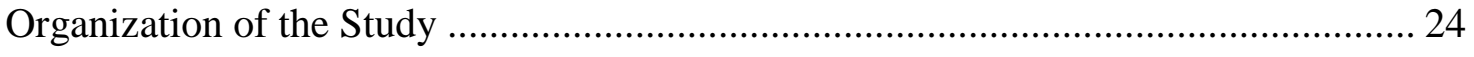

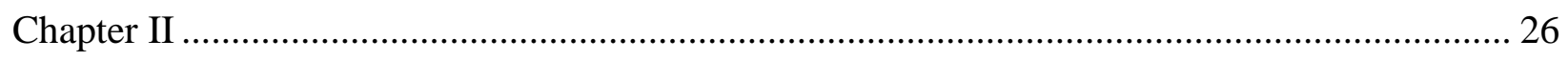

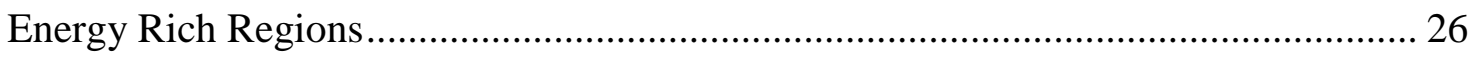

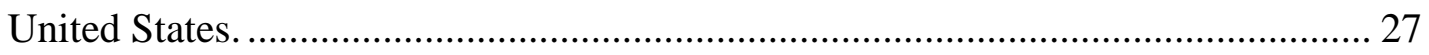

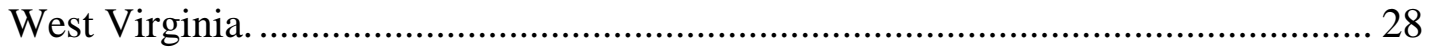

Moundsville—Small Town Rural West Virginia. ............................................... 29

Sustainable development: Concepts, theory and in practice .................................... 32

Sustainable Development (UN Agenda 21)..................................................... 35

President’s Council for Sustainable Development (1993-1999). ........................... 36

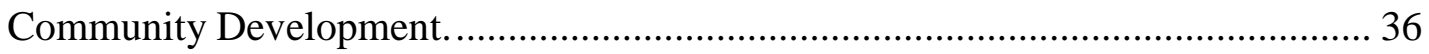


Criteria for success and measurement.

The Natural Resource Curse ............................................................................... 45

West Virginia’s history of non-renewable resources............................................ 46

Linking Moundsville’s boom and bust development patterns to theory. ................. 49

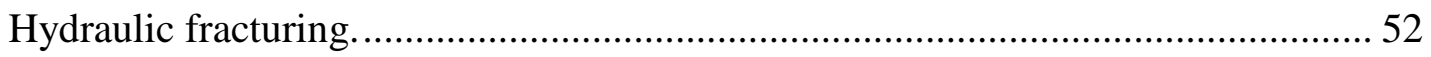

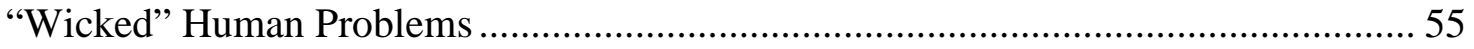

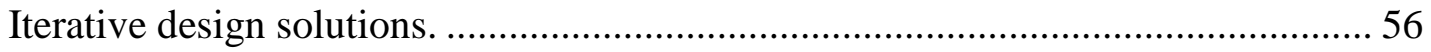

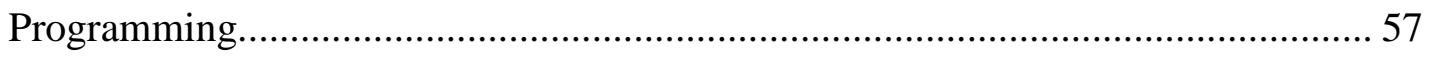

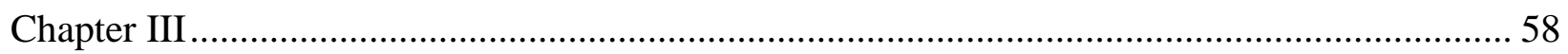

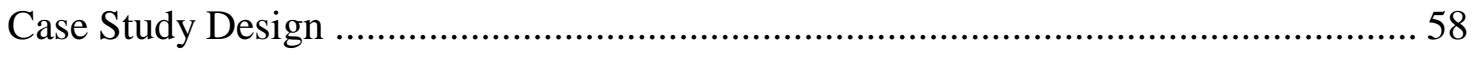

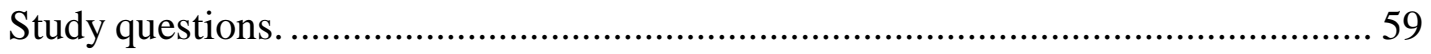

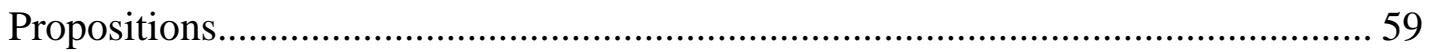

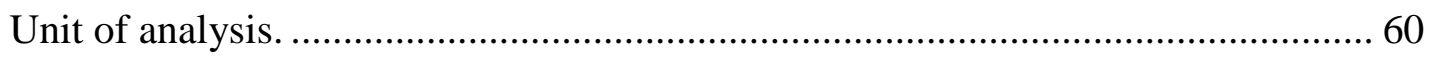

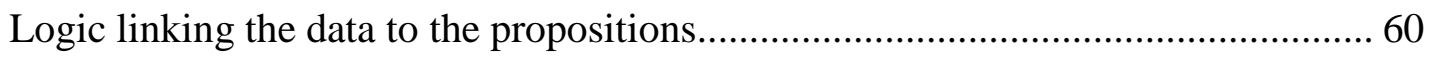

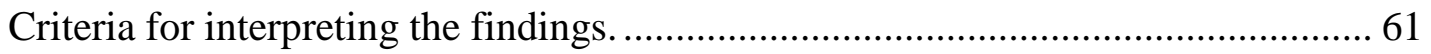

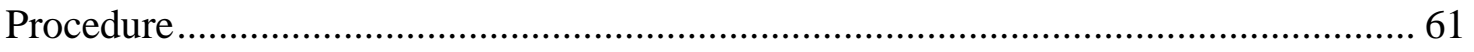

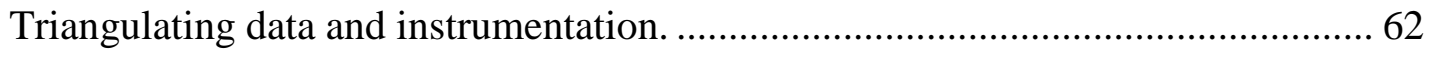

Tools for analyzing the Moundsville knowledge base. ....................................... 65

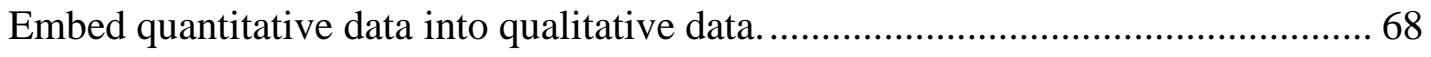

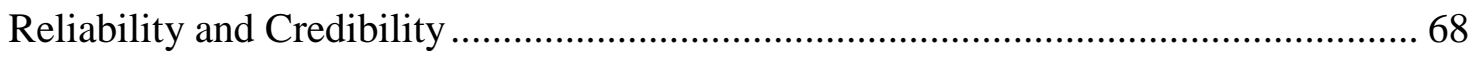




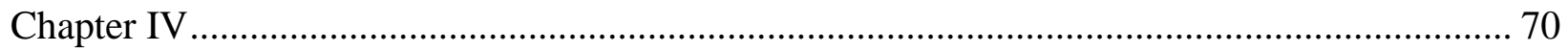

Community Wealth (Assets) …………………………............................................. 70

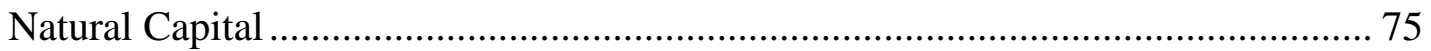

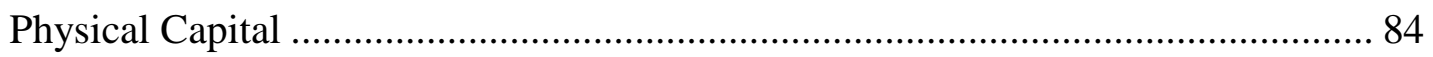

Human Capital .................................................................................................. 92

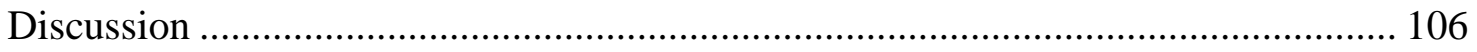

Recent Developments ............................................................................................. 109

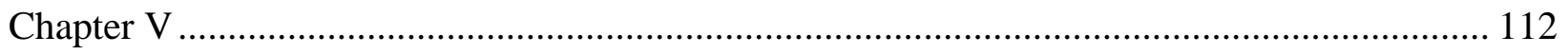

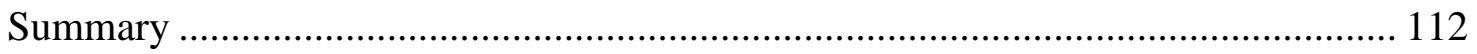

Major Findings ..................................................................................................... 113

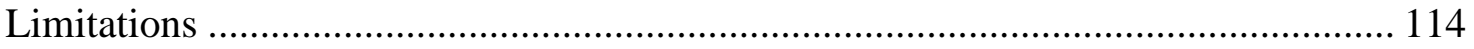

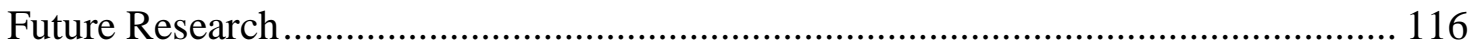

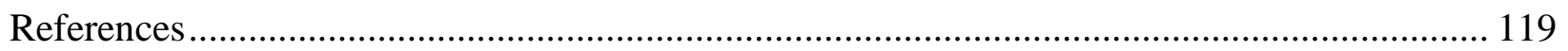

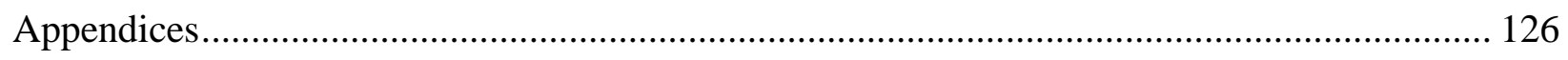

Appendix A: Energy Rich Region (ERR) Template................................................................ 126

Appendix B: MAXQDA Open Coding System with Frequencies and Number of Documents. 131

Appendix C: Participant Observation Photos of Moundsville, West Virginia.............................. 135 


\section{List of Tables}

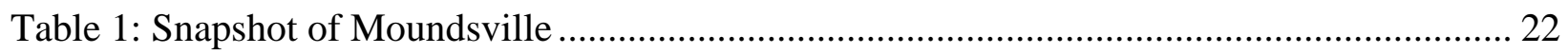

Table 2: U.S. State Total Energy Production and Consumption Rankings, as of 2011............... 29

Table 3: MAXQDA Aggregate Codes for Moundsville City Council Minutes, 2006-2012........ 73

Table 4: Median Household Income Comparison ........................................................... 81

Table 5: Land Cover Distribution of Marshall County....................................................... 82

Table 6: Total Physical Capital with Sub-Codes Percentage vs. the Independent Variable Year.88

Table 7: Moundsville City Limits Camper Count as of Aug. 15, 2012................................... 90

Table 8: Population Percent Change Comparison ............................................................ 94

Table 9: Population Demographics Comparison .............................................................. 95

Table 10: West Virginia State Tax Revenues, 2006-2013 (\$000) ........................................... 100

Table 11: Industry Cluster LQ and Employment Comparison, 2006-2012 for Marshall County

Table 12: Time Series Analysis of Natural, Physical, and Human Capital Interplay with Natural

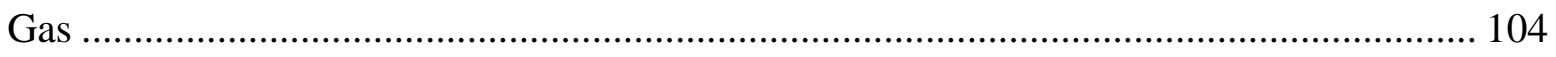

Table 13: Implementation Matrix for Goal 5-Properly Plan for the Natural Gas Industry...... 111 


\section{List of Figures}

Figure 1. Estimated Difference in West Virginia Future Fund Versions by the West Virginia

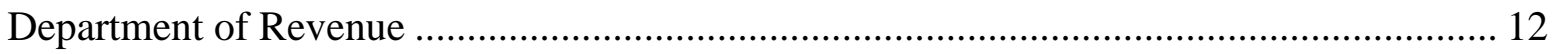

Figure 2. Stages of Resource Depletion Model ................................................................ 15

Figure 3.Total Capital Stock Conversion Model ............................................................. 16

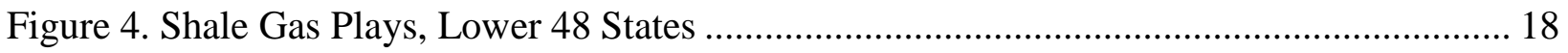

Figure 5. Historical Natural Gas Activity in West Virginia. ................................................. 19

Figure 6. Annual U.S. Natural Gas Wellhead Price ........................................................... 20

Figure 7. Natural Gas Activity in Marshall County, by Completed and Permitted Wells, Sept.

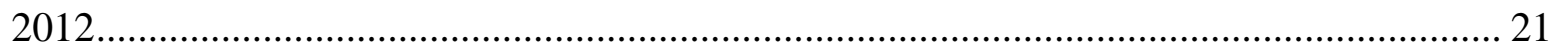

Figure 8. Fostoria Glass Company Brownfield, Moundsville, WV, July, 2006........................ 23

Figure 9. Delimitations Process for Case of Moundsville Literature Review........................... 24

Figure 10. History of Energy Consumption in the U.S. (1776-2012) ..................................... 28

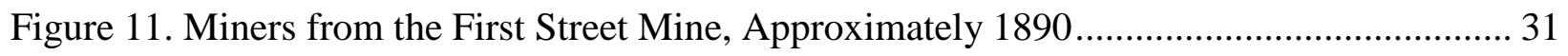

Figure 12. Rapid and Uncontrolled Oil Production in the Past, Spindletop, TX, 1903.............. 44

Figure 13. Rapid and Uncontrolled Gas Production Present Day, Public Land, Western

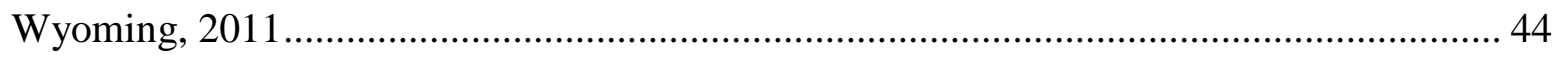

Figure 14. Appalachian Natural Gas History Timeline .................................................... 48

Figure 15. Gilmore’s Problem Triangle ..................................................................... 51

Figure 16. The Process of Hydraulic Fracturing............................................................... 53

Figure 17. Mixed Methods Approach Process for the Case of Moundsville.............................. 62

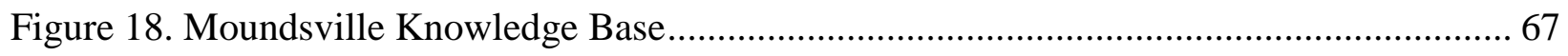

Figure 19. The Community of Moundsville ................................................................... 71 
Figure 20. Grave Creek Mound

Figure 21. MAXQDA Results Total Percent Proportion of Natural Capital with Primary Subcodes. 75

Figure 22. Historical Natural Gas Activity for Marshall County. ........................................ 77

Figure 23. Marshall County Well Production 2006-2013 .................................................. 77

Figure 24. Permitted Marcellus Wells as of June 2013 ...................................................... 79

Figure 25. Completed Marcellus Wells as of June 2013 ..................................................... 80

Figure 26. Median Household Income (as of 2012) vs. Natural Gas Activity (as of June, 2013).81

Figure 27. Marshall County Completed and Permitted Wells ................................................ 83

Figure 28. MAXQDA Results Total Percent Proportion of Physical Capital with Primary Subcodes. 84

Figure 29. City of Moundsville Existing Land Use Map ..................................................... 85

Figure 30. Moundsville Bridge Leading into Ohio.......................................................... 86

Figure 31. Empty Store Fronts, Main Street, Moundsville................................................ 87

Figure 32. Portable Toilets and Campers Resulting from the Boom in Natural Gas, Moundsville.

Figure 33. Marshall County Gas and Hazardous Pipelines ................................................ 91

Figure 34. MAXQDA Results Total Percent Proportion of Human Capital with Primary Sub-

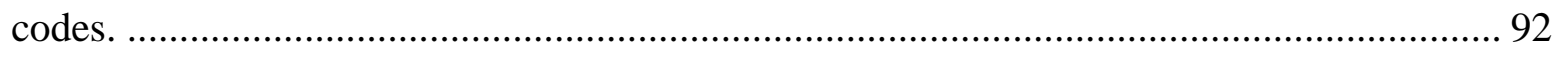

Figure 35. Population Boom and Bust in Marshall County and Moundsville........................... 93

Figure 36. Severance Tax Revenue Trend in West Virginia (\$000)...................................... 101

Figure 37. Human Capital Index for Marshall County ..................................................... 103 
Figure 38. MAXQDA Crosstabs Function for Illustrating Time Series of Natural, Physical, and Human Capital .............................................................................................. 105

Figure 39. MAXQDA Crosstabs Function for Illustrating Time Series of Community Efficacy. 106

Figure 40. Moundsville Penitentiary, Moundsville .......................................................... 135

Figure 41. Moundsville Penitentiary, Moundsville. .......................................................... 135

Figure 42. Exterior Strand Theater, Moundsville ............................................................ 136 


\section{Chapter I}

\section{Introduction}

\section{Problem Statement}

With the demand for energy to increase, Energy Rich Regions (ERRs) worldwide have the opportunity to increase their wealth and improve the quality of life of their residents. However, a reoccurring pattern of boom and bust in these regions suggests the need for more sustainable development at the regional and community levels. This study examines one such region to discover patterns that might inform more sustainable development strategies for the future.

The Appalachia region is the birthplace of the first oil boom in the United States. Waples (2005) describes this boom, stating "the population of Titusville, Pennsylvania shot up almost overnight to approximately 10,000 people and land prices skyrocketed” (p. 16), after Col. Edwin Drake’s success in drilling for oil on August 28, 1859. Sadly, fast growth is often not sustainable. Literature suggests resource abundant economies, particularly those endowed with exhaustible resources, tend to have comparatively slower economic growth and have poor outcomes of development (Sachs \& Warner, 1995; Auty, 1993). This phenomenon is referred to as the 'natural resource curse’ by many economists. Nobel Prize winning economist Joseph Stiglitz observed, "resource-rich countries often do not pursue sustainable growth strategies. They fail to recognize that if they do not reinvest their resource wealth into productive investments above ground, they are actually becoming poorer” (Charleston Gazette, 2012).

The West Virginia Center on Budget and Policy (2012), suggests a path by enacting an economic diversification trust fund, (West Virginia Future Fund—SB 461), for turning the finite natural capital into a sustainable wealth for West Virginia. This would take a portion of the 
severance taxes from the extraction of resources and place money into a permanent trust fund.

This solution seems simple; however, the support for such change does not seem sufficient.

Although the Governor, Earl Ray Tomblin, finally signed SB 461 on March 20 ${ }^{\text {th }}$, 2014 into law, it took several years of fortitude and leadership by the state's Senate President Jeff Kessler (D-

Marshall) to promulgate the final law which had been greatly weakened by the house (Figure 1).

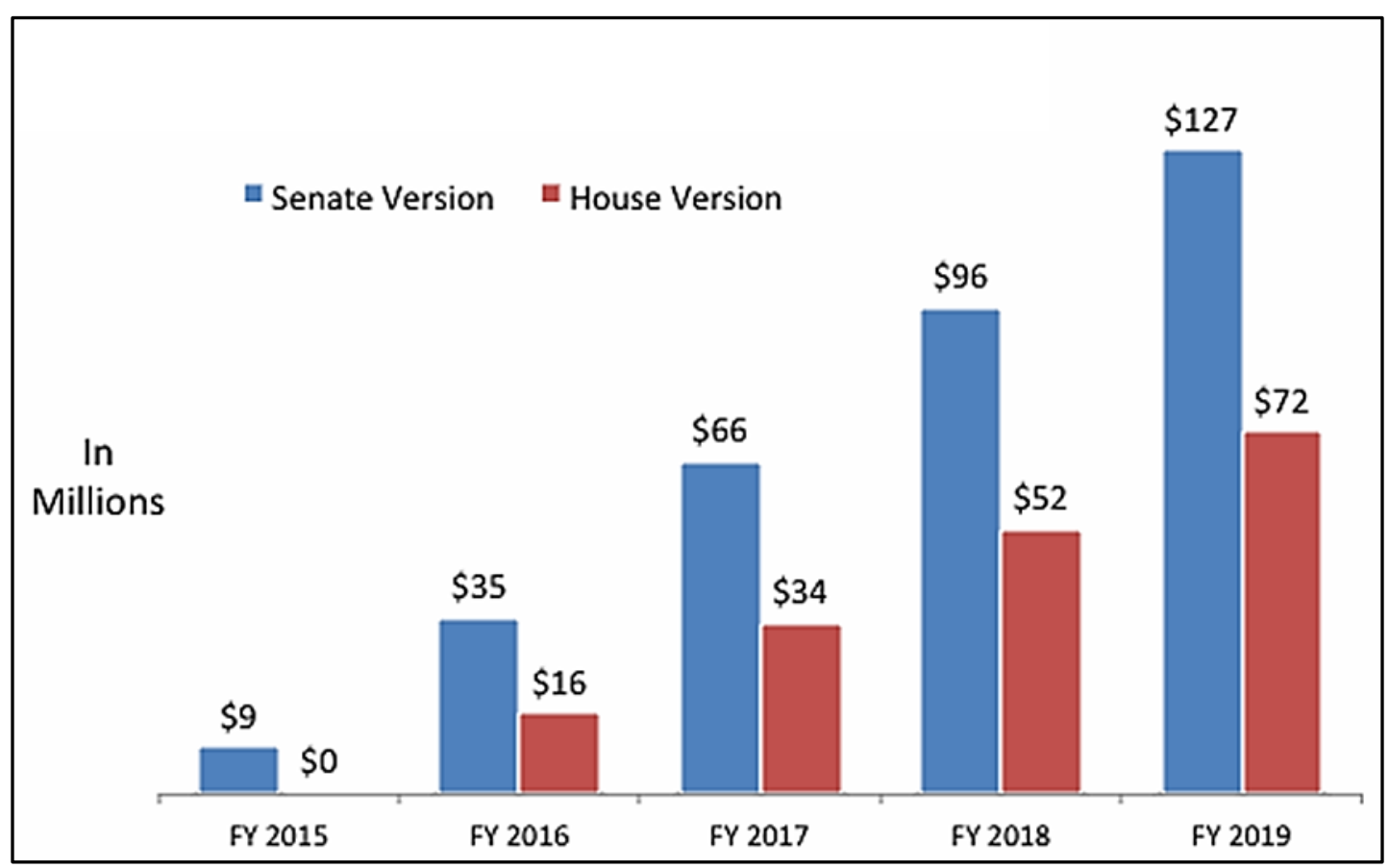

Figure 1. Estimated Difference in West Virginia Future Fund Versions by the West Virginia Department of Revenue. Note: Assumes 7.5\% annual investment rate of return. Retrieved from http://www.wvpolicy.org/what-did-the-house-do-to-the-future-fund.

Perhaps this recent change in policy is the result of increasing pressure on politicians to see more actions and protections for future generations in the aftermath of the January $9^{\text {th }}, 2014$ Elk River chemical spill—where an estimated 10,000 gallons of the coal cleaning chemical MCHM contaminated the water supply for approximately 300,000 residents. Although this tragedy is not necessarily the direct result of choosing an energy system dependent primarily on finite resources, it is but one example illustrating the indirect or unforeseen externalities associated with this type of developmental pattern. Nevertheless, the problem of the natural 
resource curse could not be more important and addressing such challenges may involve a 'bottom-up' response from the human-will to intervene at these community and regional scales.

The ERR of West Virginia exhibit a diverse and extensive prior pattern of boom and bust in timber, coal, oil, and natural gas. The effects from previous busts manifest in a decaying environment, a diminished quality of life, and a stagnant economy in the region today. Usually, money and politics drive all decisions, and energy is no exception. However, other contributing factors driving this rapid development of resources are increasing globalization, population, and technology. The latter really applies to the increasing mechanization of natural resource extraction, specifically coal, during the 1970's, and more recently in the case of Moundsville, the ability to extract unconventional shale oil and gas. What makes the most recent boom noteworthy are the technologies of hydraulic fracturing and horizontal drilling. "Although these technologies are not new, they have recently initiated the rapid production of the unconventional deposits of oil and gas in shale formations with little or no recent presence of the oil and/or gas” (Court, Jackson, \& White, p. 99, 2012).

Many stakeholders claim that the emerging gas industry will be great for everyone, resulting in increasing job growth, higher wages, cheaper energy bills, increasing energy independence, increasing wealth for property owners, and a less carbon intensive energy source (Considine, Watson, \& Blumsack, 2010; American Gas Association, 2013; HIS Global Insight, 2009; NPR, 2013; \& PBS Montana, 2012). However, other key players decry the externalities associated with the current boom in natural gas, i.e., unplanned growth resulting in increased pressure on infrastructure and the built environment; water, soil, and air contamination; increasing rent; increasing crime rates; increasing alcohol and drug use; increasing prostitution; increasing drop-out rates, and even more recently an increasing frequency of earthquakes (White, 
2012; Court, Jackson, \& White, 2012; Kinnaman, 2011; PBS Montana, 2012; Weinstein \& Partridge, 2011; USGS, 2011). These contrasting perspectives reveal only a fraction of the ‘wicked problems’ existing at the community and national levels alike.

The idea of 'wicked problems' as defined by Rittel \& Webber (1973), are the opposite of the linear 'tame problems' which most scientists and engineers focus. Tame problems are “definable and separable and may have solutions that are findable” (p. 160). With tame problems, cause and effect relationships may be generalized. "The problems (wicked problems) of governmental planning — and especially those of social or policy planning —are ill-defined; and they rely upon elusive political judgment for resolution” (Rittel \& Webber, p.160). Indeed, researchers widely agree there is no existing panacea for solving a wicked problem, nor could there ever be. "Here the aim is not to find the truth, but to improve some characteristics of the world where people live” (Rittel \& Webber, 1973, p.167). For change to occur, greater understanding must inform the human-will of the stakeholders. Only then might self-interests align in a mutual consensus between all parties.

The natural wealth flowing from the region today may or may not yield enhanced quality of living for the communities involved in the extraction of these finite resources. If previous patterns of coal production in the region are any indicator of what the future may hold for the current natural gas boom, the conclusion to this story has been written, and we may assume the development pattern of boom and bust will continue. For positive change to occur, human-will must be engaged in exercising many possible solutions for improving human well-being. There remains an option to break this vicious boom and bust cycle, and convert the natural capital into other reproducible capital forms that could produce a stream of income in the future if community leaders can summon the will to do so. 


\section{Objectives of the Study}

The purpose of this study is to explore historical choices that might be altered in some way in future designs to vanquish the natural resource curse. Currently, Moundsville (Marshall County) and the Appalachia region are in the "take off” stage (Figure 2). Before development of the finite resource begins in the 'pre-resource stage', a more proactive response to this energy system should consider this stage as a priority. A community that recognizes and integrates these different resource development stages into the planning process is more likely to have a positive post-resource outcome.

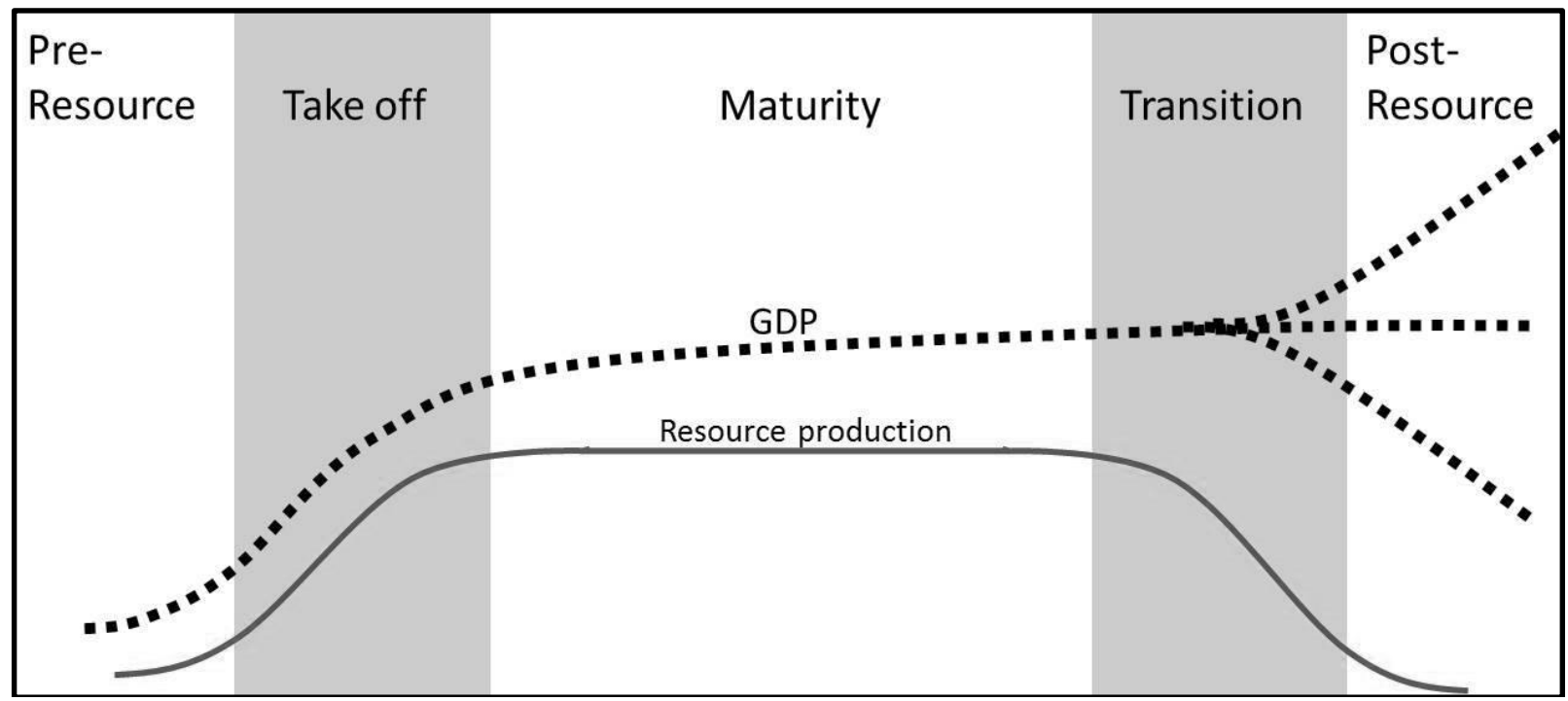

Figure 2. Stages of Resource Depletion Model. Retrieved from Ghadimi (2010).

A path to a more positive post-resource outcome is presented in Figure 3, which presents a conceptual model for engaging the planning process to extract the resources responsibly, where (N) represents the finite resources (natural capital), and ( $\mathrm{K}$ and $\mathrm{H}$ ) represents the reproducible capital forms of human capital and physical capital. “The most important development challenge for ERRs is to convert valuable, but exhaustible natural capital into reproducible capital in pursuit of sustainable economic development that is also environmentally sustainable” (Ghadimi, 2010). 


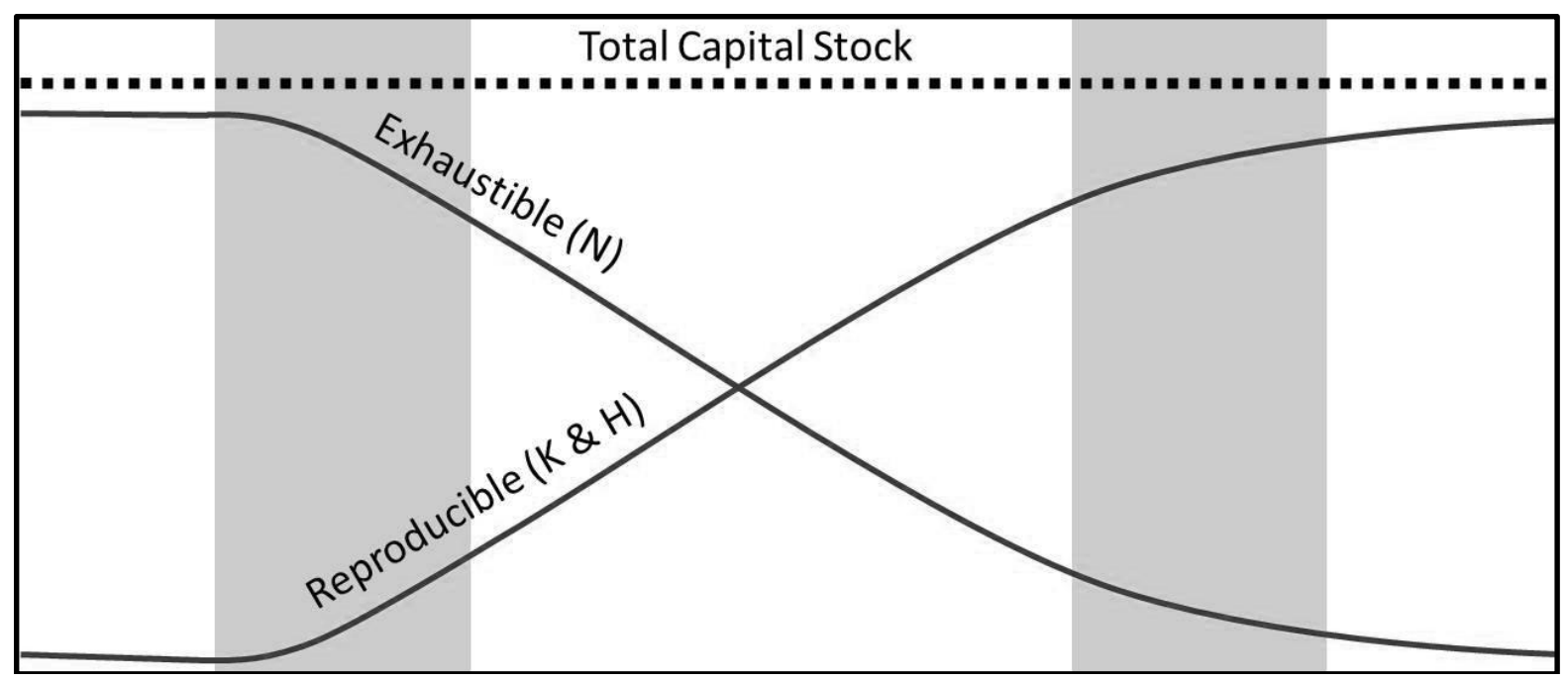

Figure 3.Total Capital Stock Conversion Model. Retrieved from Ghadimi (2010).

People living inside an ERR often feel powerless or neglected while decisions are made by people with vested interests who fail to consider what is best for a region as a whole. However, stakeholders need to engage in the design process and question how a community should transition to a sustainable economy while maintaining the environment and quality of life. This long-term thinking process is difficult for most communities which experience vast amounts of change and often lack the appropriate resources for planning and managing this growth responsibly. This can lead to rushed and negligent decisions by all stakeholders, including city, state, federal officials, as well as citizens, and producers.

Due to the lack of consistent data, indicators, and varying energy policy structures at the local level, prior research has typically analyzed development patterns at a macro scale instead of a micro scale, (community level). Perhaps a change is in order for analyzing development patterns from a more community or regional level. The West Virginia University Regional Research Institute (2013) defines an Energy Rich Region (ERR) as a type of homogeneous natural resource region located geographically in an administratively defined area containing a large endowment of energy reserves. 
The case of Moundsville inductively explores both qualitative and quantitative data, thus identifying the theoretical constructs existing when designing for sustainable development at the community level within an ERR. This is accomplished by (1) exploring sustainability through the inclusive wealth—embodied by forms of natural, physical, and human capital assets (informed via Energy Rich Region Template) and (2) linking these forms of wealth to the historical choices made at the community level (mainly from exploring seven years of city council minutes). Ultimately, this process may assist in the formation of a programming guide for communities historically dependent on natural capital. The programming guide may be a decision making tool for converting the natural capital to the more reproducible forms of human and physical capital, thus providing a more sustainable prosperous future.

\section{Case Study Background}

This phenomenon of booming gas in West Virginia is not an isolated event. Figure 4 displays the current shale plays across the United States. This boom is grabbing the attention of media and popular publications, highlighting the growing pains occurring in small rural communities as a result of the energy boom. Communities reporting such growing pains include Williston, North Dakota; communities throughout Uintah County, Utah; Lackawanna, Luzerne, Wyoming, and Wayne counties in Pennsylvania; Rock Springs and Gillette, Wyoming; Denton County, Texas; and many more.

Typically when discussing the size of a resource, the oil and natural gas industry measures natural gas by volume in cubic feet or cubic meters. The Energy Information Administration (EIA) estimates 1,161 trillion cubic feet (Tcf) of technically recoverable shale gas resources (wet and dry gas) exists in the United States. The largest portion of the US shale 
gas resources are found in the Marcellus and Utica shale formations containing 509 Tcf (44\%) throughout the Appalachia Region (EIA, June 13, 2013).

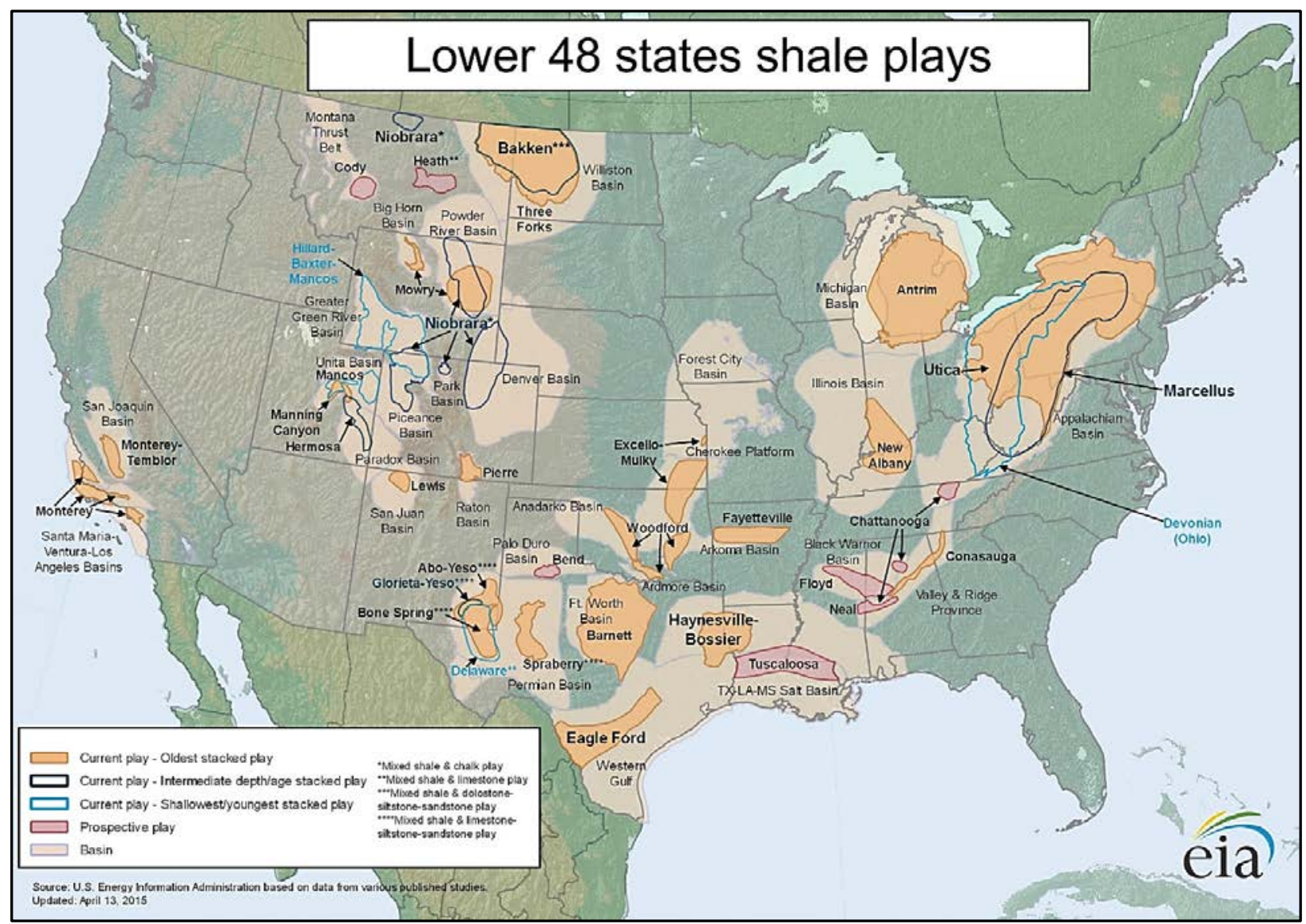

Figure 4. Shale Gas Plays, Lower 48 States. Retrieved from http://www.eia.gov/.

Currently, forty-seven out of fifty-five counties in West Virginia are seeing some type of natural gas activity in terms of permitting and completed wells. As of June 2013, there have been 2,109 completed wells and 1,360 permitted wells statewide (Figure 5). It is important to note that having a well permitted does not necessarily mean drilling will occur. In fact, with a sharp decrease in natural gas prices over the last few years (Figure 6), several companies are abandoning less profitable locations to allocate their resources to more lucrative fields further north in West Virginia. Natural gas in the northern part of the state tends to be 'wet gas' as opposed to 'dry gas'. Wet gas can be found at the same strata as oil thus providing additional 
petrol vapors including propane, butane, pentane, and heptane (Waples, 2010). These extra petrol products incentivize companies to concentrate their operations in locations rich in wet gas, especially in times of decreasing natural gas prices.

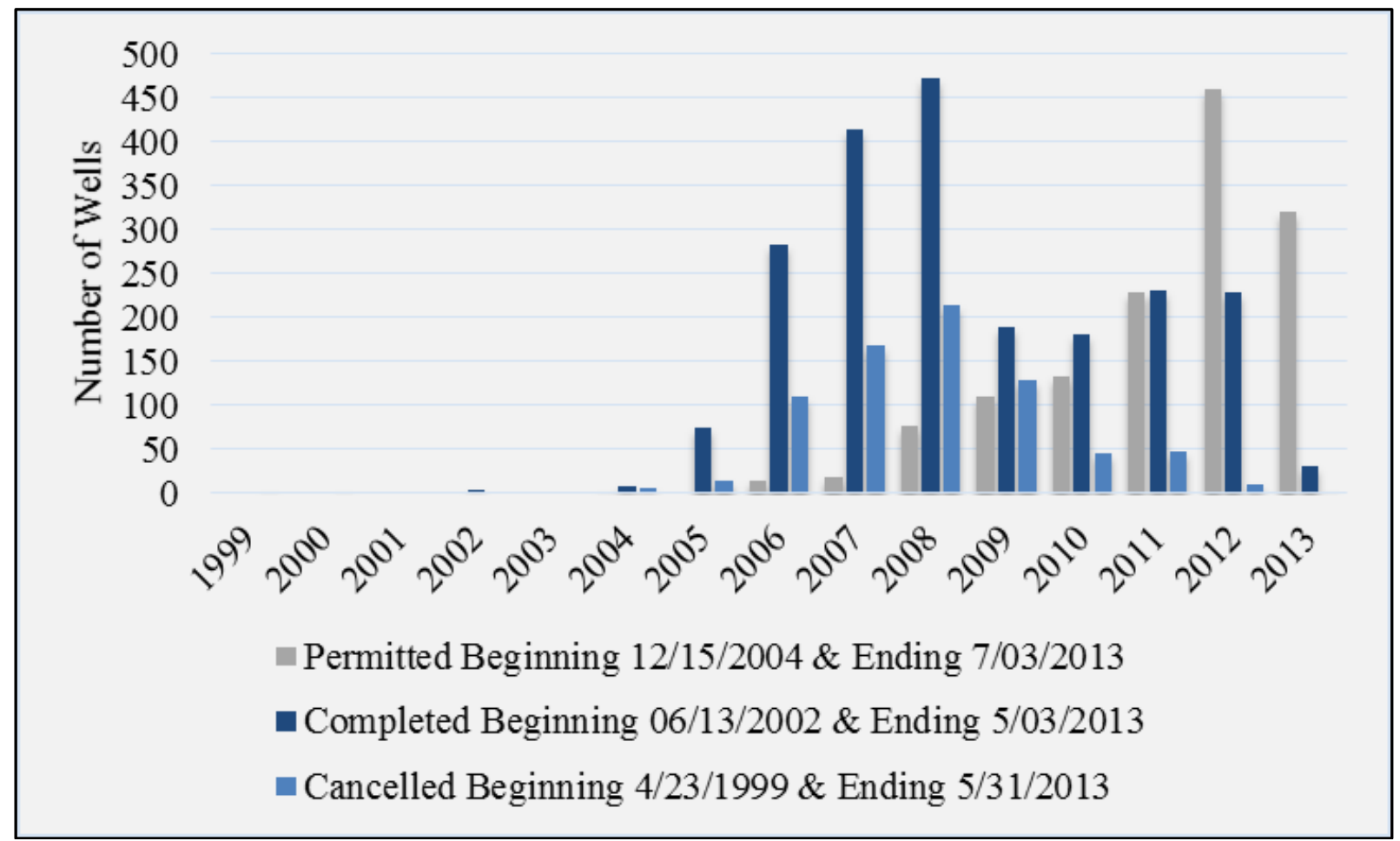

Figure 5. Historical Natural Gas Activity in West Virginia. Data retrieved from http://www.wvges.wvnet.edu. 


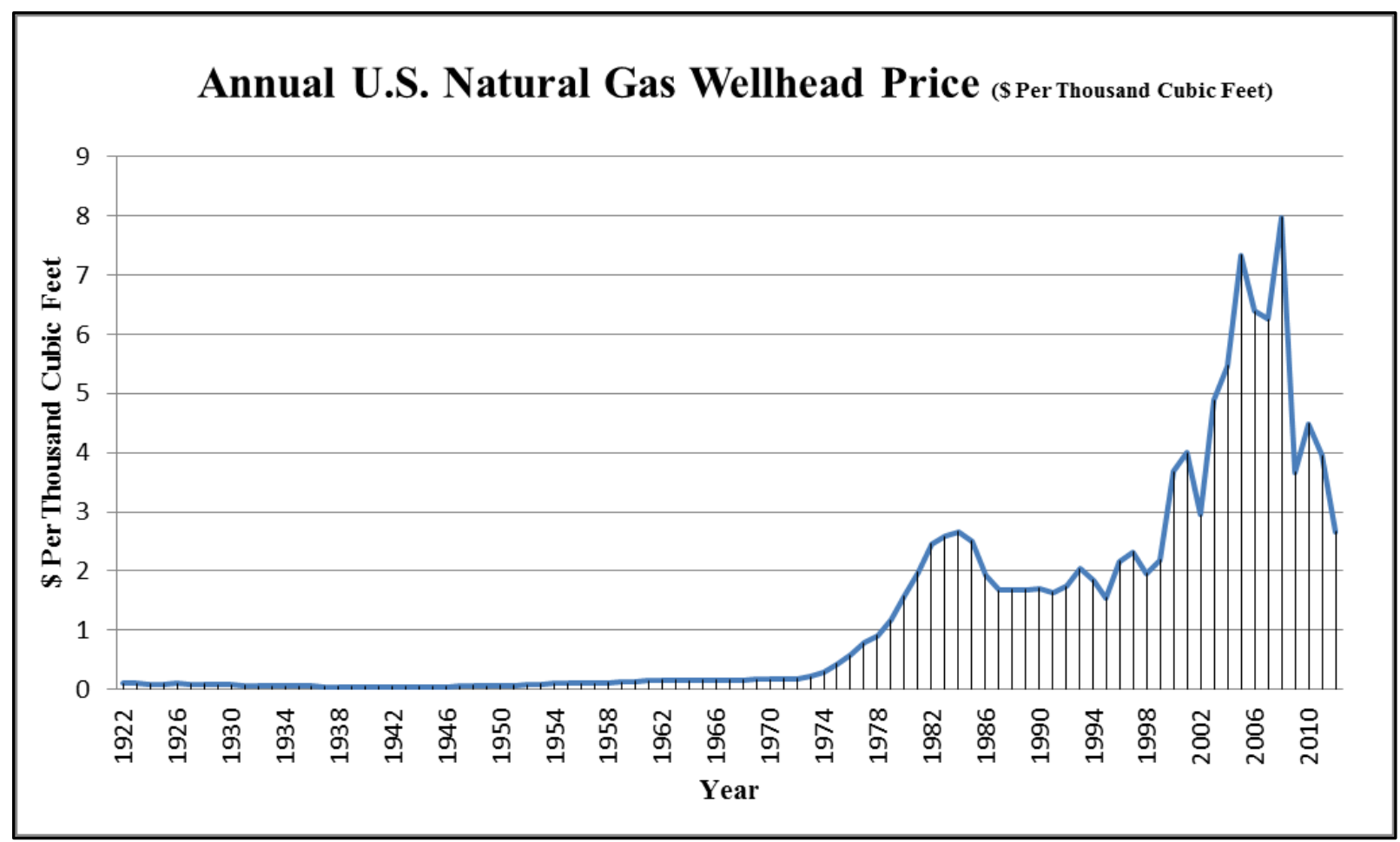

Figure 6. Annual U.S. Natural Gas Wellhead Price. Data retrieved from http://www.eia.gov/.

Although the state is booming in natural gas, as of 2012 this region at the state level had a median household income of $\$ 40,196$ ( $49^{\text {th }}$ lowest nationally) while the nation's median household income was $\$ 51,371$. This points to a seemingly common reality seen in ERRs such as West Virginia, where having high wealth in natural capital, does not necessarily translate to an increase in quality of life. This again calls for an argument to transcend from an energy systems model of boom and bust towards a more sustainable model to maintain 'total capital stock' from decreasing as previously illustrated in Figure 3.

As of 2010, Moundsville had a population of 9,318 and a median household income of only $\$ 28,496$. The poverty rate is high (21.3\%). In the case of Moundsville, this might be partially attributed to the early stages of natural resource development, prior to realization of related economic benefits. Figure 7 illustrates the amount of natural gas activity occurring throughout West Virginia as of September 2012, but focuses on Moundsville located in Marshall 
County. As of September 2012 in Marshall County, there were a total of 196 permitted and completed wells. This number increased to 242 wells in less than a year. The increase in natural gas activity will place pressure on the built environment and infrastructure such as roads, sewage, and bridges. With a potential vast increase in population, finding homes or renting apartments may become a focus by Moundsville stakeholders. If Moundsville decides to build, they could be building for a short-lived boom resulting in numerous empty structures or even incomplete development projects. This boom may be good for the short term, but the long-term implications in choosing this path is unsustainable.

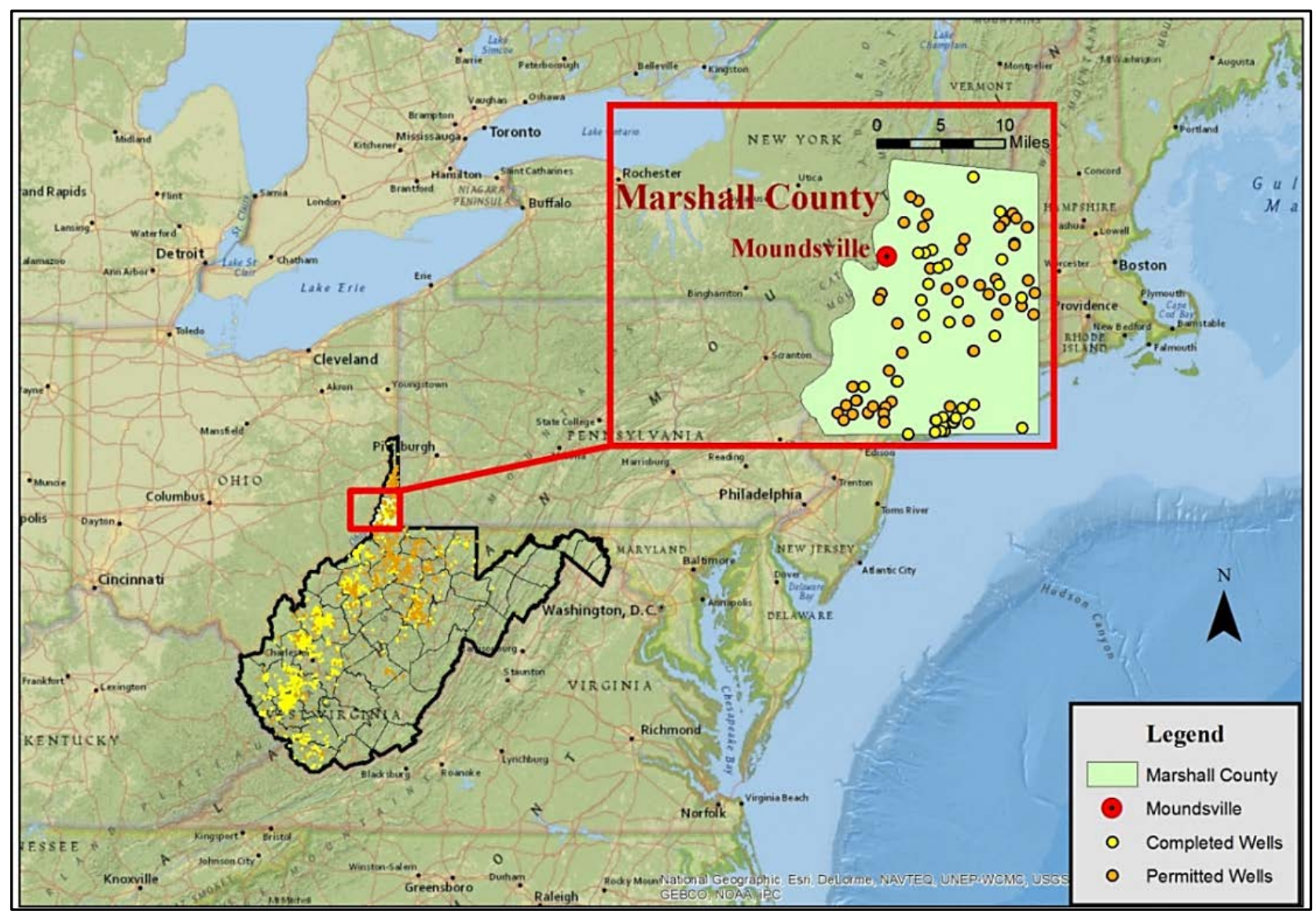

Figure 7. Natural Gas Activity in Marshall County, by Completed and Permitted Wells, Sept. 2012. Data retrieved from http://www.wvgs.wvnet.edu/. 
Table 1

Snapshot of Moundsville

\begin{tabular}{|c|c|c|c|}
\hline & US & West Virginia & Moundsville \\
\hline Population (2010) & $308,745,538$ & $1,852,994$ & 9,318 \\
\hline \multicolumn{4}{|l|}{ Population Growth (2000 - 2010) } \\
\hline Total Change & $27,323,632$ & 44,650 & -680 \\
\hline Percent Change & $9.7 \%$ & $2.5 \%$ & $-6.8 \%$ \\
\hline \multicolumn{4}{|l|}{2006 - 2010 ACS Five Year Estimates } \\
\hline Percent of Population 65 years + & $12.7 \%$ & $15.80 \%$ & $21.90 \%$ \\
\hline Percent of Population Non-White & $23.9 \%$ & $4.3 \%$ & $1.9 \%$ \\
\hline $\begin{array}{l}\text { Percent of Population Hispanic or } \\
\text { Latino }\end{array}$ & $15.7 \%$ & $1.1 \%$ & $1.0 \%$ \\
\hline Median Household Income & $\$ 51,914$ & $\$ 38,380$ & $\$ 28,496$ \\
\hline Poverty Rate (All People) & $13.8 \%$ & $17.4 \%$ & $21.3 \%$ \\
\hline $\begin{array}{l}\text { Population } 25+\text { with high school } \\
\text { degree or greater }\end{array}$ & $85.0 \%$ & $81.9 \%$ & $80.3 \%$ \\
\hline $\begin{array}{l}\text { Population } 25+\text { with bachelor's degree } \\
\text { or greater }\end{array}$ & $27.9 \%$ & $17.3 \%$ & $9.7 \%$ \\
\hline $\begin{array}{l}\text { Unemployment Rate (2006 - } 2010 \\
\text { avg.) }\end{array}$ & $7.9 \%$ & $7.1 \%$ & $12.1 \%$ \\
\hline
\end{tabular}

Data retrieved from the U.S. Census Bureau. 2006-2010 American Community Survey 5 Year Estimates. Accessed from American Fact Finder.

This region has been largely influenced by its industrial past. The impacts resulting from structural changes in the United States’ economy including the loss of traditional manufacturing jobs and prominent regional employers such as Fostoria Glass (Figure 8) and the Louis Marx Toy Company, visibly exist even today. Ironically, the Appalachia region has continuously experienced a development cycle of booms and busts since the early $19^{\text {th }}$ century including those from natural gas. A recent article in the Charleston Gazette stated, “Fostoria Glass began operations in Fostoria, Ohio, on Dec. 15, 1887, because the area was rich with cheap natural gas. But supplies dwindled quickly, and Fostoria moved operations to Moundsville in 1891 to take 
advantage of the state’s gas and coal supplies (June, 2013).” Fostoria closed its doors after increasing foreign competition in 1986, and until recently has remained as a brownfield consisting of lead, asbestos, and other harmful contaminants. When discussing the boom and bust from natural resources, it is important to include the lingering impacts left for the government and ultimately the taxpayer's responsibility to clean up from the bust. Although, the final nail in the coffin for Fostoria Glass Company may have been increasing foreign competition, Fostoria’s initial purpose for relocating in Moundsville was due to a bust in resources in Ohio and a boom in natural gas and coal in West Virginia.

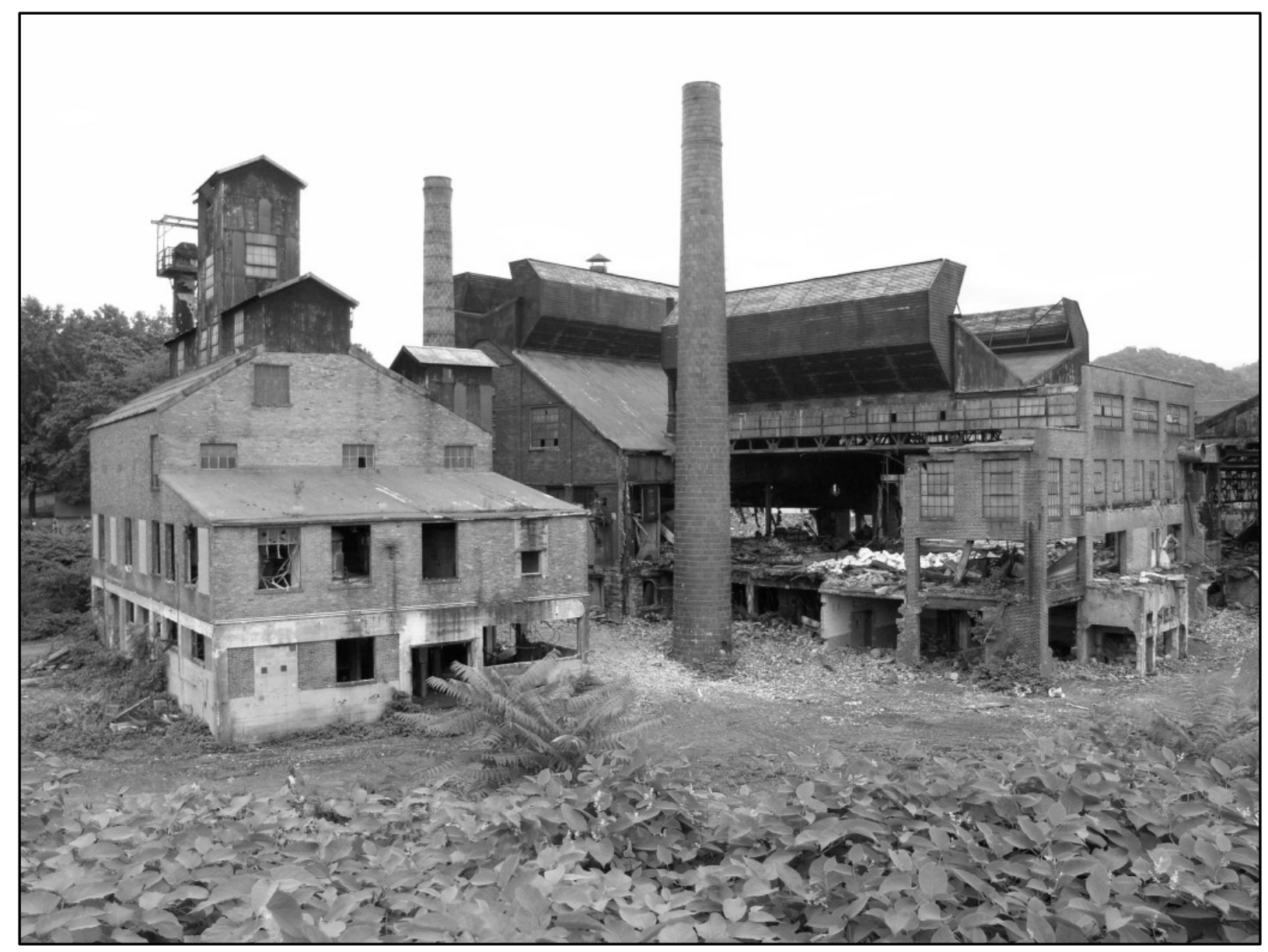

Figure 8. Fostoria Glass Company Brownfield, Moundsville, WV, July, 2006. Adapted from http://www.flickr.com/photos/14559376@N03/1569992016. 


\section{Organization of the Study}

The following is a brief description of what the reader can expect in the subsequent chapters. Chapter II reviews the literature; however, given the breadth of the related literaturean approach utilizing a delimitation process to narrow down and focus on the relevant concepts is employed. This process (Figure 9) provides the necessary knowledge and background for implementing the remainder of the case, and furthermore assists the researcher in clearly defining the case and unit of analysis (Yin, 2003). There are four main topics identified; (1) Energy Rich Regions; (2) Sustainable Development; (3) The Natural Resource Curse; and finally (4) Wicked Human Problems. Under each of these overarching topics are reviews of relevant constructs for these headings.

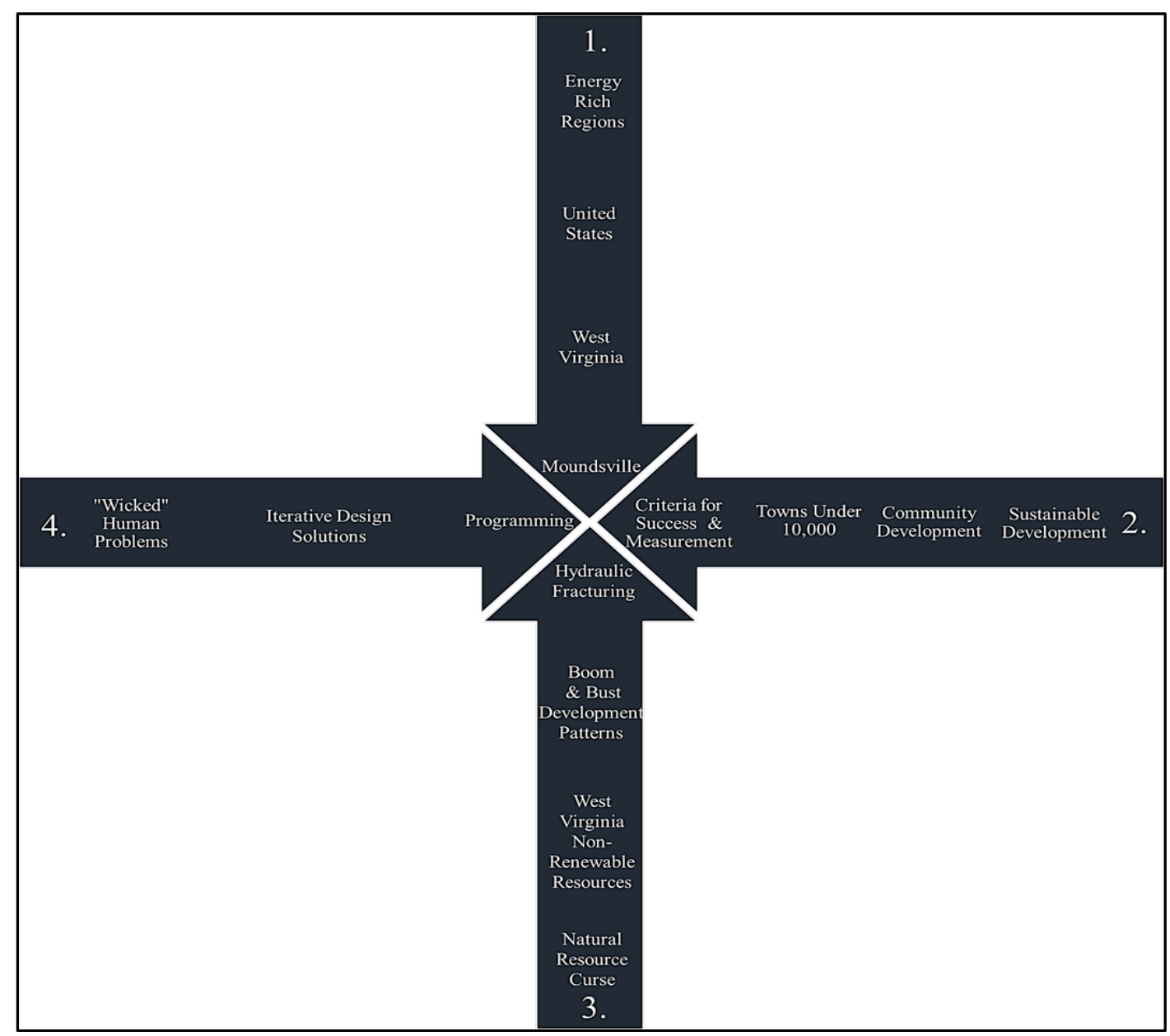

Figure 9. Delimitations Process for Case of Moundsville Literature Review. 
The following chapter, presents the methodology implemented for conducting the case which includes a case study design using a mixed methods approach. Furthermore, this chapter discusses the main tools for applying the theory at hand which are the "Energy Rich Regions Template”, the "Moundsville Knowledge Base”, and the qualitative data/coding software program MAXQDA.

The results of this coding process and analysis are found in chapter IV. Furthermore, the aggregate results from the coding process are categorized into the inclusive wealth forms of natural, physical, and human capital for linking local decision making and discussions revolving around these three capital forms. Other significant qualitative and quantitative results from knowledge base tools, e.g., ArcGis, StatsAmerica, and U.S. Census data; are also presented.

In chapter $\mathrm{V}$, the findings from conducting this case study are summarized. In addition, the implications in conducting this case and recommendations for future research are needed for providing communities practical steps forward in transforming a region to a more sustainable future.

Finally, an appendix can be found at the end which presents the open coding system utilized for analyzing the city council minutes, the Energy Rich Region Template, and photographs taken while a participant observer with the Community Design Team. 


\section{Chapter II}

\section{Review of Literature}

The following literature represents the constructs in considering sustainable development as it pertains to the Case of Moundsville. As previously introduced, a delimitations process is employed which allows the researcher to link the analysis portion of this case study back to the referenced literature. This process sets the stage for understanding the problems holistically, beginning with defining (1) Energy Rich Regions (ERRs) and briefly exploring the ERRs within the United States and in further depth—local community scales. Next, (2) sustainable development is defined from an evolving historical perspective and the criteria for successful sustainable development implementation at the community level is explored. Then a discussion on (3) the 'natural resource curse' is needed for exploring the historical constructs leading up to the current boom in natural gas. Finally, this delimitation process defines (4) 'wicked human problems' and iterative design solutions that may inform future programming recommendations for resource dependent communities in ERRs. This last topic of wicked human problems is relevant and necessary for connecting theory to action—and how theory may inform the transformation of boom and bust to a future of sustainability.

\section{Energy Rich Regions}

"An Energy Rich Region (ERR) can be thought of as a type of homogeneous natural resource region located geographically in an administratively defined area containing large endowments of energy reserves”(Regional Research Institute, 2013). Typically when discussing an ERR, one is exploring the finite resources of oil, natural gas, and coal. Ghadimi (2010) lists the advantages of using a regional approach including; (1) spatial organization of production, (2) spatial distribution of capital, (3) spatial disparities, and (4) regions are a flexible unit of analysis 
(“bottom-up regional approach to development”). The spatial unit for analyzing an ERR could be a state or province within a country or in this example, the case study examines one community within a county located in the ERR of West Virginia.

Often, the region under analysis is highly dependent on the exhaustible natural capital, although, this may not always be the case. Such regions that seem to be effectively diversifying their natural capital into more sustainable forms of capital are the states of Texas, Colorado, and California. Ghadimi (2010) states, “The most important development challenge for ERRs is to convert their valuable but exhaustible natural capital into reproducible capital in pursuit of sustainable economic development that is also environmentally sustainable.”

United States. As a whole, the United States is blessed with vast amounts of resources. In comparing internationally, the U.S. ranks $12^{\text {th }}$ in proved oil reserves, but $2^{\text {nd }}$ in oil production; $4^{\text {th }}$ in proved natural gas reserves while $1^{\text {st }}$ in production; and finally, $2^{\text {nd }}$ in coal energy production (EIA, 2013). Furthermore, the total share of natural gas production in the world is 39\% from the US, 15\% Canada, and less than 1\% from China (EIA, 2013). Unfortunately, the vast amounts of reserves and consumption of these fossil fuels comes a high output of carbon dioxide emissions where the U.S. ranks \#2 only to China as of 2013. In fact, as of 2010, the US total energy per capita was 315.9 million British Thermal Units (Btu). Compare this to the world's average total energy per capita of 74 million Btu in 2010. The EIA (2013) states the U.S. fuel mix of petroleum, natural gas, and coal has provided $87 \%$ of this nation's primary energy (Figure 10). 


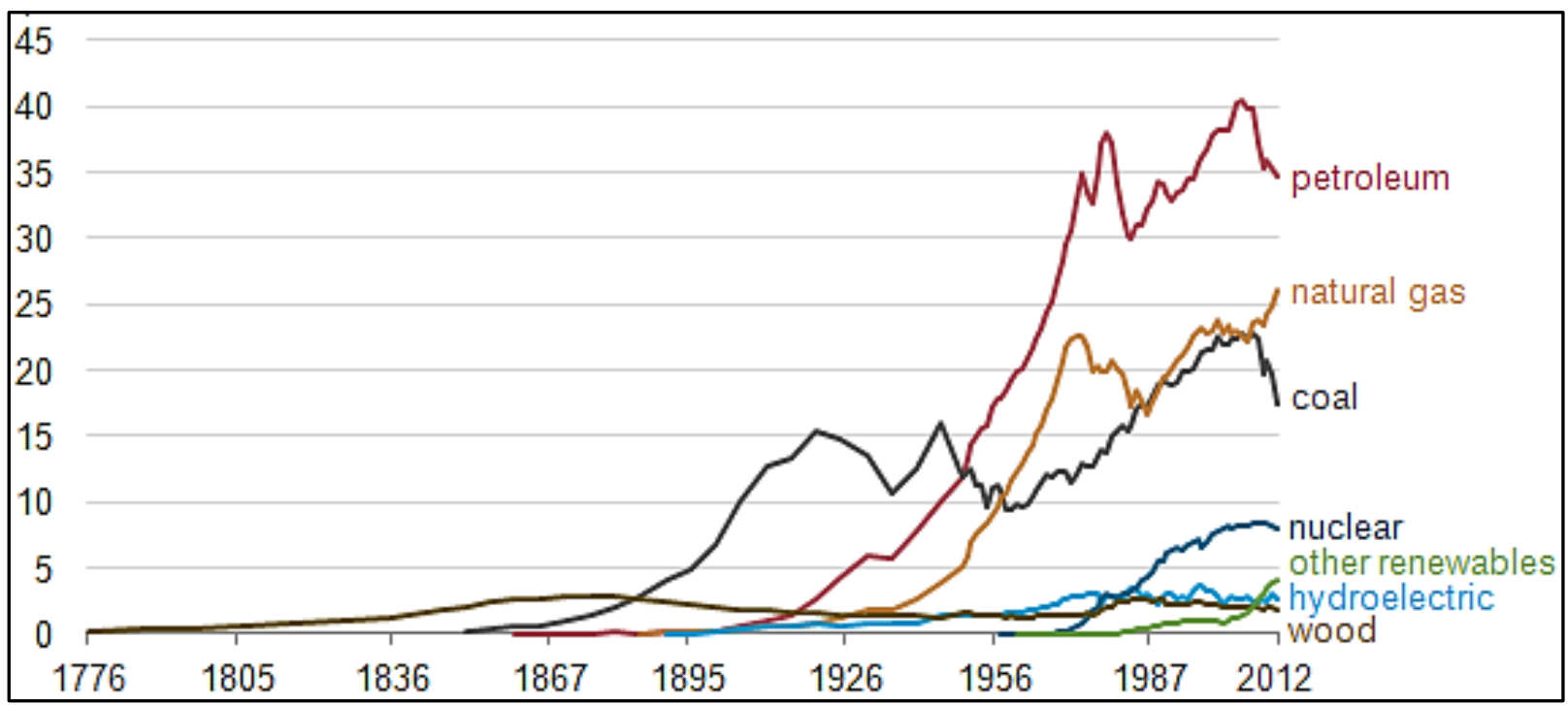

Figure 10. History of Energy Consumption in the U.S. (1776-2012). Retrieved from http://www.eia.gov/todayinenergy/.

Traditionally, when one thinks of an ERR in the U.S., the state of Texas might come to mind; however, the first oil boom began in the Appalachia state of Pennsylvania in 1859. More recently, with technological changes with horizontal drilling and hydraulic fracturing, the ERR states of Appalachia—such as Pennsylvania and West Virginia, are once again changing the energy landscape nationally and abroad. In addition, the Marcellus Shale Play, located primarily in Pennsylvania and West Virginia, became the largest proven natural gas reserves in the U.S., surpassing the Barnett Shale Play located in Texas. An EIA (2013) report stated, Pennsylvania and West Virginia alone are “expected to provide 18\% of total U.S. natural gas production for this month” (December 9, 2013). Clearly these ERR states are increasingly feeling the pressure from the nation and world to extract, transport, and provide affordable energy to the marketplace.

West Virginia. As of 2011, EIA data shows the ERR of West Virginia ranks 5th in total energy production, 2nd in coal energy production, and 10th in natural gas production within the United States. West Virginia typically generates more electricity than it consumes. In 2010, 56\% of its net electricity generation was consumed outside the state and approximately $80 \%$ of total 
energy production is exported (EIA, 2013). Currently, with the vast expansion of drilling in the Marcellus Shale, West Virginia’s position in energy production may change as long as the current boom is implemented responsibly and coal energy production remains stable. However, due to the combination of regulating mercury emissions, and most recently the potential EPA 111(d) ruling on carbon emissions regulation, the cleaner alternative energy source-natural gas, will indeed greatly impact coal's production share of energy.

Table 2

U.S. State Total Energy Production and Consumption Rankings, as of 2011

\begin{tabular}{|l|c|c|c|c|}
\hline State & $\begin{array}{c}\text { Production, U.S. } \\
\text { Share }\end{array}$ & $\begin{array}{c}\text { Production } \\
\text { Rank }\end{array}$ & $\begin{array}{c}\text { Consumption per } \\
\text { Capita, Million Btu }\end{array}$ & $\begin{array}{c}\text { Consumption per } \\
\text { Capita, Rank }\end{array}$ \\
\hline TX & 16.2 & 1 & 476 & 6 \\
\hline WY & 13.3 & 2 & 975 & 1 \\
\hline LA & 5.1 & 3 & 886 & 2 \\
\hline PA & 5 & 4 & 292 & 32 \\
\hline WV & 4.9 & 5 & 390 & 16 \\
\hline KY & 3.6 & 6 & 438 & 34 \\
\hline CO & 3.5 & 7 & 289 & 11 \\
\hline OK & 3.5 & 8 & 421 & 47 \\
\hline CA & 3.4 & 9 & 209 & 23 \\
\hline NM & 2.9 & 10 & 331 & \\
\hline
\end{tabular}

Data retrieved from http://www.eia.gov/state/.

Moundsville—Small Town Rural West Virginia. As we work through the various scales of an ERR, the complexity increases. From a more abstract perspective, the choices made at the higher regional levels manifests into a more tangible real effect at the local level. Moundsville, West Virginia is a small rural town located in the ERR of West Virginia, experiencing the top down effects of this global energy system. The community has historical significance. Due to the fertile soil and its proximity to water (Ohio River), early frontiers settled this plot of land in approximately 1771, although it was not officially incorporated until 1832. "In the center of the town is the largest conical burial mound in the Western Hemisphere- 
and one of the largest in the world” (Schramm, 2004, p.9). In explaining the historical significance, Schramm (2004) states, "It was constructed in stages between 250 and 150 B.C.E until around 1 C.E. While the Adena People were constructing the mound, Hannibal was crossing the Alps, the Great Wall of China was being built, and the Roman Empire was starting its campaign for world domination”(p. 9).

Moundsville was even a popular spot on the political trail, Schramm (2004) notes that, "Former U.S. President Harry Truman addressed attendees at the Democratic fund-raising dinner in 1956” (p.99) and the community held parades to support "Republican candidates, including Arch Moore for Congress and Cecil Underwood for governor” (Schramm, 2004, p. 98). It had been rumored by historian Peter Boyd when Moundsville was given the choice to host the state's university, West Virginia University—or the state's penitentiary, it opted for the state's penitentiary to be built in their community (Boyd, 1927). However, more recently, an author professes, "no such historical documentation exists to support the claim, and the community chose the penitentiary "because Moundsville was in close proximity to Wheeling, the state's capital at the time” (Clemins, p. 8). In addition to the state's penitentiary being located in Moundsville, the community was home to “four nationally prominent industries”(Schramm, 2004); Fostoria Glass Company, United States Stamping Company, Fokker Aircraft Factory (actually located in neighboring Glen Dale), and the Louis Marx Toy Factory (also located in neighboring Glen Dale). Schramm (2004) states, “these industries are of special interest, because three of them manufactured products that were not only unique, but which became so popular that they could be found in almost every household in America and, to some extent, worldwide. The fourth of these companies (Fokker Aircraft Company), produced a product that significantly changed the world's travel industry” (p.33). It is important to note the historical industrial past of 
Moundsville because these industries located in this community and region due to "the abundance of energy in the form of coal and gas and access to riverboats and the railroad” (Schramm, 2004, p. 61). Schramm (2004) notes that, “There were several mines being operated in the vicinity of Moundsville” (p. 66). As one can see (Figure 11), the interplay between the natural resources found throughout this community and region alike has manifested an 'energy culture' as their chosen way of life.

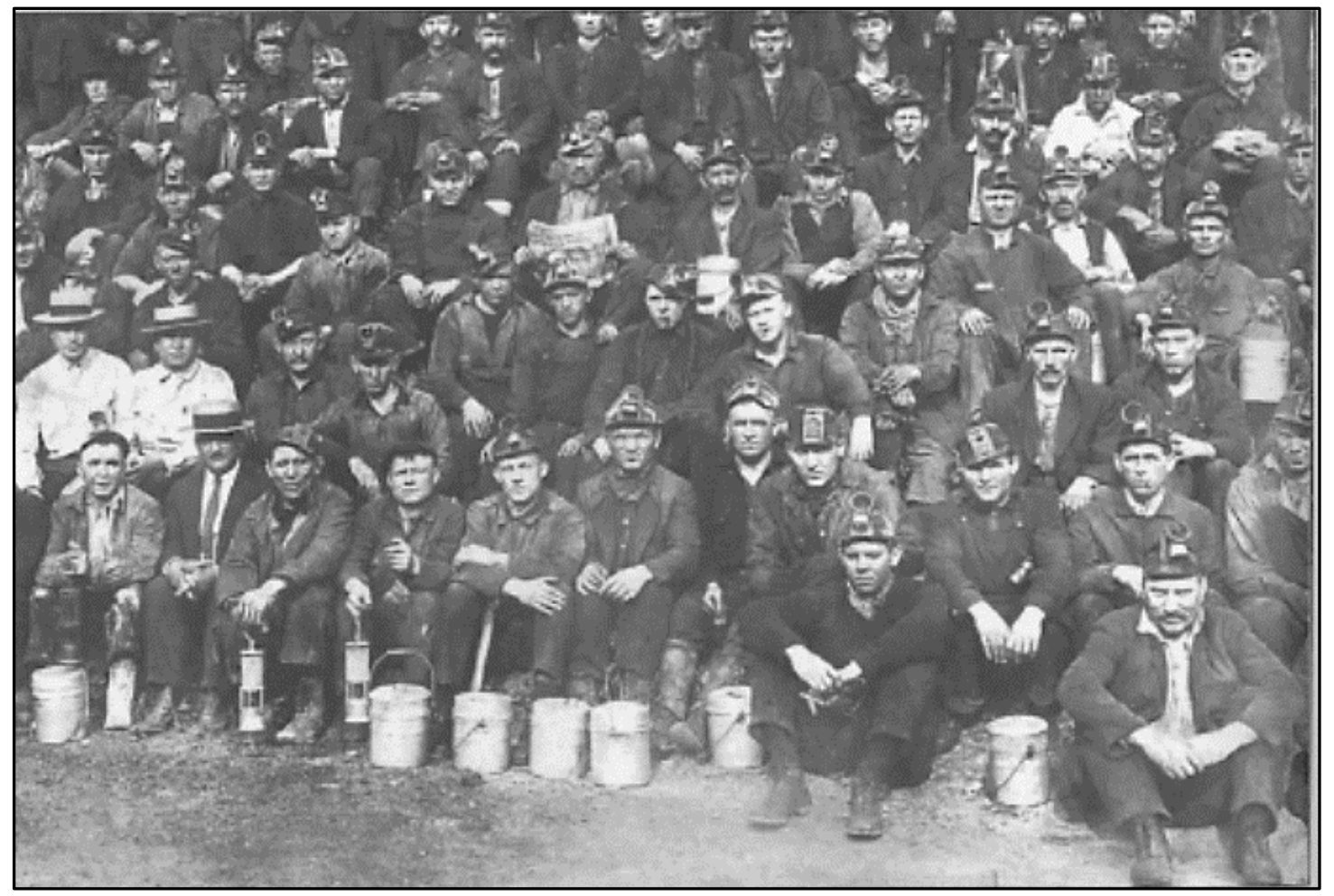

Figure 11. Miners from the First Street Mine, Approximately 1890. Retrieved from Schramm (2004).

Literature suggests Moundsville was no small town, but seemingly on its way to becoming a thriving metropolis. The following literature proposes a community's success is built on the understanding of long-term sustainable development patterns of which were seemingly not employed in the case of Moundsville. 


\section{Sustainable Development: Concepts, Theory and in Practice}

Buckminster Fuller, visionary and architect, perhaps provides the broadest definition of sustainability when he invented a game designed to promote world peace ("The World Peace Game”). The game posed this question: "How can we make the world work for 100 percent of humanity in the shortest possible time through spontaneous cooperation without ecological damage or the disadvantage of anyone?” (as cited in Meredith, 2009, p. 1). In essence, Fuller’s vision for this game is the very breath of sustainability.

Arguably, the most recognized definition of sustainable development was conceived through the Brundtland Report 1987, which states, "sustainable development meets the needs of the present without compromising the ability for future generations to meet their own needs." Understanding this broad definition, a vast amount of literature has emerged attempting to explain sustainability, however with greater complexity and focus. Many fields of academia have presented their version of the topic using a variety of examples. The most common theme used by social scientists explores sustainability through the 'three pillars scheme' of environment, economy, and society. Peering into this scheme, we find a system interdependently complex and imploring the question whether sustainability is even possible.

McDonough and Braungart (2002) defined the scope of ‘sustainable design’ across cultures and over time in their best-selling manifesto Cradle to Cradle: Remaking the Way We Make Things. Their approach to sustainable design uses a 'cradle to cradle' systems design. Furthermore, they state the current production system is largely built from a 'cradle to grave' systems design. In brief, when imagining an “assignment of designing the Industrial Revolution retrospectively”, McDonough and Braungart (2002) state, “design a system of production that creates prosperity by digging up or cutting down natural resources and then burying or burning 
them” (p.18). To this day, although there is progress in changing the production system of cradle to grave towards a system of cradle to cradle - the world still widely uses the paradigm of cradle to grave.

Human beings don't have a pollution problem; they have a design problem. If humans were to devise products, tools, furniture, homes, factories, and cities more intelligently from the start, they wouldn't even need to think in terms of waste, or contamination, or scarcity. (McDonough \& Braungart, 2013, p. 7)

Behind much of McDonough and Braungart's research is their defining of the 'The Hannover Principles’ which was publically presented in 1992. The principles state:

1. Insist on the right of humanity and nature to coexist in a healthy, supportive, diverse, and sustainable condition.

2. Recognize interdependence.

3. Respect relationships between spirit and matter.

4. Accept responsibility for the consequences of design decisions upon human well-being, the viability of natural systems, and their right to co-exist.

5. Create safe objects of long-term value.

6. Eliminate the concept of waste.

7. Rely on natural energy flows.

8. Understand the limitations of design.

9. Seek constant improvement by the sharing of knowledge. (p. 10)

Although, this code may describe a utopian vision for the future, reversing a system designed primarily dependent on fossil fuels is assuming a human civilization that is thinking long-term progress and prosperity, i.e. intergenerational equity, versus a civilization based on money and politics or short-term gains.

Within these overarching frameworks, researchers have examined issues of weak and strong sustainability as well as social dimensions and capital forms. Gowdy (1999) addresses the environmental and economic debates over the concepts of 'weak' and 'strong' sustainability. "Weak sustainability assumes substitution is possible. If one species is driven to extinction, we can use another. Strong sustainability recognizes that species are irreplaceable but implies that they have value only in an economic context” (p. 177). In addition, “strong sustainability 
recognizes the finiteness of the natural world and that there may be limits to substitution"

(Gowdy, 1999, p. 169). At first glance, it may seem like strong sustainability is the approach for sustainable development; however, it only recognizes the finiteness of the natural world in the context of economics, not social or biological contexts. As an example, Gowdy recognizes, “A complex ecosystem could be reduced to a monoculture tree farm, and as long as those trees are harvested at a low enough rate, this would be strongly sustainable in the economic sense” (Gowdy, 1999, p. 167). Gowdy suggests an alternative proposed by other economists such as Georgescu-Roegen called viability. Gowdy (1999) observes, the concept of viability recognizes that human activity and its effects on the natural world are characterized by uncertainty, irreversibility, and long-term unforeseen consequences.

Sachs (1999) discusses the social aspects of sustainability referred to as social sustainability. For such conditions to exist, it is suggested a criteria of pre-conditions must be met for sustainable development. "This becomes clear when one addresses the central question as to why so many people's needs are not being met today; moving to the analysis of economic, social, and political causes of unemployment, poverty, and social exclusion” (Sachs, p. 25).

Finally, through researching these broad perspectives White (2012) explores sustainability through capital forms, concluding:

Growth does not necessarily improve the standard of living if it compromises the quality of life and does not lead to sustainable development. This view of development includes valuing all capital that is used in producing income and calls for locally based indicators that can be used to evaluate changes in capital stocks and quality of life factors, where capital includes physical capital, public capital, natural resources, human capital, and social capital. (White, 2012, p. 114)

It is evident that defining sustainability is not without its flaws and the debate continues even today. However, the nuances of perspectives and definitions all recognize the current system is not working for humanity. The problem of living unsustainably and not considering 
future generations is man-made. To begin addressing a seemingly insurmountable paradigm, one must first design a future of balance by positioning sustainability at the fulcrum.

Sustainable Development (UN Agenda 21). A new form of governance was presented at the Rio Earth Summit in 1992 where a plan created by the United Nations was signed by 178 world leaders. The U.N. saw this as a "new form of global government known as Sustainable Development” or otherwise known as UN Agenda 21(Monolith Press, 2012).

An important element that deserves much attention for the successful implementation of sustainable development in America is found in the term 'regionalism'. In the manuscript, U.N.Agenda 21: Sustainable Development in the U.S.A. defines regionalism as:

A term used to describe cities, counties, or geographical areas that create unelected official consortiums, which often by-pass the local governments' stage of development in global economic reform and creates forces of change that affect how we might live as a society. (p. i.1, 2012)

Such an approach would require a ‘bottom-up’ response from local governments. Furthermore, NGOs and nonprofits such as the Local Governments for Sustainability (ICLEI) would become an important piece in connecting local governments voluntarily worldwide for advocating and pursuing sustainable development policies. Their mission "is to build and serve a worldwide movement of the local governments to achieve tangible improvements in global sustainability with specific focus on environmental conditions through cumulative local actions” (ICLEI, 2013).

Although sustainable development may seem on the surface as an appropriate technique for governing in America, there is much debate and even conspiracy in this new philosophy of governance. "Everything we do in our daily lives must come under increasing governmental control in order to protect the planet and maintain sustainability" including "how we build our homes, the products we use, the foods we eat, and the methods of transportation we choose” 
(Monolith Press, p. i.2, 2012). Following this observation, it is critical for government to strike a balance between protective freedoms and rights of the people in implementing such policies.

President's Council for Sustainable Development (1993-1999). In response to a seemingly positive new trend in the world's view of sustainable development, on June 29, 1993, President Clinton under Executive Order 12852 established the President’s Council on Sustainable Development (PCSD). This council presented their case in a report entitled “Sustainable America: A New Consensus for the Prosperity, Opportunity and a Healthy Environment for the Future.” Here, the PCSD suggests “Building a New Framework for a New Century," where the federal government would provide "greater flexibility and expanding the roles played by states, counties, and local communities in implementing policies and programs to address national goals” (PCSD, Ch. 4). Included in this vision, “local governments will play a key role in creating stronger communities from planning and facilitating development, to creating community partnerships, and providing leadership” (PCSD, Ch. 4).

Community Development. The biological definition of a community is: "an association of organisms of different species living together in a defined habitat with some degree of mutual interdependence” (Rocky Mountain Institute, 1998). It is important to understand community from this perspective for relating to the interdependencies, diversity (or lack of), and other constructs observed at the community scale. Realizing the previous PCSD vision for communities will require a 'bottom-up’ response from local governments and leaders. However, dwindling human capital (population and talent) and diversity may be preventing a community from engaging in sustainable development practices.

Calthorpe (2011) discusses the idea of community using the words of famed Harvard sociologist Robert Putnam who coined the term 'social capital' back in the early 1990’s. "Social 
capital consists of civic engagement, healthy community institutions, norms of mutual reciprocity, and trust” (as cited in Calthorpe, 2011). “Social capital broadens people’s sense of self from 'I' to 'we' and encourages them to work together on community problems” (Calthorpe, p. 65, 2011). Calthorpe, among many other urban designers and planners, profess that a community without social capital will fail. This could lend support for why communities through time, especially with the advent of the internet, have increasingly diminished American community’s social capital (Putnam, 2000).

Understanding how community development has changed in the U.S. through the last century reveals how isolated such places were at one time; however, this is not the case anymore. Many communities were 'truly local' in the sense "places were shielded from the full force of external influence and thus were able to sustain their more or less self-contained existence” (Chen, Orum, \& Paulsen, 2012). However, since WWII, such communities experienced a "boom like no other” and received a physical connection from government subsidies in the form of expanded infrastructure and the interstate highway system (Calthorpe, 2011). Through this transition, we chose the "suburban” model where "our national identity and international cachet were inextricably tied to cars, suburbs, and all things new” (Calthorpe, p. 26, 2011). Unfortunately, this new model calls for increasing energy-use and seemingly counterintuitivecommunities that are fragmented and disconnected.

Towns under 10,000. Knox and Mayer (2013) state, “In the United States, the fastestgrowing places in the country over the past two decades have been towns between 10,000 and 50,000 inhabitants, which together account for just over ten percent of the U.S. population”(p. 11). This massive outmigration of populations to larger cities will certainly have a long-term 
effect for the communities under a population of 10,000-even more apparent for those communities located in an ERR.

In observing the interplay between populations and the current energy system, it is important to discern between rural and urban populations and/or land because the potential effects from the energy system greatly depends on location and population size. The US Census defines 'rural' as, “a territory, population, and housing unit located outside an urban area (UA) and an urban cluster (UC)” (U.S. Census, 2013). The criterion for defining a UA is a "contiguous area consisting of densely developed territory that contains 50,000 or more people” and for a UC as a "densely developed contiguous territory that has at least 2,500 people but fewer than 50,000 people. Applying these definitions, the 2010 US Census found $19.3 \%$ of the population is rural with $80.7 \%$ being described as an urban population — and yet, over $95 \%$ of the land area is still classified as rural in the United States. Furthermore, adding even greater complexity to defining a small rural town, the Office of Management and Budget (OMB) delineates between metropolitan and micropolitan statistical area which states, “A metro area contains a core urban area of 50,000 or more population, and a micro area contains an urban core of at least 10,000 (but less than 50,000) population”.

In observing these definitions, the state of West Virginia contains 401 populated places recognized by the U.S. Census with only one city having a population over 50,000 (Charleston City). This leaves 64 places with a population greater than 2,500, but fewer than 50,000. If this study is interested in communities of less than 10,000 and greater than 2,500-this leaves 50 places in West Virginia meeting this criteria. However, these numbers although helpful in defining a rural community-the number misses the additional social dimensions such as the “interaction between land and place that is integral to understanding rural development patterns 
or the challenges associated with growth and development facing rural communities” (ICMA, p. 1 2010). One major challenge that these small communities face is not only maintaining a population, but a population that effectively commits its talents to the long-term success and vision of that community. Winkler et al. (2011) posit, “Although aging and natural decrease are certainly important issues affecting rural communities, these problems are ultimately driven by migration patterns” (Winkler, Golding, Cheng, p. 349). “Different types of natural resource dependence produce distinctive migration patterns that ultimately shape the assets that localities can engage for community development” (Winkler et al., p. 349). Additional research has shown this outmigration from these small rural towns, as described by Knox and Mayer (2013), manifests into "decades of economic and demographic stagnation” (p. 12). “Outmigration has typically accounted for a disproportionate share of the brightest, most energetic, and besteducated young people, leaving aging populations that tend to become provincial and parochial in outlook, lacking in vision and leadership” (Knox \& Mayer, 2013, p. 12). As a result, many of these communities face a rather vulnerable tipping point of decline. This phenomenon is not necessarily indicative of communities highly dependent on the energy or agricultural industries, but it also observable for small rural communities that rely solely on any named industry therefore effectively leading to a less resilient community.

Criteria for success and measurement. The PCSD profess "it is not possible today to point to a list and say, 'these communities are sustainable’”. However, in general these communities all have certain ‘characteristics in common' for moving towards a more resilient community. These common characteristics include:

(1) All people have access to educational opportunities that prepare them for jobs to support themselves and their families in a dynamic local economy that is prepared to cope with changes in the national and global economy;

(2) People are involved in making decisions that affect their lives; 
(3) Businesses, households, and government make efficient use of land, energy and other resources, allowing the area to achieve a high quality of life with minimal waste and environmental damage;

(4) These communities are healthy and secure, and provide people with clean air to breathe and safe water to drink”. (PCSD, May, 1999)

An alternative perspective on the criteria for successfully implementing sustainable development may be revealed in Flora \& Flora (2008) method called the "Community Capitals Framework” which assists in analyzing how communities work. They observe, "communities most successful in supporting healthy sustainable community and economic development paid attention to all seven types of capital: natural, cultural, human, social, political, financial and built.”

Measuring sustainability. Considering the criteria for measuring the success (or lack) of sustainability, five tools are commonly used: benefit-cost analysis; environmental assessment; risk assessment; life cycle assessment (LCA); and ecological 'footprint' analysis (Allenby, B., 1999; Costanza, R., 1991; Stavins, R., 2005; Paehlke, 1999). These measurements although helpful, tend to focus mostly on the environmental and economic dimensions of sustainability and omit the social dimensions. Stigletz et al. (2008) stated, "There is no single indicator that can capture something as complex as our society”-thus, a comprehensive measurement is needed. One possible consideration for measuring the sustainability of a society may be in using the inclusive wealth framework of human, physical, and natural capital. This was presented earlier in the capital stock conversion model which is primarily derived from the World Bank. The World Bank utilizes these capital forms framework for measuring the wealth of nations although at the country level.

Adding greater depth to this framework-Ghadimi, Harris, and Warner (2014) explore the need for measuring wealth of regions and sub-regional scales using a geospatial approach 
conceived through the inclusive wealth forms of physical, natural, and human capital. Furthermore, Ghadimi et al. (2014) provide potential indicators for measuring each of these capital forms, but also admit their list of indicators is not necessarily comprehensive or exhaustive.

There are a variety of reasons for using a capital form framework. (1) Capital forms can be comprehended as stocks of wealth and can be estimated. (2) Capital forms have the opportunity to provide a more full-cost or true-cost accounting measure. As an example, indices like GDP, do not currently fully account the depletion of natural capital or the distribution of this wealth, and yet society places great weight on using this metric for measuring economic progress. (3) Finally, the capital forms framework is more comprehensive. As previously mentioned, there is no single indicator that can capture the complexity of society, thus multiple methods, metrics, and indices should be employed. Furthermore, it should be noted there are many ancillary or more granular forms of capital that may fall into these three primary forms, e.g., creative capital and political capital would fall under human capital.

Development patterns of human capital. Human capital, broadly defined, consists of a society’s education, skills, diversity, freedoms, competence, quality of institutions, innovation etc...-much of which is, in the World Bank’s rubrics, 'intangible capital' and difficult to measure. Ghadimi et al. (2014) describe other potential indicators of human capital such as demographic structure (population and labor force), educational attainment, and talent (occupations in the creative economy).

There has been a growing trend by leading economists, urban planners, and even politicians towards agreement that human capital is the key to success of a society. Leading researchers include economist Paul Romer and urban planner Richard Florida. Romer’s ‘New 
Growth Theory’ or ‘Endogenous Growth’ focuses on a model centering on human capital, innovation, and ideas. Romer clarifies this concept of an 'object vs. idea' using a coffee cup design as an example:

The paper that makes up the cup in the coffee shop is a thing. The insight that you could design small, medium, and large cups so that they all use the same size lid-that's an idea. The critical difference is that only one person can use a given amount of paper. Ideas can be used by many people at the same time. (Bailey, 2001)

Bringing further meaning to 'human capital', Florida (2011) expounds the idea of 'creative class' and states it is largely compiled of occupations from architecture, engineering, social science, computer science and programming, and arts and entertainment among many other occupations. "It has grown from roughly 5-10\% of the workforce at the turn of the century to roughly a third or more of the workforce in the advanced economies by the early 21st century” (Florida et al., 2011).

Development patterns of physical capital. Physical capital generally, is anything manmade, i.e. roads, buildings, infrastructure etc... Emery \& Flora (2006) refer to physical capital as 'built capital' and define it as the infrastructure supporting the six capital forms presented in their ‘community capital framework’ (natural, financial, political, social, human, \& cultural). Ghadimi et al. (2014) examine potential indicators for measuring physical capital including residential and non-residential buildings (housing, commercial buildings, schools and colleges, churches, bridges, correctional institutions, and state government buildings), and infrastructure (transportation and communication structures, urban and regional sewer and utility networks, etc.).

The PCSD (1999) state, “Society’s investments should aim to create places that people want and can sustain. The built environment is a critical factor in shaping the quality of life, 
accessibility, environmental burden, and unique character of a community, which contributes to a sense of place" (Ch. 4). Thus if the priority for sustainable development is to "create places that people want and can sustain”, then sustainable design should inform the development patterns of physical capital. Ultimately, what shapes the physical capital are the local building codes and zoning ordinances. If a community is to be resilient, then "making efficient use of existing infrastructure, energy, materials, and land” through important components of sustainable design such as 'location efficiency’ (PCSD, 1999, Ch. 4). “Zoning ordinances that allow for mixed-use development, such as having a store, apartment building, and school on the same block, can give people easy access to a range of facilities and the ability to walk to obtain goods and services” (PCSD, 1999, Ch. 4). Furthermore, this reduces the need for motorized vehicles, thus decreasing traffic congestion and pollution from mobile sources.

The importance of physical capital cannot be underestimated because the built environment improves the quality of life with access to amenities like electricity and shelter, and is the tool and vessel for connecting human capital.

Development patterns of natural capital. Finally, we come to understand the vital role that all life depends—natural capital. Hardin (1968) uses the example of a herdsmen's decision to add an additional cow to a pasture that can be shared by all in explaining the concept 'Tragedy of the Commons'. "Ruin is the destination toward which all men rush, each pursuing his own best interest in a society that believes in the freedom of the commons. Freedom of the commons brings ruin to all” (Hardin, 1968). To Hardin’s point, it is rational for every herdsman to continue adding more cows to this pasture in order to increase their individual incomes (self-interests). Eventually this pasture reaches its carrying capacity and everyone loses. Similar to this story, the 
'Tragedy of the Commons’ has and is occurring in present day when extracting natural resources such as natural gas and oil (Figures 12 \&13).

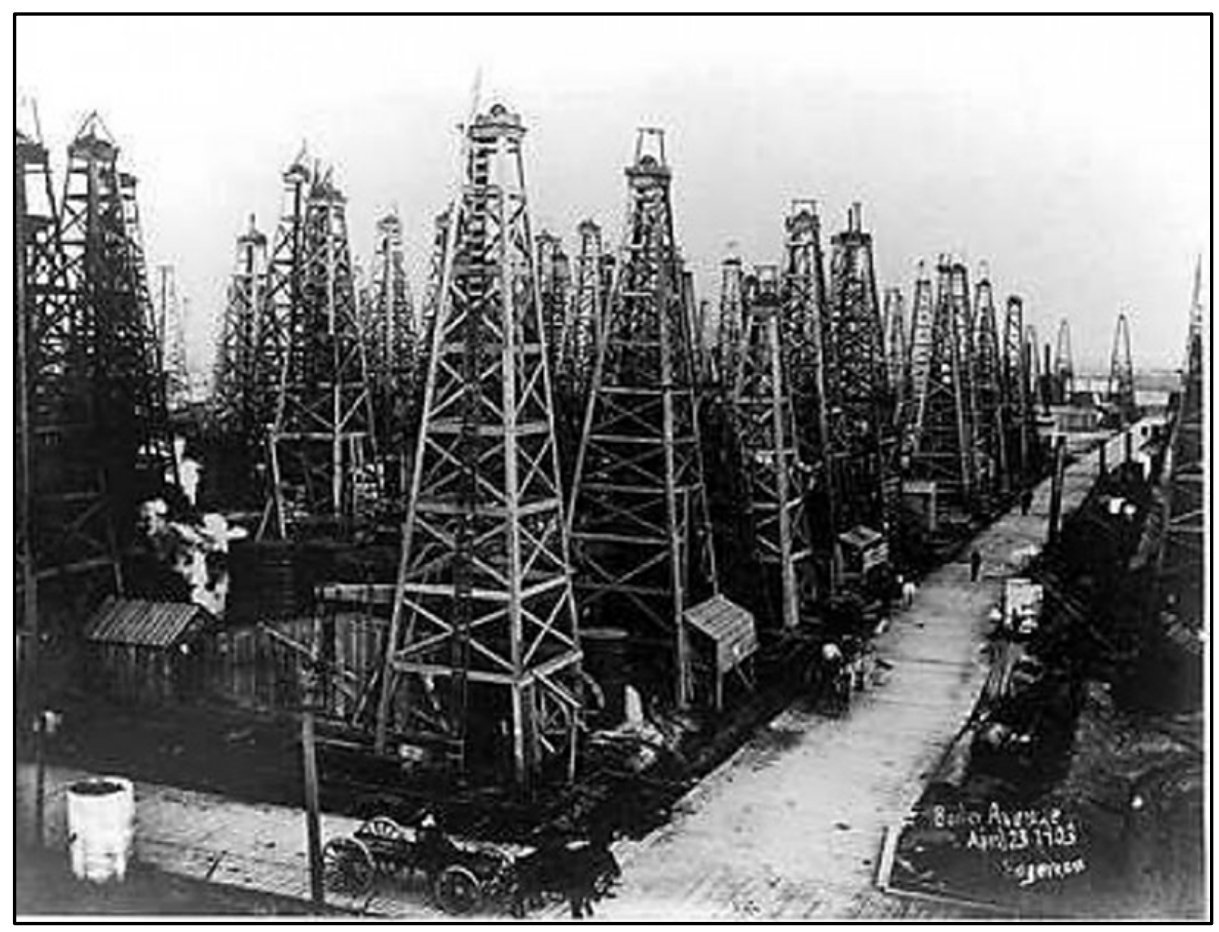

Figure 12. Rapid and Uncontrolled Oil Production in the Past, Spindletop, TX, 1903. Retrieved from Bosselman, Eisen, Rossi, Spence, \& Weaver (2010).

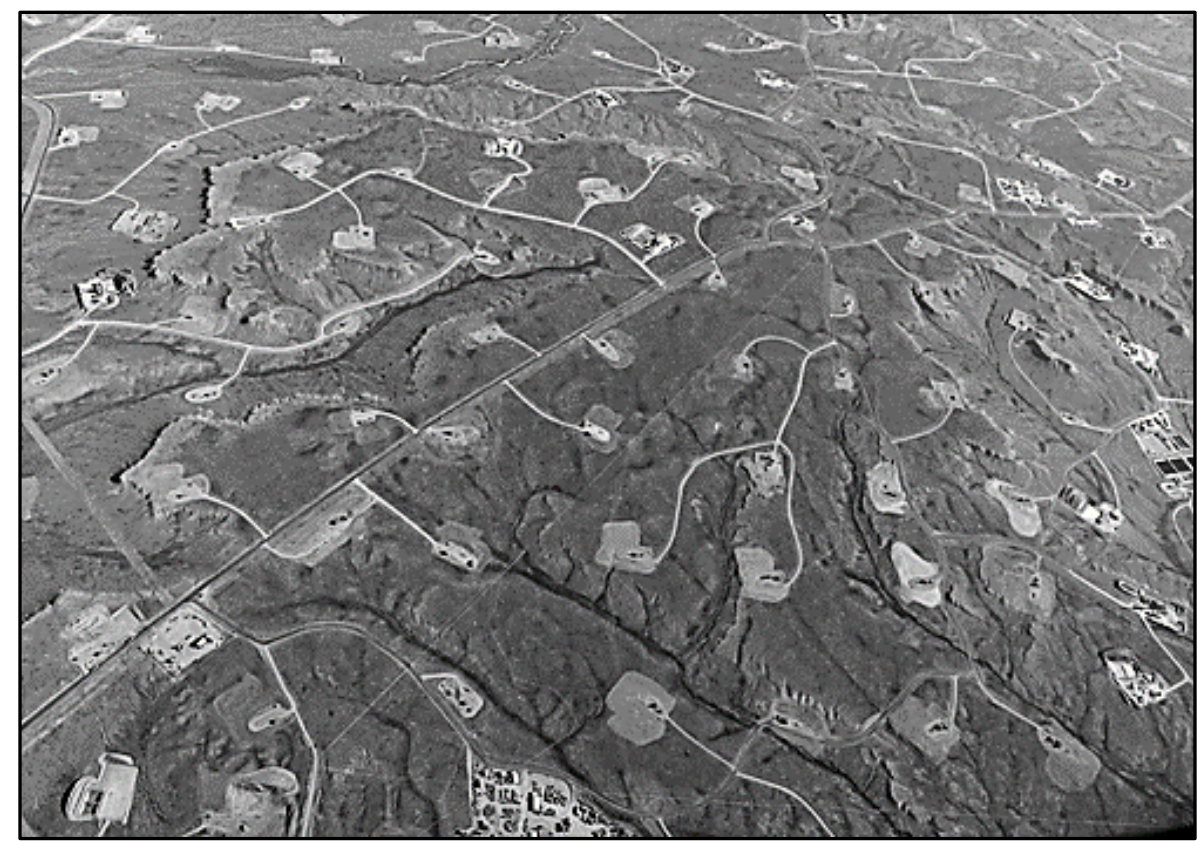

Figure 13. Rapid and Uncontrolled Gas Production Present Day, Public Land, Western Wyoming, 2011. Retrieved from The Wilderness Society (2012). 
Adding greater breadth and focus to defining natural capital can be revealed by other leading researchers. “Any resource or environmental asset is a form of 'natural capital,' whose value to society is by definition equal to the amortized value of future benefits that can be derived from use of the asset” (Clark, 1991). Emery \& C. Flora (2006) define natural capital from a less economic perspective as "those assets that abide in a particular location, including weather, geographic isolation, natural resources, amenities, and natural beauty” (p.20). Ghadimi et al. (2014) add potential indicators for natural capital in referencing their case of West Virginia —fossil fuel energy resources such as coal stock and ecosystem services. Arif (2012), compares the natural capital assets and amenities between Vermont and West Virginia and observes, “Policy-makers must fully account for the economic benefits of natural landscapes-including those that stem from intangible use and enjoyment, and include this as a central part of the economic development equation” (Arif, p. 2). These natural and recreational amenities have shown to affect a region's ability to attract the talented and innovative thinkers of tomorrow. For this reason, one may consider the long-term effects the energy industry has on the landscape. Once the decision is made to transform the natural capital into either human or physical capital forms - a debt is left for future generations which cannot be reversed but must be compensated by sufficient increases in physical or human capital.

\section{The Natural Resource Curse}

Weinstein \& Partridge (2011) state, “Generally, economists find that energy development is associated with small or even negative long-run impacts” (p. 1). Moreover, Weinstein \& Partridge, give several examples of ERR's that are plagued by the 'natural resource curse' including Louisiana and West Virginia, and countries like Venezuela and Nigeria. Literature suggests resource abundant economies have comparatively slower economic growth and have 
poor outcomes of development (Sachs \& Warner, 1995; Auty, 1993). Other researchers have explored the relationships and suggested reasons for slow economic growth among natural resource abundant countries; e.g., corruption (Ades \& Di Tella, 1999), “natural resource abundant countries overshooting their steady-state in terms of consumption and production” (Rodriguez \& Sachs, 1999), the lack of human capital (Gylfason et. al, 1999),“resource abundance renders the export sectors uncompetitive and that as a consequence never pursued export-led growth” (Sachs \& Warner 2001), and finally political and institutional driven explanations ( Mehlum et. al., 2006). Much of the literature on the natural resource curse is based on economic models and lacks the insight needed to explore the additional dimensions seen impacting people and their communities resulting from the natural resource curse. There is more behind the natural resource curse than economics which cannot simply be explained by economic models. By digging deeper, the constructs of the natural resource curse may be revealed, e.g., culture, historical decision-making, and lack of human capital etc...

West Virginia's history of non-renewable resources. West Virginia and its counterparts of Appalachia have a rich historical ‘energy culture’. However, as indicated by Ghadimi et al. (2014), “West Virginia reveals the irony of 'a rich region with poor people’ typical of many rural energy rich regions” (Ch. 8, p. 116). Traditionally, West Virginia is seen as a 'coal state' and has remained an integral part of the West Virginia economy since its discovery in Boone County in 1742 (WVGES, 2013). In fact, from 1920 to 1950 the coal mining industry employed more people and invested more capital than any other industries in the state combined (Casto, 2004). Waples (2005) states, “West Virginia historians assert that the 'Little Mountain State’ may have initiated the domestic petroleum industry months earlier in 1859 when the Rathbone Brothers began boring a salt well at Burning Springs Run near Little Kanawha” (p. 
110). Salt water wells (for tanning leather) were dug by hand as early as 1779 in West Virginia and these brine wells would often lead to the ignition of natural gas during this time period. However, natural gas was seen as a waste product resulting from this process and was not considered to be a potential nor viable resource. Human innovation, technology, and the marketplace would need to evolve before natural gas could be considered a practical resource.

In referencing Figure 14, a few notable historical natural gas achievements in West Virginia include; (1) the discovery of oil and gas by salt well drillers in 1806, (2) new drilling methods invented by William Morris in Kanawha County in 1831, (3) the discovery of the Big Moses well in 1894 which was the first 100 million cubic foot well in the U.S., (4) the formation of Hope Natural Gas Company by Standard Oil interests in 1898, and (5) the discovery of 1930 Oriskany sand natural gas play which leads to a boom in West Virginia, central Pennsylvania, and New York. More recently, the increasing abundance of natural gas could be added to this historical energy continuum due to the expansion of hydraulic fracturing throughout the Marcellus and Utica shale formations. 


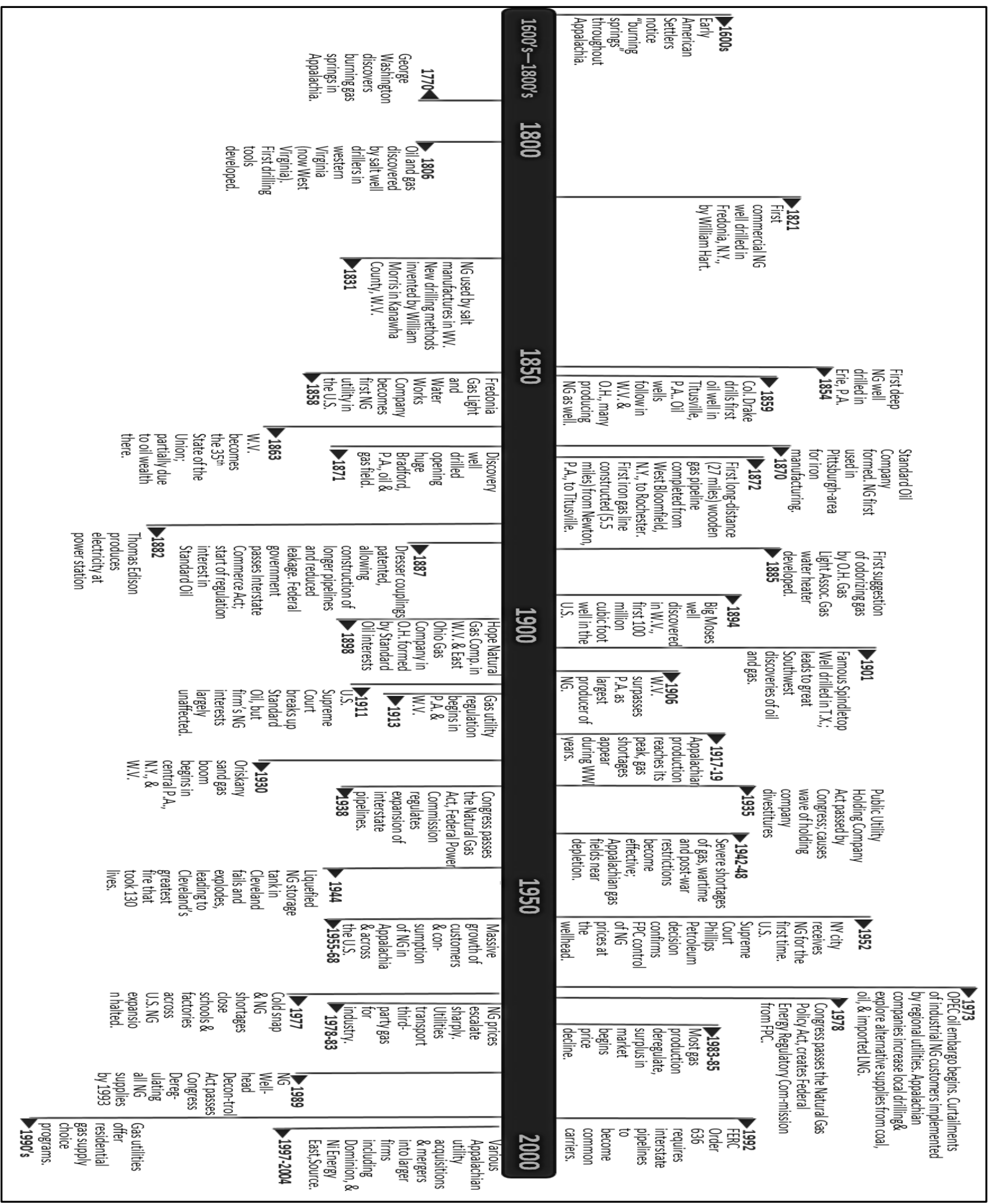

Figure 14. Appalachian Natural Gas History Timeline. Altered and adapted from Waples (2005). 
Linking Moundsville’s boom and bust development patterns to theory. Generally, typing the key words 'boom and bust' into a search field results with voluminous amounts of literature dedicated to market bubbles and or the economy. This play on words is typically for understanding the dynamics of neo-classical economics, which is essentially modern day economics where supply and demand are based on the assumptions that people will make rational choices to maximize utility and profit. Perhaps a change is in order for exploring boom and bust patterns in the context of sustainable development. Currently, the topic of boom and bust lacks the qualitative data needed to understand the wicked problems concerning the interplay of energy and sustainable development at the local level. A few alternative theories of boom and bust are professed in the following:

One such alternative theory of boom and bust development patterns can be traced back in readings examining ancient civilizations that collapsed such as the Western Roman Empire, Mayan, and Chacoan civilizations. Well known anthropologists Joseph Tainter (1988) explores such civilizations connecting the overwhelming evidence and the common principal concepts leading towards collapse:

Human societies are problem-solving organizations; sociopolitical systems require energy for their maintenance; increased complexity carries with it increased costs per capita; and finally, investment in sociopolitical complexity as a problem-solving response often reaches a point of declining marginal returns. (Tainter, p. 194)

This theory of diminishing returns as it relates to the underpinnings of society raises many issues concerning sustainability. Society reaches a point where increasing complexity calls for increasing investments. This adds a perspective to this idea of a boom and bust pattern, although occurring over a period of centuries, where Tainter states, "What is perhaps most intriguing in the evolution of human societies is the regularity with which the pattern of increasing complexity 
is interrupted by collapse-by episodes when societies change rapidly to a lower level of complexity”. Tainter's idea of diminishing returns as it applies to society may relate to what we are observing in a short-term boom and bust development pattern. To clarify, the social phenomena of 'increasing complexity' over time is a type of 'boom' and the 'collapse' may be considered a type of 'bust'.

Another alternative theory of boom and bust may be revealed in the social phenomena of ‘efficacy-performance spirals’ (Lindsley, Brass, \& Thomas, 1995). These spirals are defined as, “deviation-amplifying loops in which the positive, cyclic relationship between perceived efficacy and performance builds upon itself” (Lindsley et al., 1995). Lindsley et al. (1995) apply this concept through multilevel perspectives including individuals, groups, and organizations. "The advantage of a multilevel perspective lies in the recognition that individuals, groups, and organizations are not separate conceptual categories, but parts of a whole, each affecting and being affected by the other” (p. 647). "When considered over time, the cyclical nature of the efficacy-performance relationship suggests three possible patterns: (1) self-correcting cycle, (2) upward spiral, and finally, (3) downward spiral” (p. 650). Lindsley et al. (1995) suggest fifteen propositions for guiding future research by identifying the "factors affecting the occurrence, continuation, and stopping of spiral”. Linsley et al. (1995) posit the results from an upward spiral ending (bust), is “more problematic” than halting an upward spiral (boom) stating:

Because the causes of success during an upward spiral may not be well understood, actors are left without the tools to correct for the initial failure once the spiral is stopped. Thus, it is likely that the initial failure after stopping an upward spiral will be followed by another failure. Without the ability to selfcorrect, upward spirals are more likely to be followed by downward spirals than by self-correcting cycles. (pp. 661-662)

Concluding, Linsley et al. (1995) theorize, “The cyclic nature of the efficacy-performance relationship may be a critical link to understanding and managing the factors that have an impact 
on the performance of individuals, groups, and organizations, and thus, their self-regulation” (p. 672).

The last alternative theory in exploring boom and bust seems the most relevant in exploring Moundsville in the context of natural resource dependent communities and the socioeconomic influences typically associated in such communities. Malamud (1984) explores this perspective in his thesis and later in his book called "Boomtown Communities”. Malamud builds upon previous boomtown research, and provides a comprehensive perspective on the rise and fall of communities throughout the world dependent on mining especially in gold, coal, and oil.

Malamud (1984) calls this rise and fall phenomenon, 'boomtown syndrome’. Much of Malamud's work is built upon the work of Gilmore (1976) who created the "Gilmore's Problem Triangle” which represents the boomtown model seen in Figure 15.

Gilmore's boomtown model includes the local services (public) and the basic (private) sectors. They are in equilibrium before the boom. The community's residents determine the extent to which they are willing to pay for local services and therefore, the quality of those services. When the energy boom suddenly begins to pump vast sums of money into the basic service sector, the town's population must increase in order to fill the new jobs and the local service sector must expand as rapidly to keep the town's quality of life intact. (Malamud, 1984, p. 6)

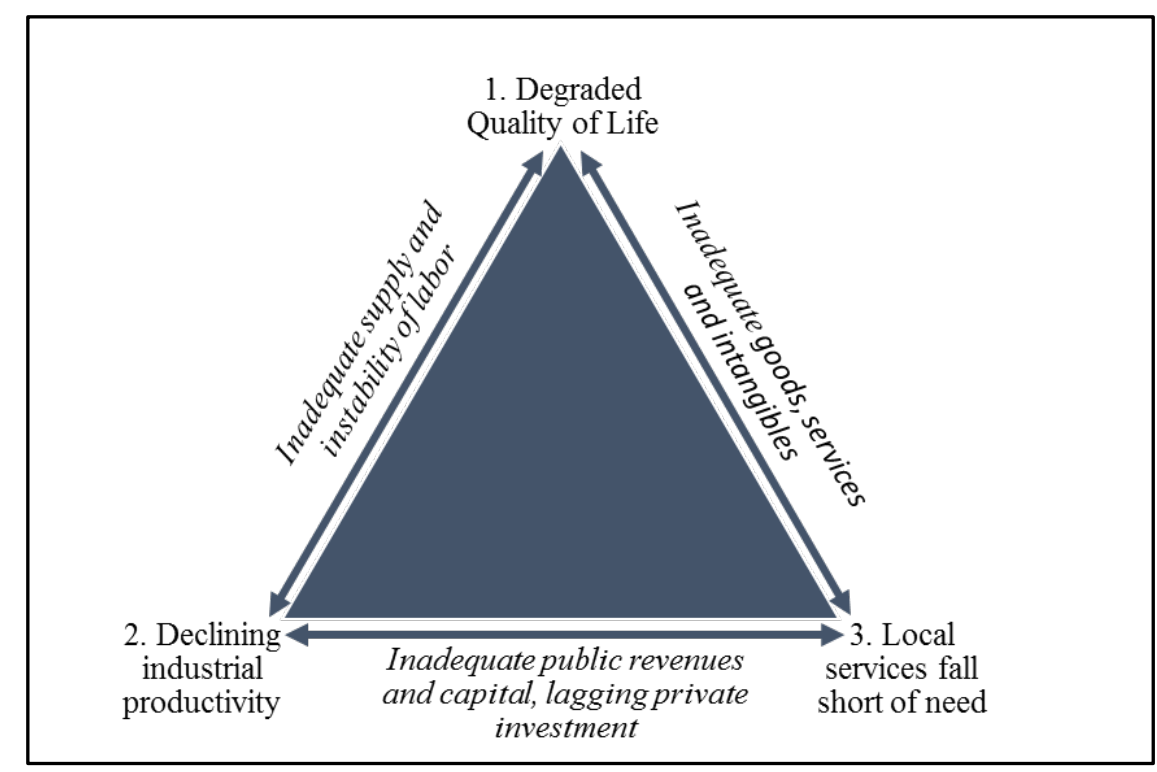

Figure 15. Gilmore’s Problem Triangle. Adapted from Gilmore (1976). 
Gilmore (1976) and other researchers consider an impacted community a boomtown if it experiences a population growth rate exceeding 15\% annually. In addition, Gilmore states there are four main phases of attitudes for the local elected officials and citizens of the community dealing with the effects of boomtown growth; (1) enthusiasm, (2) uncertainty, (3) near panic, and (4) adaptation. Unlike Gilmore, Malamud believes towns, states, and industry should play the major role in managing boomtown communities instead of the federal government.

Freudenberg (1992), discusses the social impacts on resource dependent communities in over specializing or what he calls ‘overadaptation’. Freudenberg states, “While overadaptation may happen in response to virtually any activity, the potential is particularly evident for rural communities that become heavily dependent on, or too closely adapted to, large scale extractive industries” (p. 10). Furthermore, Freudenberg lists four ‘noteworthy’ factors leading to overadaptation which are (1) anticipation of duration of development; (2) ongoing duration of prosperity; (3) level of prosperity; and (4) rate of evolution and specialization. The interplay of these factors results in "industries effectively taking over local economies—absorbing and committing local resources and potentially reshaping the entire physical and social environment of the area, in a fashion that can leave it less able to adapt to other opportunities in the future” (p.16).

Hydraulic fracturing. To be more informed of the constructs occurring in the previous described theories, it is important have a general understanding of latest technological phenomenon and hydraulic fracturing processes taking place throughout Moundsville and Marshall County. In referencing Freudenberg's theory of “overadapting”, it is understandable how this theory may be conceived when observing the vast resources and investments needed for hydraulic fracturing. The investments added to the finite energy system are not only made by 
private oil and gas companies; but by community, county, and state decision makers—which sends ripples of impacts throughout the environment, society, and the economy.

The EIA defines hydraulic fracturing as, "a technique in which water, chemicals, and sand are pumped into a well to unlock the hydrocarbons trapped in shale formations by opening cracks in the rock and allowing natural gas to flow from the shale into the well” (EIA, 2012). This process is commonly used in conjunction with horizontal drilling allowing access to deposits that were once not possible. Although the technology of hydraulic fracturing has been around commercially since the 1940 's, it was not until recently at the beginning of the $21^{\text {st }}$ century that horizontal drilling combined with hydraulic fracturing became prevalent and economically viable.

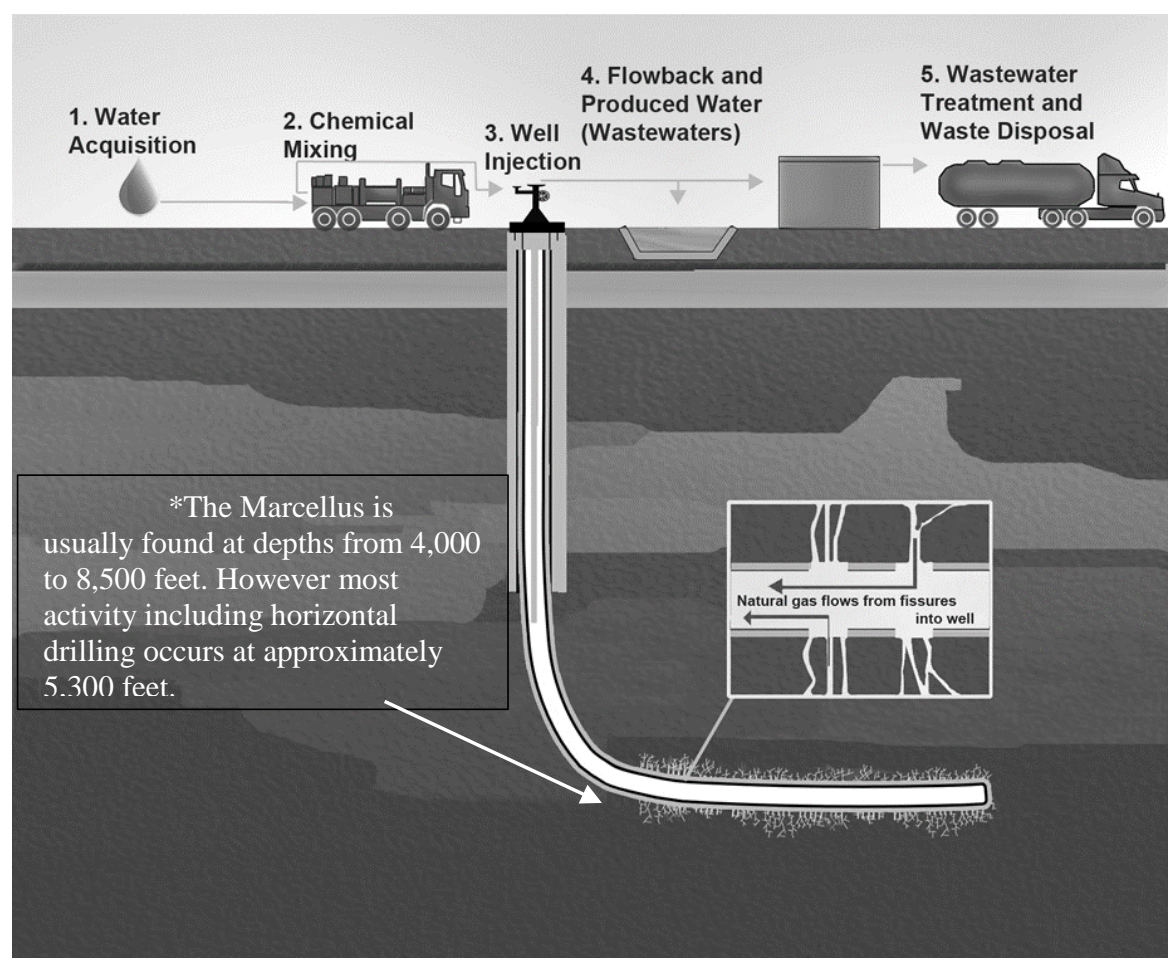

Figure 16. The Process of Hydraulic Fracturing. Altered image with caption and arrow. Adapted from http://www2.epa.gov/hfstudy/hydraulic-fracturing-water-cycle.

In the West Virginia Department of Environmental Protection (WVDEP) report entitled State of the Environment $4^{\text {th }}$ edition, the agency states, "Since January 1, 2006, the Department 
of Environmental Protection has issued over 1,200 permits for Marcellus drilling” (2011). The earliest documented natural gas well drilled into the Marcellus shale play was in Roane County permitted in November, 2001 and completed in June, 2002 (WVGES).

Before any drilling begins, a gas lease is signed between the landowner and the energy company granting exploration and development rights to subsurface oil and gas deposits. Landowners are encouraged to have these contracts reviewed before signing over both surface access and mineral rights.

The regulation of oil and gas wells are primarily overseen by the state and therefore rules, taxing/fee schemes, setbacks etc... vary from state to state. The Department of Environmental Protection (DEP) Office of Oil and Gas are responsible for establishing rules and regulating the construction of every well in West Virginia. The DEP reviews all gas well permit applications and conduct inspections before, during, and post construction. Furthermore, gas companies are required to post a bond with DEP to guarantee plugging and or reclamation of the site. Although these rules and regulations primarily focus on protecting water quality and preventing pollution, drilling companies currently are not subject to the same environmental standards, such as the Clean Water Act, or the Safe Drinking Water Act since the Energy Bill of 2005 was passed by Congress—commonly referred to as the 'Halliburton Loophole'.

The process for drilling a gas well can range from 2-8 weeks, but can be even longer. During this time, depending on the well size and location, a substantial amount of land may be disturbed. If the well is productive, the well head, meters, and tanks will remain on site. If it is not productive, the well will need to be plugged in accordance with state regulations.

Although there may be many economical and even environmental benefits proclaimed by the oil and gas industry, there is a movement of concerned citizens decrying some of the 
externalities associated with choosing this path, which highlights the concept of "wicked problems”.

\section{“Wicked” Human Problems}

Rittel and Webber remain the most influential in exploring wicked problems. Through their work they have characterized such problems as 'ill-defined' or 'unstructured' in contrast to 'tame' or 'well-structured' problems that engineers and scientists typically encounter. Rittel and Webber (1973) state, “There is no definitive formulation of a wicked problem” and "the information needed to understand the problem depends upon one’s idea for solving it” (p. 161). Therefore, "The formulation of the wicked problem is the problem" (p. 161). "Because there are no criteria for sufficient understanding and because there are no ends to the causal chains that link interacting open systems,” the designer can only try to find a better solution.

Ritchey (2013) builds upon the work of Rittel \& Webber’s definition states, “Above all, wicked problems won't keep still: they are sets of complex, interacting issues evolving in a dynamic social context. Often, new forms of wicked problems emerge as a result of trying to understand and treat one of them” (p. 2).

Banathy (1996) claims, "In the design world of wicked problems, the aim is not to find the truth but to design systems that enhance human betterment and improve human quality” (p. 31). As cited in Banathy (1996), Rittel and Webber state, "Solutions to design problems are good or bad. They are not true or false. Judgments of 'goodness of fit' of the solution may vary depending on people’s interest, values, and perspectives” (p. 31).

Cherry (1999), discusses the wicked problems from the context of an architectural programmer stating, "While we may not be able to solve them, the awareness can make our activities more effective.” Furthermore, Cherry professes that a wicked problem is dependent on 
the value system of the individual. "Wicked problems have a right solution only from one point of view. When an individual is in a decision-making role, the solution that seems right to that individual will be the one that supports his or her value system.”

Iterative design solutions. One such solution for designers in exploring wicked problems is through the 'systemic' (Banathy, 1996) approach. Contrast this from the 'systematic' approach that is linear or one-directional, the systemic approach "relates to the dynamic interaction of parts from which the integrity of wholeness of the system emerges” but it also “recognizes the unique nature of each and every system” (Banathy, 1996, p. 57). Academia points out society continually tries to solve wicked problems using the same technique they apply to linear problems or tame problems and expect one right and one wrong answer. Banathy (1996), states, “This paradigm is not applicable to open social systems. They often approach problems in social systems the way scientists do their tame problems” (p. 30).

Banathy (1996) states, “Design is a creative, disciplined, and decision-oriented inquiry, carried out in iterative cycles” (p. 16).

The design process is not linear, sequential, or systematic. Design manifests dynamic interaction between feedback and feed forward, reflection and creation, and divergence and convergence. This dynamic process goes on until we develop confidence in the viability of one of the solution alternatives. (Banathy, 1996, p. 17)

Banathy (1996) states from a systems perspective there are two general solutions when we realize that something is not working and we need to engage in the design process. (1) A solution that focuses on "changing within the system, which are accomplished by adjustment or improvement”. (2) In the case where "our purposes are not viable anymore and our system is out of sync with the environment in which it is embedded" then there is the option to change the whole system. In this case, the feedback received calls for change to the system as a whole. 
When changing a system, an iterative design solution process is employed that is "guided by self-regulation” (Banathy, 1996, p. 49).

Programming. "Programming is the systematic search involving gathering, organizing, and interpreting information that is relevant to a project” (Dickinson \& Marsden, 2009, p. 1213). Pena \& Focke (1969) present a five step format for programmers in the context of these determinants which includes; (1) establish goals, (2) collect and analyze, (3) uncover and test concepts, (4) determine needs, and (5) state the problem. This systematic format is in wide use even today and may be provide direction for communities looking to change their community from a boom and bust development pattern towards a more sustainable development pattern.

The results in conducting this literature review process, reveals a broad range of theories, definitions, and potential constructs that should be considered for improving an energy system based on finite resources towards a system of regional diversity. Although the constructs discussed here may not be an exhaustive list of topics, it does reveal the complexity involved in considering the theory of sustaining total capital stock by converting natural capital to the more sustainable forms of human and physical capital. Furthermore, although this conversion model is an ideal option for reaching a more sustainable system, it is not without its limitations which is revealed under the overarching topic of wicked problems. To this point, before a community may even consider moving towards a more sustainable system, the human-will to change must be informed by an iterative design process which may improve post-resource outcomes. Finally, in linking theory to action, a first practical step may be the development of a programming guide for communities ready for change. 


\section{Chapter III}

\section{Methodology and Procedure}

The following presents the research design chosen for the case study of Moundsville. This case study design utilizes the recommended practices for case study design by Yin (2003). Furthermore, to add a greater consistency to the case study design, a mixed methods approach is employed combining both qualitative and quantitative data for enabling a more comprehensive and systematic case study. One such tool for supporting the analysis process includes the ERR Template-which not only informs the relevant theory at hand, but also informs the open coding process of the city council minutes and exploring the Moundsville Knowledge Base with the support of the qualitative data software program MAXQDA. The participant observation activities involving the Community Design Team are discussed which enhances the researcher's ability to gain first-hand accounts of the community’s sense of place, challenges they are facing, and to observe any effects the oil and natural gas industry may be having on the community. Finally, the researcher addresses strategies for maintaining reliability and credibility throughout the case.

\section{Case Study Design}

Yin (2003) defines a case study as "an empirical inquiry that investigates a contemporary phenomenon within a real-life context, especially when the boundaries between phenomenon and context are not clearly evident” (p. 13), where: “(1) how or why questions are being posed and (2) the investigator has little control over events” (p. 1). It is common to conduct a case study in the fields of psychology, sociology, political science, social work, business, and community planning. 
Yin (2003) suggests five components in conducting a case study. These components include (1) research questions, (2) propositions, (3) unit of analysis, (4) logic linking the data to the propositions, and (5) criteria for interpreting the findings. The following is a brief definition of these components and their descriptions as applicable to the case study of Moundsville.

Study questions. The case study strategy is most likely to be appropriate for how and why questions, so the initial task is to clarify precisely the nature of the researcher's study questions in this regard. Initially, case study questions are deductively produced. The main overarching question-is the natural capital (natural gas) being converted effectively to the reproducible forms of human and physical capitals to avoid the boom and bust cycles of the past? If not, then what are the barriers hindering progress towards a more sustainable and diversified future? Accompanying this overarching question are many granular questions which can be explored in the ERR Template (Appendix A) which contains potential indicators for exploring sustainability through natural, human and physical capital.

Propositions. A proposition is something that should be examined within the scope of the study. The more a study contains specific propositions, the more it will stay within feasible limits. West Virginia is a typical ERR exhibiting a diverse and extensive prior development pattern of boom and bust in timber, coal, oil, and in recent years, a boom in natural gas. This development pattern suggests the need for implementing sustainable development strategies. The theory put forth is - if the natural capital is converted effectively or responsibly-then a community historically dependent on natural resources, should be able to transition to a more sustainable and prosperous community. 
Unit of analysis. Yin (2003) states this should be more concrete and not as abstract. The researcher needs to define a specific, real-life case to represent the abstraction and define specific time boundaries for the beginning and ending of the case. This case study explores briefly the past development patterns to gain a further understanding of the 'energy culture' in the region, and in greater detail the pre-boom and most current boom in natural gas specific to Moundsville, in Marshall County. It should be noted, that although the focus is on the community of Moundsville, much of the actual process for hydraulic fracturing occurs throughout Marshall County and therefore should be included in observing the development patterns where data may not be as accessible at the community scale. The time period of most interest will be pre-boom data from approximately 2006-2008 and the current boom continuing from 2008 to 2012 .

Logic linking the data to the propositions. Yin (2003) suggests several options for logic linking the data to the propositions: (1) pattern matching (describe several potential patterns, then compare the case study data to the patterns and see which is closer); (2) explanation building (mostly occurs in narrative form which stipulates a presumed set of causal links that are similar to an independent variable in a rival explanation); (3) time-series analysis (asking how and why questions about relationships over time which could be simple, complex, or chronological); (4) logic models (events are observed in repeated cause and effect patterns); and (5) cross-case synthesis (contain at least two cases, but are each treated as separate cases while observing cross-case patterns). The case of Moundsville primarily utilizes a time series analysis through chronological order. However, pattern matching and explanation building were utilized in combination with a time series analysis method for linking data to the proposition. 
Criteria for interpreting the findings. The most common technique in case studies is to identify and address rival explanations for the findings, but alternative techniques could include addressing the most significant aspect of the case study and/or utilizing prior expert knowledge. The criteria for interpreting the findings in the case of Moundsville is first addressing the most significant aspect of the case and then utilizing previous expert knowledge from the literature review delimitations process. The theories and observations from previous research as discussed during the literature review_-may provide insight to the rival or similar explanations.

\section{Procedure}

A mixed methods approach (Creswell, 2003) to this case study design is employed by combining qualitative and quantitative data for investigating the research inquiries. Figure 17 illustrates the process for applying a mixed methods approach created uniquely for this case study. Creswell (2003) states there are three general strategies to a mixed methods approach; sequential, concurrent, and transformative procedures (p. 16). For the purpose in conducting the case of Moundsville, a transformative procedure will be employed. A transformative procedure is defined as:

A procedure, in which the researcher uses a theoretical lens as an overarching perspective within a design that contains both quantitative and qualitative data. This lens provides a framework for topics of interest, methods for collecting data, and outcomes or changes anticipated by the study. (Creswell, 2003, p. 16) 


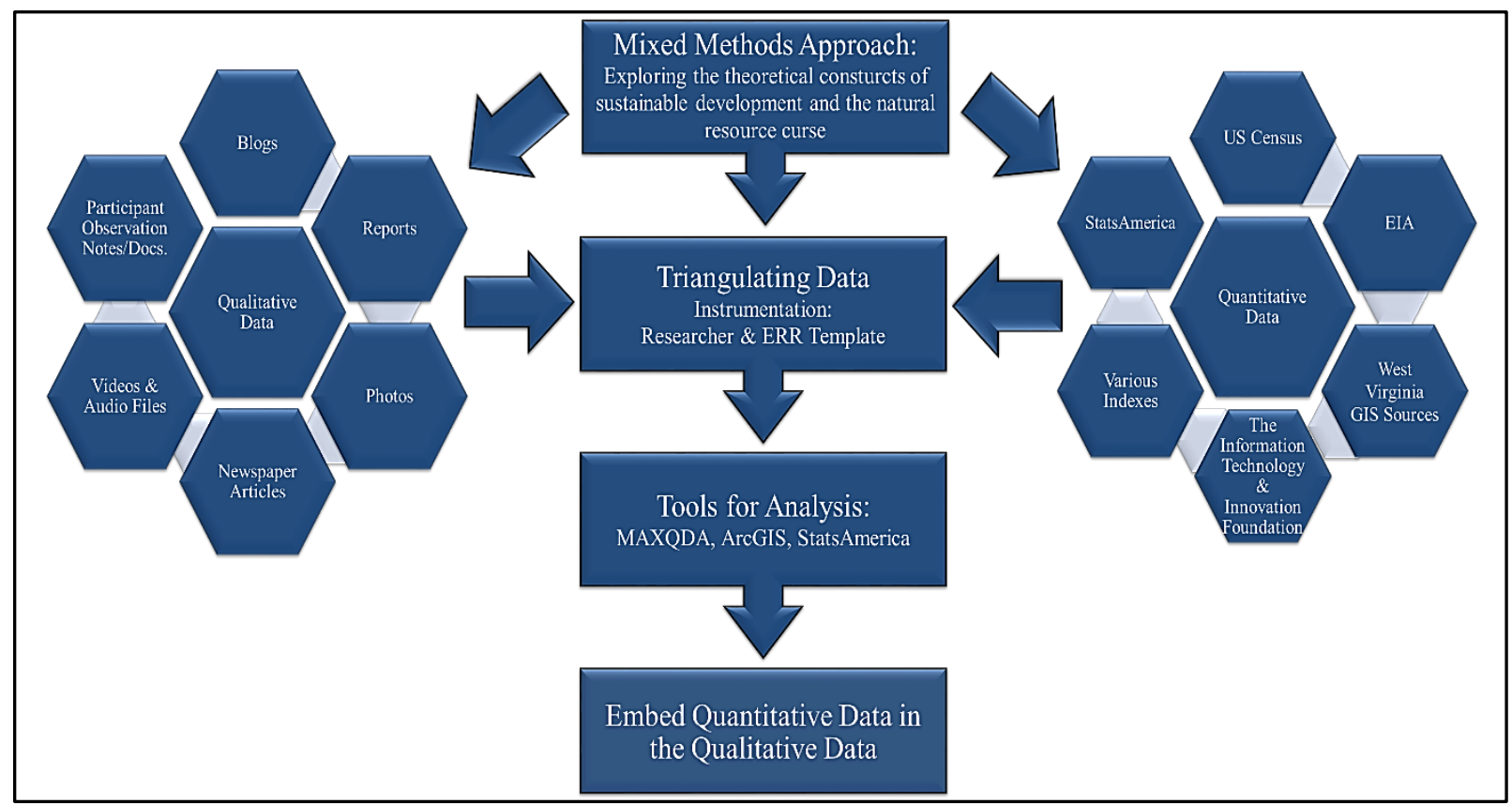

Figure 17. Mixed Methods Approach Process for the Case of Moundsville.

Triangulating data and instrumentation. In referencing Figure 17, a triangulation technique is used for gathering and analyzing data sources. Jick (1979) defines triangulation as a means for seeking convergence across qualitative and quantitative methods. Essentially, the triangulating technique provides results where one method can help develop or inform another method. In addition, triangulation may be used when two or more methods are employed for observing similar results_-which may add strength for what is being observed versus only using one method. In the case of Moundsville, by converging quantitative data and methods (expressed through general numbers and descriptive statistics) with qualitative data and methods (expressed through language and pictures) enhances the analysis portion of the case study.

It's critical to note, there are two main instruments used in conducting the case of Moundsville: (1) the researcher and (2) the ERR template. The ERR template is particularly important because this informs the three primary methods used throughout the case: (1) participant observation activities with the Community Design Team; (2) conducting an open coding process for observing seven years of city council minutes with the assistance of 
MAXQDA; (3) collecting secondary sourced data from the EIA, US Census and knowledge base tools such as StatsAmerica and ArcGIS. The data collected from these methods are then placed in the Moundsville Knowledge Base for further analysis.

\section{Participant observation activities with the Community Design Team (CDT). Field}

procedures are highly dependent on researcher's observations. The method chosen as a participant observer is led by naturalistic inquiry. "Evaluators attempt to study activities and programs in a natural setting without the manipulation or planning by the evaluator” (Patton, 1987). Patton (1987) states, “To understand fully the complexities of many program situations, direct participation in and observation of the program may be the best method” (p. 12). As a participant observer, "the most distinctive opportunity is related to one's ability to gain access to events or groups that are otherwise inaccessible to scientific investigation. The researcher has the ability to perceive reality from the viewpoint of someone inside the case study rather than external to it” (Patton, 1987).

The case of Moundsville is a collaborative effort with the West Virginia University Community Design Team (CDT). The CDT of West Virginia University Davis College started in 1997 and has worked with over forty-five communities in West Virginia. The CDT's goal is to assist communities in designing and planning a vision for the future using a "communitycentered design” (CDT, 2013). This is primarily conducted by bringing a community together via implementation of a proposed project, design, and or potential funding proposal. Ultimately, the hopes are to increase citizen participation to foster a vibrant local culture led by community leaders.

Recognizing this opportunity and acting as a participant observer allows a glimpse into the Moundsville citizens’ lives, thus fostering a sense of place throughout the research process. 
In September of 2012, a pre-visit consisting of CDT members and graduate students from the Department of Public Administration arrived and began to conduct research. This group focuses on the many different aspects found at the community level, including the economy, transportation, tourism, public services, zoning, green space, etc... The team met with a variety of community officials such as the city manager, chief of police, zoning manager, and several council members. Furthermore, the pre-visit provided a general overview of the community including a tour given by city officials and active community members. A brief view was provided showing the impacts from the natural gas industry on the community such as camp sites, campers, portable toilets, and land disputes.

In October, 2012, a more official visit titled “Unifying Moundsville: Unlocking Our Future,” occurred. This extended trip’s purpose consisted of developing a comprehensive plan for the community with fellow colleagues and the citizens of Moundsville. This experience provided a more holistic perspective of the community due to the additional interaction with citizens from a broad range of demographics including teenagers, city officials, working adults, and retirees. In addition, a family graciously volunteered their home and time providing a more enriched and engaging setting to learn about Moundsville from their family’s perspective. The ultimate objective for this CDT's trip was to assist the citizens of Moundsville for realizing their community’s potential, thus allowing citizens to take an active role in their community’s future. After this experience, final reports were submitted in November, 2012. More recently, this engagement process lead to updating the community’s comprehensive plan in July of 2014—the first update of its kind since 1972.

Open coding seven years of city council minutes using MAXQDA. The ERR template informs the researcher for conducting the open coding process for the Moundsville city council 
minutes with the assistance of the qualitative data software program MAXQDA. MAXQDA supports the researcher by exploring the city council minutes which reveals emerging themes. This process begins by (1) collecting text, pdfs, and/or images; (2) organizing the data into document groups - by year in this case; and finally, (3) using an open coding system, the researcher inductively deciphers the data exploring patterns and links between the codes and the data itself.

Data collecting from secondary sources. In collecting data from secondary sources, the ERR template informs the relevant data sources for exploring sustainability through the inclusive wealth forms of human, physical, and natural capital. Much of the data can be retrieved from the U.S. Census, West Virginia Geologic and Economic Survey (WVGES), the Energy Information Administration (EIA) and from knowledge base tools such as StatsAmerica and the software spatial analysis and mapping program ArcGIS.

Tools for analyzing the Moundsville knowledge base. After completing these previous data collecting methods, the data is organized in the Moundsville Knowledge Base. This serves three main functions: (1) improves the case study’s reliability by serving as the case study protocol (Yin, 2003); (2) provides guidance for exploring and analyzing the constructs of a community located in an ERR; and most importantly (3) links the data from the ERR template to the community's sustainable development patterns via inclusive wealth forms which may assist future decision makers for avoiding boom and bust development patterns.

The 'Moundsville Knowledge Base’ consists of categories, sub-categories, and data items for purposes in refining the constructs that play a role in the theory (Figure 18). In this knowledge base, there are three main categories explored; (1) General Profile, (2) Stakeholders, and (3) Community Wealth. 
In referencing the mixed methods approach process, there are three primary tools for analyzing the Moundsville Knowledge Base. (1) ArcGIS- the data sets (shape files) alone from such sources as the WVGES provide a wealth of information including quantitative data on permitted wells, completed wells, cancelled wells, company name, property owner, production etc. This data can then be layers on state and or county maps for observing any spatial patterns. (2)MAXQDA- There are several options MAXQDA has for analyzing qualitative data including ‘code matrix browser', ‘code relations browser’ and 'document portraits’. Other tools assisting the researcher are the 'MaxDictio’ and the‘Mixed Methods’ functions. These assist in quantitative content analysis including word frequencies, variable analysis, crosstabs, and quote matrix. (3) Finally, there are several free knowledge base tools that retrieve secondary sourced data, e.g., U.S. Census, U.S. Bureau of Labor Statistics, that provide options for exploring data differently. One such site for locating such tools is StatsAmerica.org where a suite of tools and information may be employed for analyzing data regionally, including the Innovation Index, Counties in Profile, and Industry Clusters. 


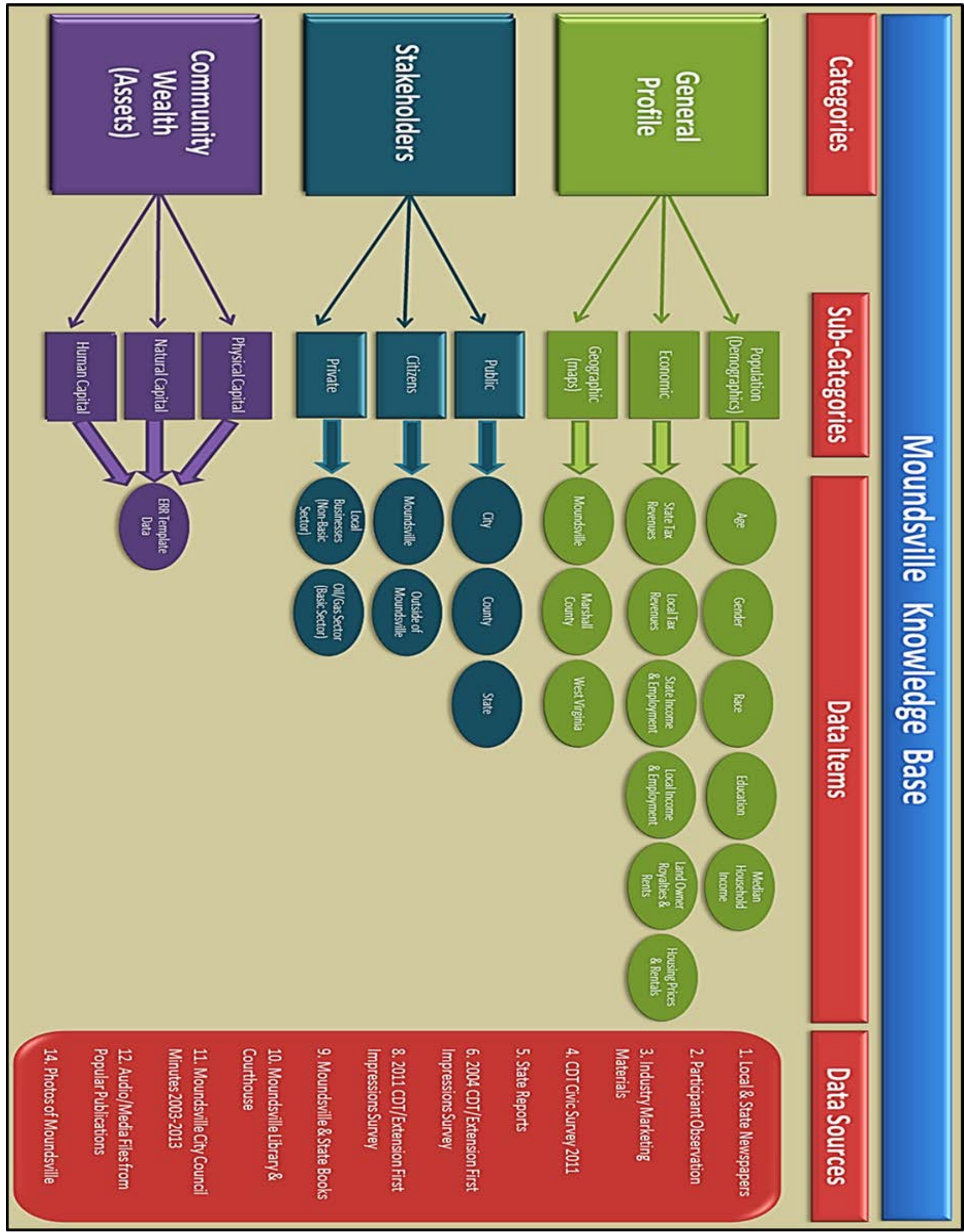

Figure 18. Moundsville Knowledge Base 
Embed quantitative data into qualitative data. Finally, the last part of the procedure in the mixed methods approach is embedding the quantitative data into the qualitative data. Much of the data collected throughout this case is of qualitative nature. By combining both quantitative and qualitative results improves the strength of observation (Creswell, 2003). Throughout this process, there have been multiple methods employed which have informed other methods and may reveal similar results (previously identified as triangulation). This is the end product of the procedure where the qualitative results are enhanced by the quantitative results as presented in Ch. IV.

\section{Reliability and Credibility}

Lincoln and Guba (1985) suggest the trustworthiness of a qualitative study is important to evaluating its worth. This involves establishing (1) credibility, (2) transferability, (3) dependability, and (4) confirmability. The following provides techniques that were utilized in conducting this case study.

"Validity, in qualitative methods hinges to a great extent on the skill, competence, and rigor of the evaluator because the observer is the instrument” (Patton, 1987, p. 12). "The most common strategy to control for bias in qualitative studies is reflexivity” (Ary, Jacobs, Sorensen, 2010, p. 501). A researcher should be unbiased by preconceived notions, including those derived from theory. Thus, the researcher should be sensitive and responsive. Recognizing and actively seeking researcher bias throughout the data gathering process will support efforts in maintaining reliability and improves the construct validity of the case. Credibility is improved by having multiple sources of empirical evidence and using a mixed method approach to the case study design (triangulation). One such method utilized (participant observation) assists in establishing 
credibility of this case study. The observations from this experience were recorded through notes and journal while visiting Moundsville.

An effort for improving the reliability and credibility during the data collection phase of this case study involves the creation of a case study protocol as recommended by Yin (2003) and the creation of the 'Moundsville Knowledge Base'. The protocol should contain the following:

1. An overview of the case study project including background information about the project, the substantive issues being investigated, and the relevant readings about the issues;

2. Field procedures;

3. Case study questions;

4. A guide for the case study report (pp. 84-85).

This allows a researcher to see and thoroughly process the many stages in conducting a case study and creates a more systematic case.

The use of the qualitative data software MAXQDA supports the researcher in addressing the internal validity specifically during the data analysis portion of the case by allowing one to inductively explore the data during open coding 'grounded theory’ (Glaser \& Strauss, 1967)— developing theory from the data itself.

The transferability of this case study is described in rich detail for potentially replicating this framework for future case studies involving similar communities within energy rich regions. Furthermore, for improving the dependability of the instrument, the ERR template was previously tested in a classroom setting and expert feedback was provided. 


\section{Chapter IV}

\section{Analysis and Findings}

The main purpose of this case study is to explore sustainability through the inclusive wealth forms of natural, physical, and human capital and to determine whether natural capital is being adequately and sufficiently converted to physical and human capital so that 'wealth'which is total of all three assets, does not decline over time. The previous literature review suggests, if the 'wealth' or total capital stock is not declining, then this would seem to suggest the community of Moundsville is on a more sustainable path.

The following findings begin with an overview of the community wealth and then moves into the capital forms that make up this wealth. Next, a qualitative review of these capital forms enriched with quantitative support from secondary sources and knowledge base tools is provided. Furthermore, throughout this case study findings are the open coding results from the MAXQDA which reveals additional dimensions to these capital forms including a community's efficacy and how this additional dimension ultimately may hinder a community's ability to avoid a boom and bust development pattern. Finally, a brief discussion is needed for linking the previous literature to the findings observed here.

\section{Community Wealth (Assets)}

Located along the Ohio River in West Virginia’s Northern Panhandle, Moundsville serves as the county seat for Marshall County. Moundsville is named after the largest conical burial mound in the United States, Grave Creek Mound. It was built by the Adena culture approximately 2000 years ago. 


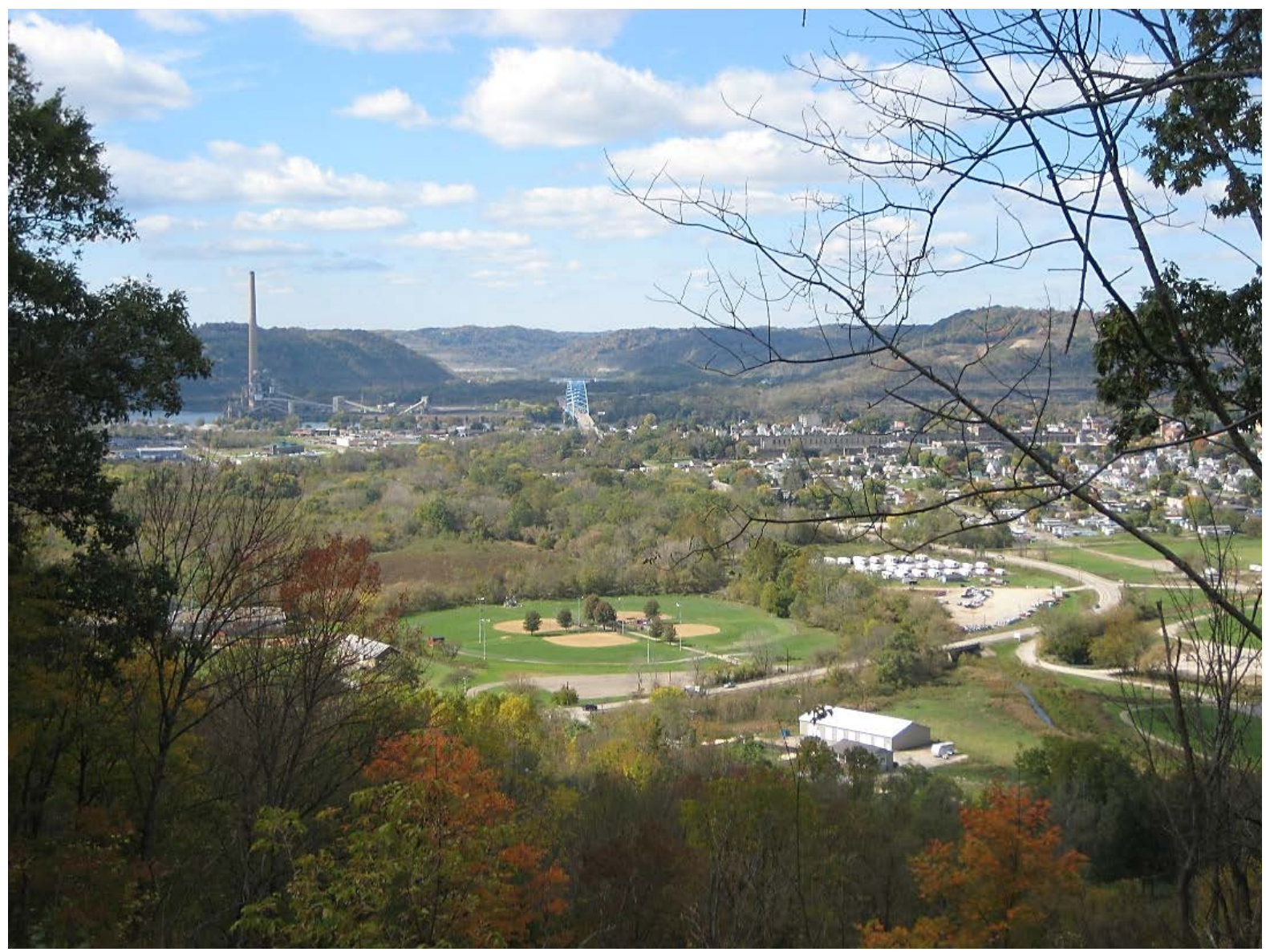

Figure 19. The Community of Moundsville. Kiger, B. (Photographer), 2012.

Visiting the community, one may be surprised by the available wealth of community assets that would be expected from a typical "small rural town” in West Virginia. The community has a great historical significance-not only from an energy perspective, but in industry/manufacturing (Fostoria Glass Factory, United States Stamping Factory, Fokker Aircraft, Louis Marx Toy Factory), home to the West Virginia Penitentiary (Appendix C), and even some notable beautiful interior and exterior architecture, e.g., the Strand Theater (still in use today) (Appendix C). The main industries in Marshall County include health care, mining, local government, manufacturing, and retail. The largest employer is Consolidation Coal Company(CONSOL Energy), but other major employers included Ohio Power Company, Marshall County Board of Education, Reynolds Memorial Hospital Inc., PPG Industries, Wal- 
Mart, and Williams Energy . However, similar to many other smaller communities throughout the Appalachia region-Moundsville is experiencing a development pattern of boom and bust from the 'natural resource curse'. Although, the most recent boom in natural gas is bringing wealth to the community, it is a critical time for implementing sustainable development strategies through informed decision making by community leaders. Reiterating, the overarching inquiry here-is the Moundsville community converting the natural wealth (natural gas) to the reproducible forms of human and physical capital towards a more sustainable and prosperous future?

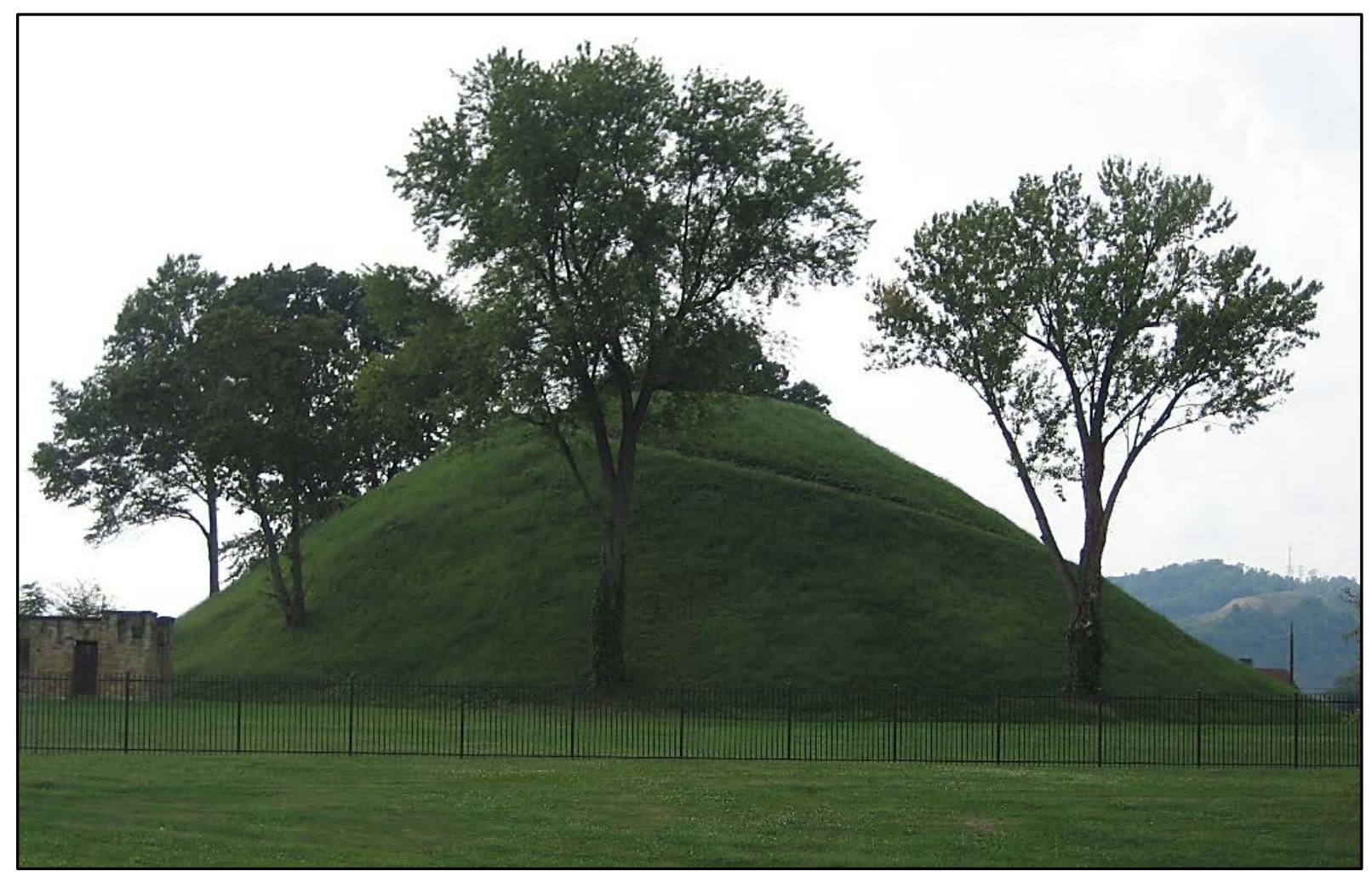

Figure 20. Grave Creek Mound. Kiger, B. (Photographer), 2012.

After inductively coding seven years of city council minutes for Moundsville and then aggregating these codes into the three main forms of wealth, the assets coded most often are revealed. It should be noted, a number of sub-codes that appeared fewer than 10 times were aggregated into the code's parent code for simplifying the coding system. For example, if the 
sub-code 'murder' is coded only 3 times, then the segments coded under 'murder' would be aggregated into the 'murder's' parent code 'crime and death'. This task of coding is made more systematic and consistent with the assistance of the qualitative data analysis software MAXQDA. The complete list of 112 codes and sub-codes can be found in Appendix C including the percent frequency and number of documents for each particular parent code and sub-code.

Table 3

MAXQDA Aggregate Codes for Moundsville City Council Minutes, 2006-2012

\begin{tabular}{|l|c|c|}
\hline \multicolumn{1}{|c|}{ Aggregate Code } & Activated Coded Segments & Activated Coded Segments \% \\
\hline Positive & 493 & 4.6 \\
\hline Negative & 874 & 8.1 \\
\hline Human Capital & 5914 & 54.6 \\
\hline Physical Capital & 3214 & 29.7 \\
\hline Natural Capital & 346 & 3.2 \\
\hline Total & 10841 & 100 \\
\hline
\end{tabular}

The open coding process is informed by key definitions of natural, physical, and human capital derived from the ERR template. An assumption is made that greater frequency of discussions or key words positively correlates with importance and/or are a higher priority. The results in Table 3 reveal discussions involving natural capital comprised approximately 3\% of the total coded segments. Considering the increase in natural gas activity throughout the county, the result is counterintuitive-one would expect a greater frequency for natural capital. In addition, there are times where a particular capital may have poor efficacy, or in other words, not all human capital is necessarily 'positive'. This became more evident while coding, hence a dimension of efficacy was added to these capital forms. For example, for each code there may be a sense of emotion attached such as 'negative' which is apparent in the following example: 
* Councilperson Remke asked what can be done about the buildings with boarded windows or windows falling out? Windows above Ken Blake Photography are broken and falling out; windows at 301 Jefferson Avenue, above Dr. Gresak's Office are falling out and the large window at Cottage Corner, 273 Jefferson Avenue, has been boarded up for a very long time. Councilperson Remke would like to revise the city code to enforce building owners to replace windows with glass. Building Inspector Schneider advised the owners of the building the windows must be replaced.

(CityCouncilMinutes201212-07-2012: 415-526)

This segment is coded as the parent codes of both human and physical capital, with subcodes of negative, small business, policy, and dilapidated structures. In the above example, clearly there is an issue with a dilapidated structure and the council would like the structure to be fixed after years of neglect. In this particular example, it is assumed a dilapidated structure has a negative efficacy dimension of human capital for the community.

The following results are broken into three sections beginning with natural capital and then moving into physical capital and finally human capital. The reader can expect a pie chart at the beginning of each section illustrating the percent frequency of sub-codes for each inclusive wealth form. 


\section{Natural Capital}

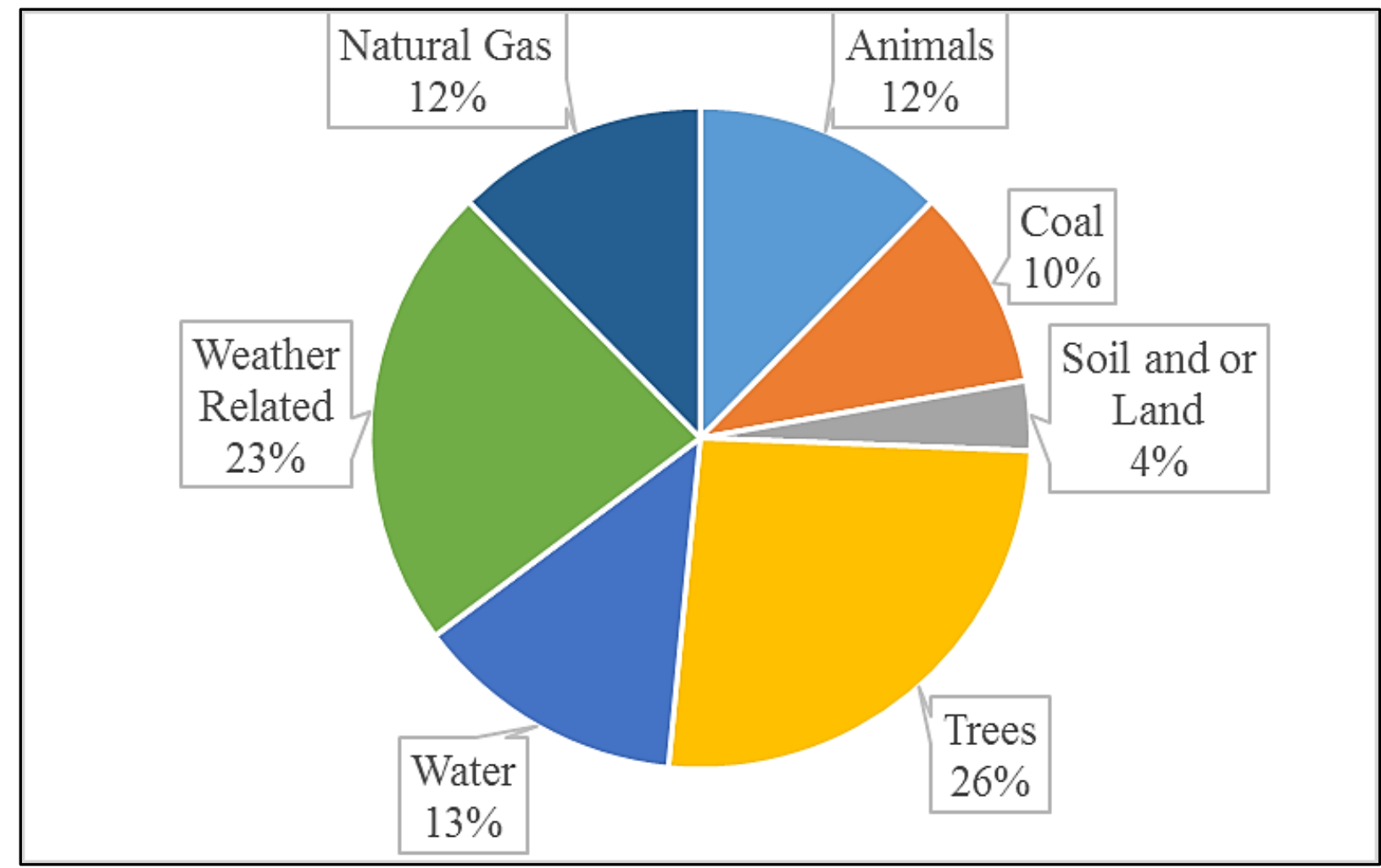

Figure 21. MAXQDA Results Total Percent Proportion of Natural Capital with Primary Subcodes.

The process for coding natural capital is informed via the potential indicators from the ERR Template. As previous literature reveals, natural capital most commonly refers to anything that is mined from the ground, but may also include water, trees, weather, and the eco-services provided from these natural elements. Figure 21 shows 'Trees' and 'Weather Related' were coded most often for natural capital. This is primarily due to weather effects on many of the operations of city including cleaning roads and sidewalks, but also, flooding has been an issue for the community and most often fallen trees and debris are having to be cleaned-up and/or maintained. In addition, it may be important to observe by aggregating the sub-codes of natural gas and coal would reveal discussions revolving around coal and natural gas are quite common. 
In observing the natural capital in the Moundsville Community Knowledge-Base, the first documented case of permitting in the Marshall County specific to the Marcellus Shale was used as a baseline. June, 2006 was observed as the first gas well with a drilling completion date of November, 2006. Generally, this documents the pre-boom stage and current boom. Figure 22 references the permitting which lends support for distinguishing between these two periodspre-boom and current boom. The largest percentage jump for permitting is 525\% between years 2010 and 2011. There is a decrease of 38\% between the years of 2012 and 2013, but this is more than likely due to an incomplete data set. The last recorded permitted well for this data set ended in June of 2013, thus only allowing half a year of permitting data.

Understanding the past timeline of permitting events informs the most relevant years for analyzing the Moundsville city council minutes. This shortens the time period under most critical observation of 2006-2012 in which one would expect an increase in discussion activity relating to natural gas among stakeholders specifically between public representatives and citizens of Moundsville. Furthermore, in referencing Figure 22, one would expect an even greater frequency of discussions as it relates to natural gas between the years 2010 and 2011. 


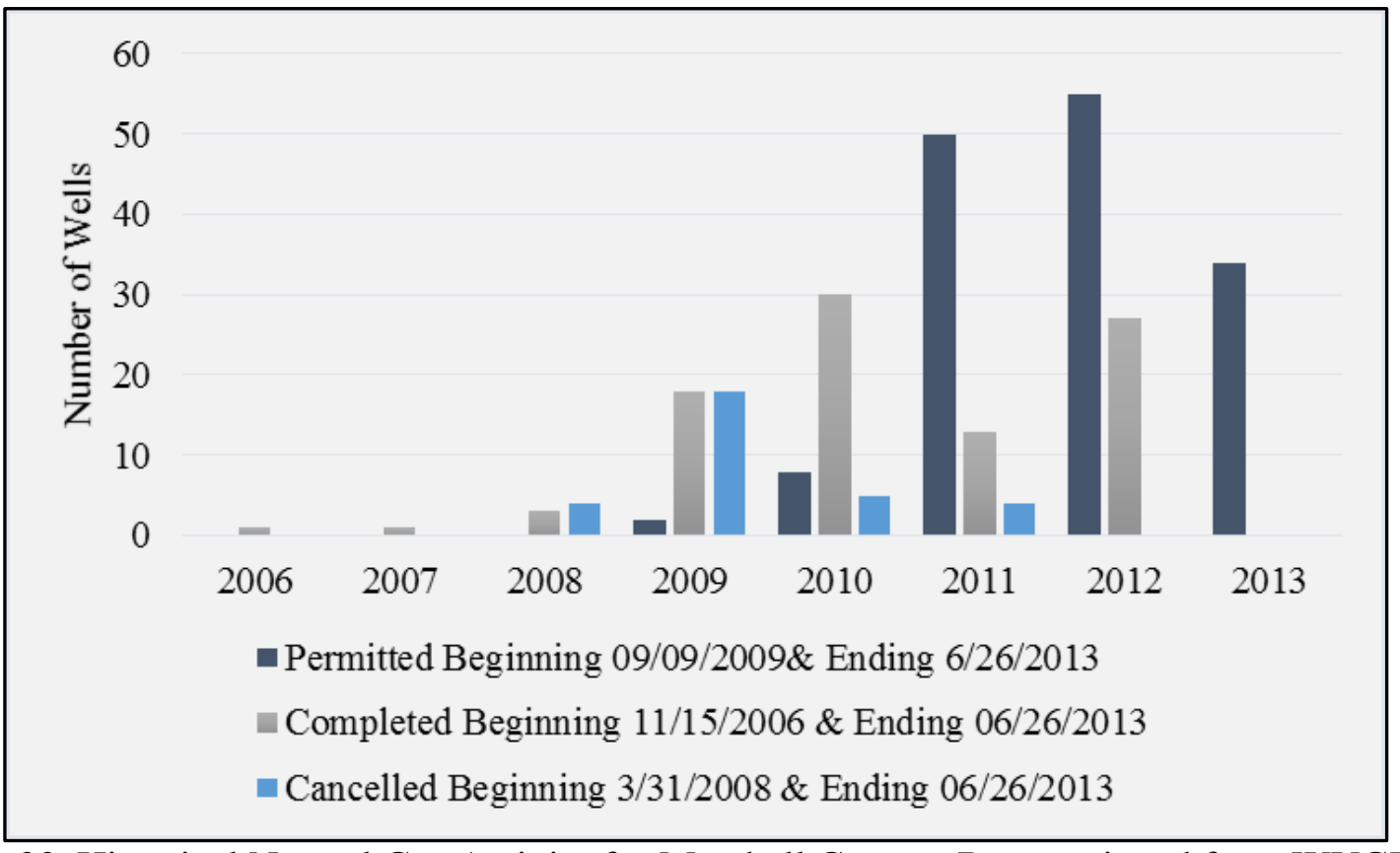

Figure 22. Historical Natural Gas Activity for Marshall County. Data retrieved from WVGES.

As of 2013, Marshall County total gas production was 68,468,821 Mcf and in 2006 it was only 376,895 Mcf (Figure 23). This places Marshall County as the $4^{\text {th }}$ most producing county in West Virginia behind Harrison, Wetzel, and Doddridge counties in that order.

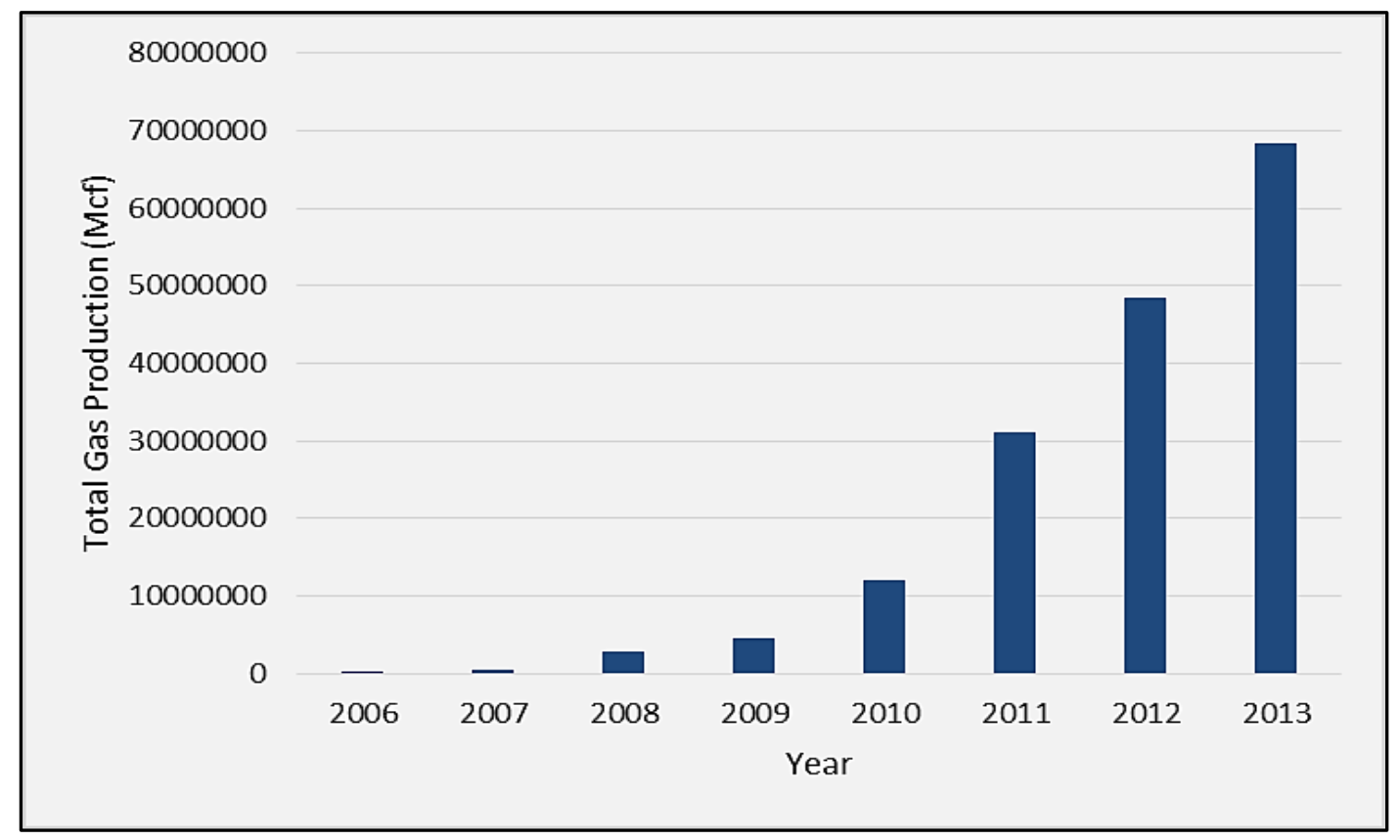

Figure 23. Marshall County Well Production 2006-2013. Data retrieved from WVGES. 
Utilizing ArcGIS 10.1 and data sets retrieved from the WVGES, the following maps illustrate spatially the natural gas activity by county in terms of permitted and completed wells beginning at the state level and then narrowing our spatial analysis to Marshall County.

In exploring these maps, a few visual patterns are apparent including a high concentration of permitting in the north central counties (Figure 24) and a high concentration of completed wells in north central counties, and southwestern counties (Figure 25). This is logical considering most drilling in the state began in the southwest central region which is traditionally seen as 'coal country'. Natural gas exploration first began in the southwest portion of the state due to shallower depths resulting in less expense for retrieving the gas. However, as the price of natural gas decreases, permitting in the north central part of the state has increased due to the prevalence of wet gas. 


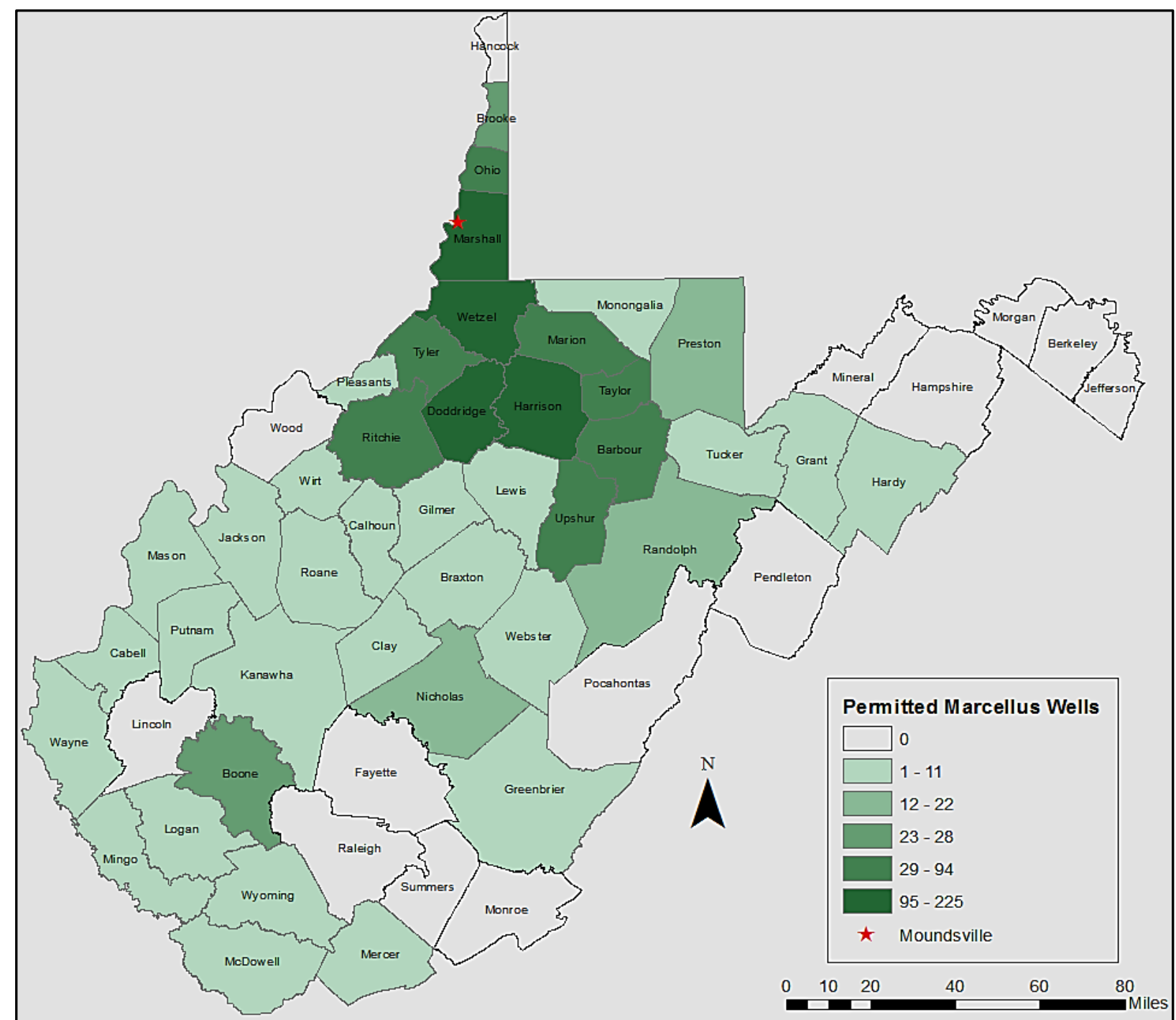

Figure 24. Permitted Marcellus Wells as of June 2013. Data retrieved from http://www.wvges.wvnet.edu. 


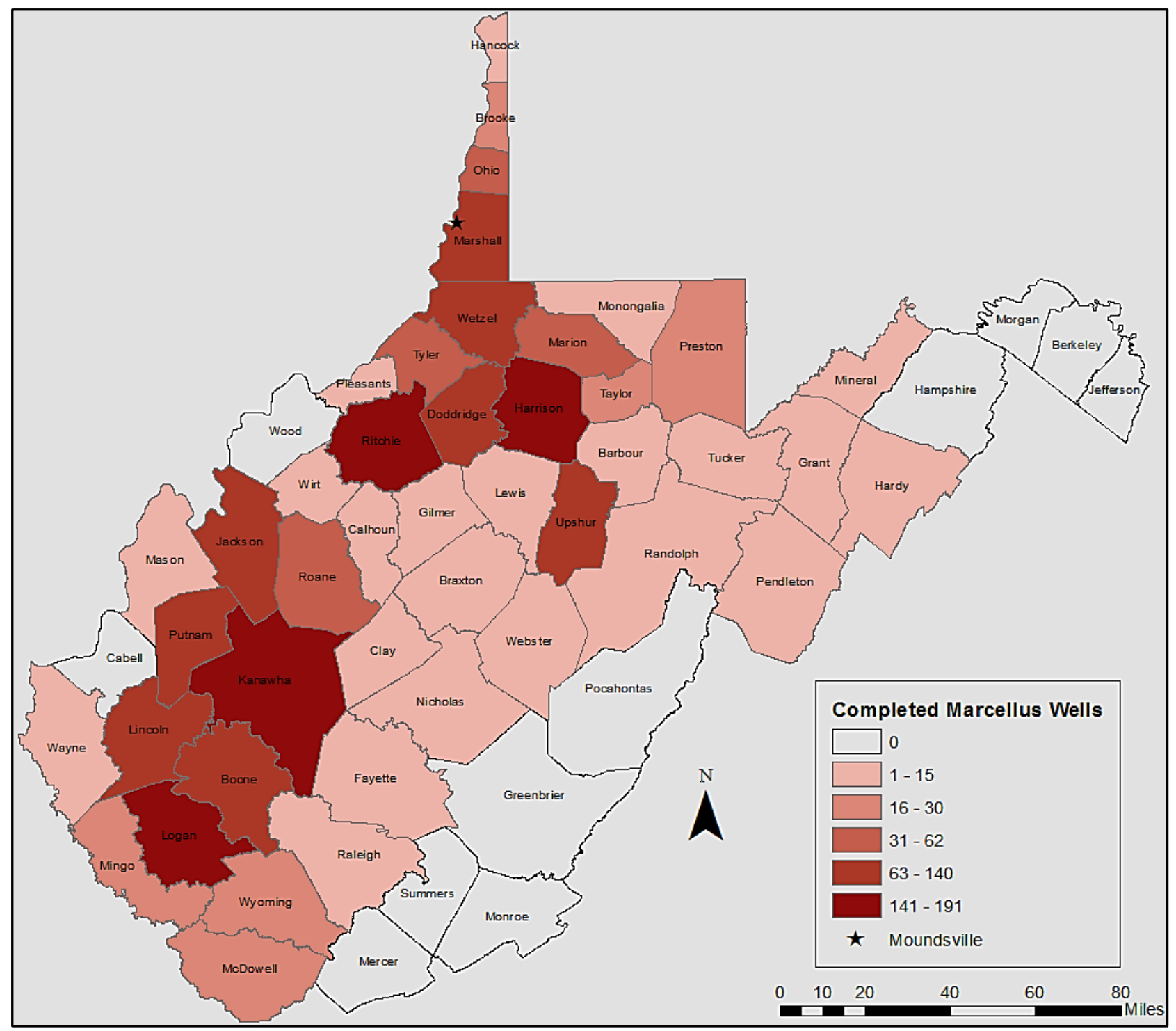

Figure 25. Completed Marcellus Wells as of June 2013. Data retrieved from http://www.wvges.wvnet.edu.

Aggregating the two previous maps and comparing spatially against the backdrop of the median household income at the county level lends support to what has been commonly seen in previous research analyzing the natural resource curse (Figure 26). Although the state may be rich in natural capital, the human capital is poor in terms of economic wealth and quality of life. In fact, one indicator of economic wealth and quality of life is the median household income which shows Moundsville with 37\% below the nation's median household income and the state of West Virginia ranked $49^{\text {th }}$ out of 51 (including D.C.). 


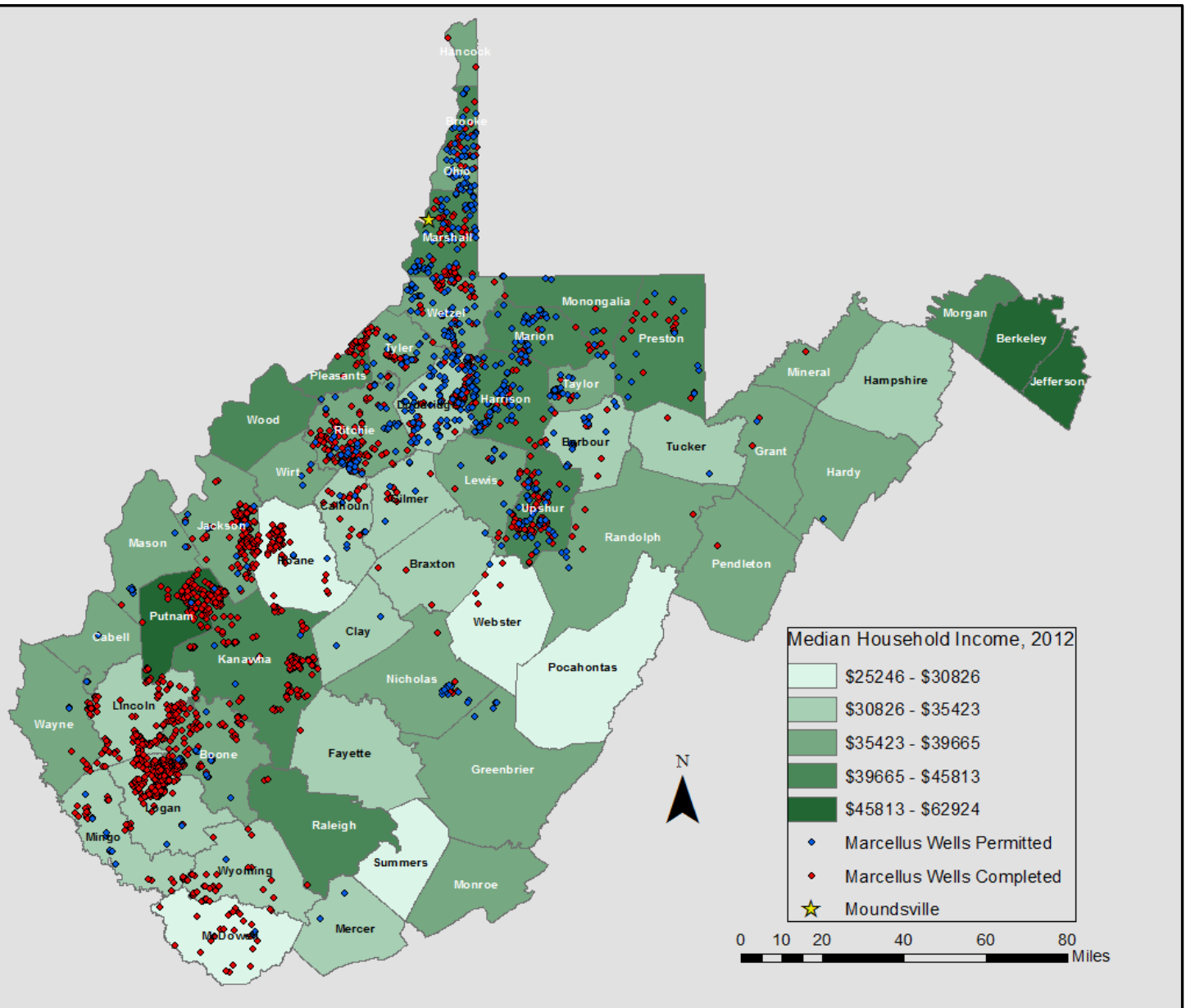

Figure 26. Median Household Income (as of 2012) vs. Natural Gas Activity (as of June, 2013). Data retrieved from www.wvgs.wvnet.edu/.

Table 4

Median Household Income Comparison

\begin{tabular}{|c|c|c|c|c|c|}
\hline Data Item & Moundsville & Marshall County & West Virginia & U.S. & $\begin{array}{c}\text { Rank in } \\
\text { U.S. }\end{array}$ \\
\hline Median Household Income & $\$ 33,694$ & $\$ 40,288$ & $\$ 40,400$ & $\$ 53,046$ & 49 \\
\hline
\end{tabular}

Data retrieved from U.S. Census Bureau, 2008-2012 American Community Survey.

Marshall County is located in the north central part of West Virginia with an approximate

total land area including open water of 311 square miles (1.3\%) of the 24,229 total square miles in the state. There are no major cities found within Marshall County, although there are several small towns including Moundsville, Benwood, McMechen, Glen Dale, and Cameron. 
In exploring the impacts resulting from the natural gas industry, it’s important to take stock of the natural features and the potential concerns that may arise relating to the boom in natural gas. Natural features in Marshall County include one major river, the Ohio River, and 23 watersheds that contain a combination of 1,387 streams, creeks and rivers (WVGES data, retrieved via ArcGIS).

Table 5

Land Cover Distribution of Marshall County

\begin{tabular}{|l|c|c|}
\hline \multicolumn{2}{|l|}{ Environment } \\
\hline \multicolumn{1}{|l|}{ Land Cover (square miles) } & Region Value & $\%$ Total Area \\
\hline Total Land Area & 311.95 & $100 \%$ \\
\hline Forest \& Woodland & 237.9 & $76.28 \%$ \\
\hline Agricultural Vegetation & 38.74 & $12.42 \%$ \\
\hline Developed \& Other Human Use & 26.96 & $8.64 \%$ \\
\hline Open Water & 8.06 & $2.59 \%$ \\
\hline Other & 0.25 & $0.08 \%$ \\
\hline
\end{tabular}

Data retrieved using USGS Land Cover Viewer tool found at http://gis1.usgs.gov/csas/gap/viewer/land_cover/Map.aspx.

Approximately 75\% of Marshall County is deciduous forest and pasture/hay is the next highest land cover type at $12 \%$. The average elevation of Marshall County is $1,137 \mathrm{ft}$., with a low of $594 \mathrm{ft}$. and a high of $1600 \mathrm{ft}$. Figure 27 reveals the interplay between these natural features, communities, and natural gas wells throughout the county. As of June, 2013 there were a total of 273 natural gas wells in terms of permitted and completed. Furthermore, this reveals the nexus between water and the processes involved in extracting natural gas are seemingly unavoidable which adds a potential risk to the human health and the environment alike. In addition, gaining access to these sites is an obstacle due to the hilly country side. Furthermore, this map shows that exploring the interplay of Moundsville and these drilling sites requires observing development patterns of Marshall County too. The permitting and drilling of wells 
remain outside the municipal boundaries of these smaller five communities including

Moundsville, thus limiting the control and potential economic gains.

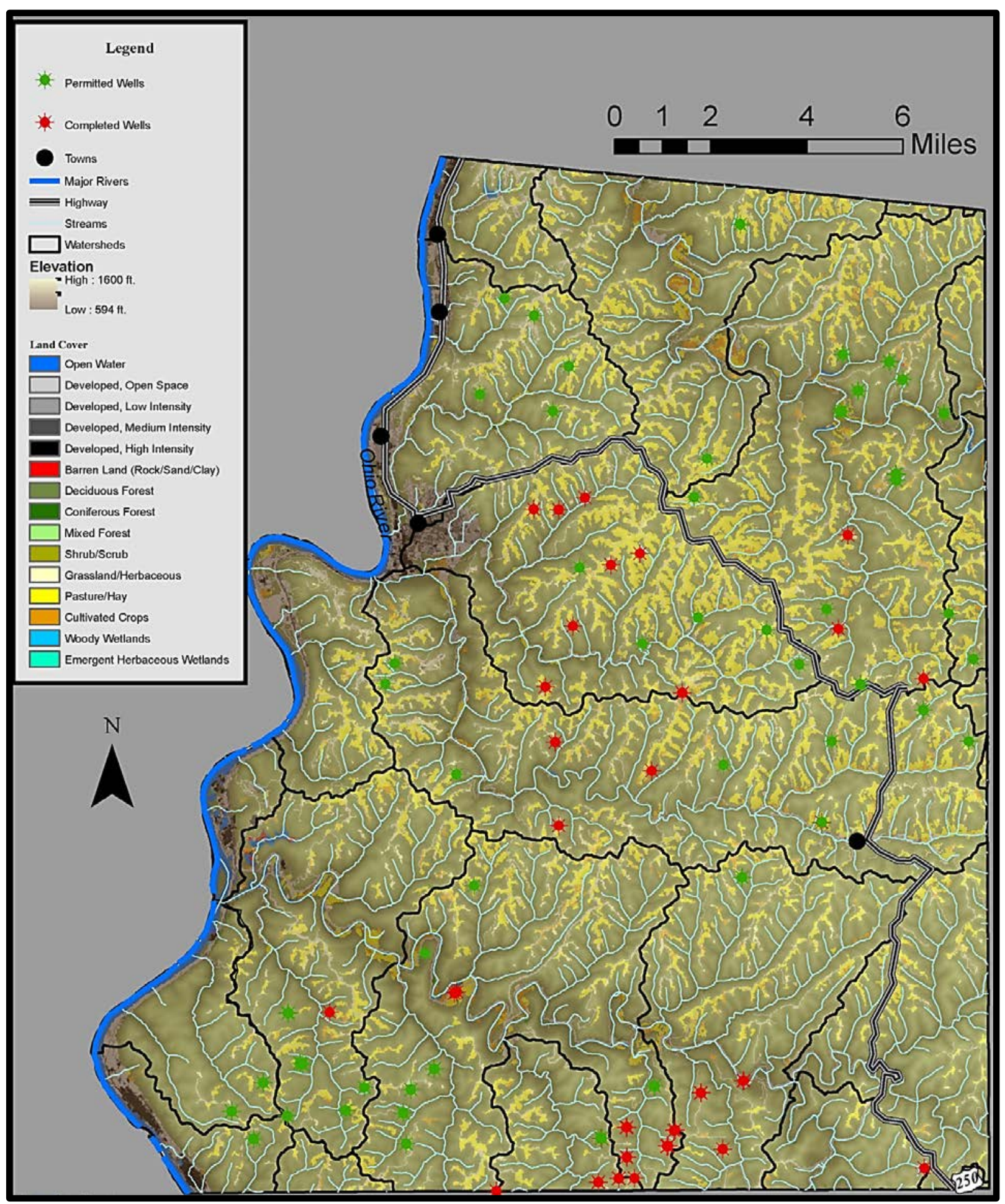

Figure 27. Marshall County Completed and Permitted Wells. Data retrieved from http://www.wvges.wvnet.edu. 


\section{Physical Capital}

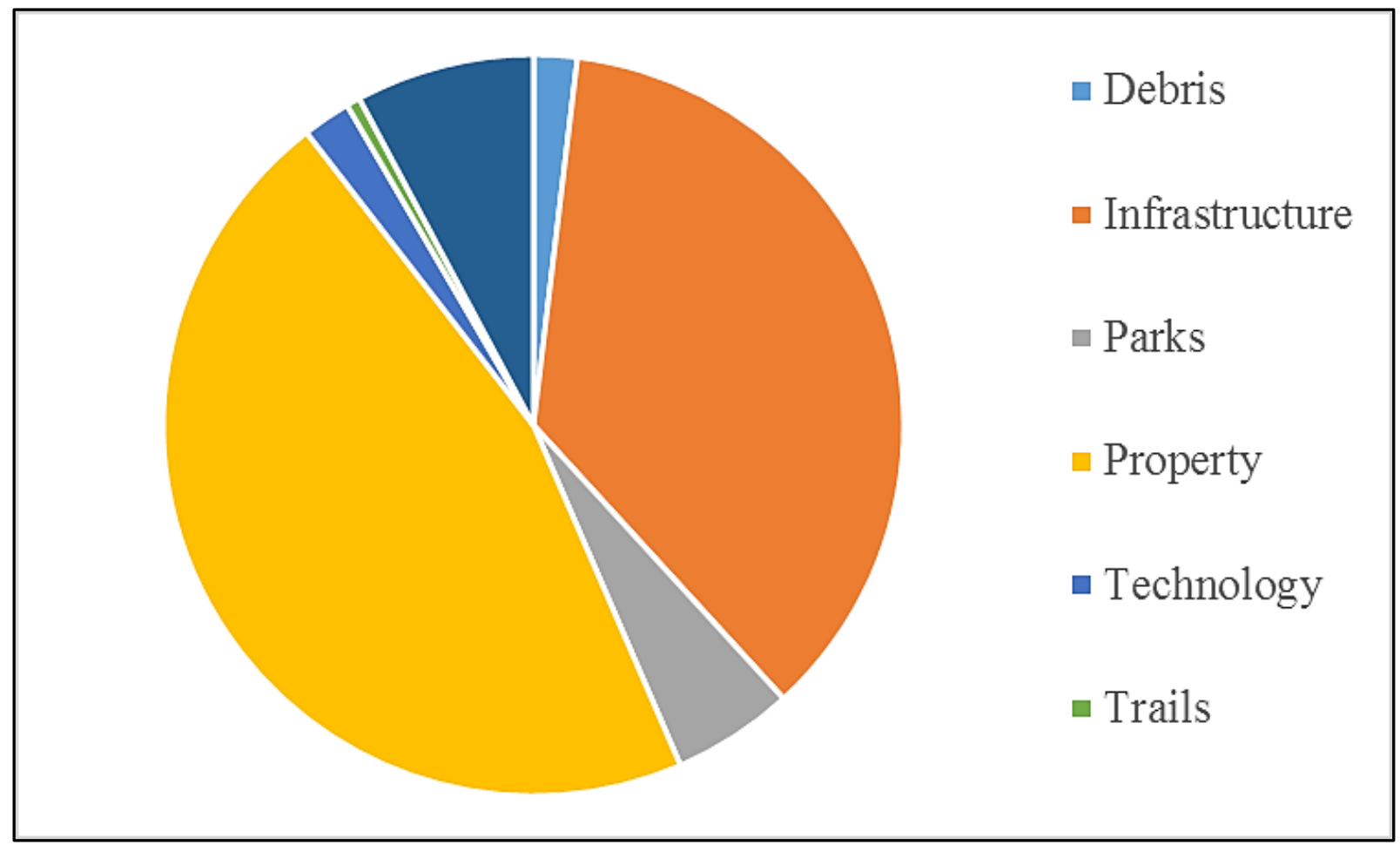

Figure 28. MAXQDA Results Total Percent Proportion of Physical Capital with Primary Subcodes.

The process for coding physical capital is informed via the potential indicators from the ERR Template. As revealed in previous literature, physical capital most commonly refers to anything that is man-made such as roads, buildings, housing, vehicles and equipment and parks. One might suggest parks should be coded as natural capital, however for distinguishing the difference, a decision is made based on the fact parks are man-made and require continued maintenance. Figure 28 shows 'Infrastructure' and 'Property' were coded most often for physical capital. This is primarily due to constant complaints of poor road conditions (pot holes, resurfacing needs etc...), dilapidated homes/buildings and property nuisances. 

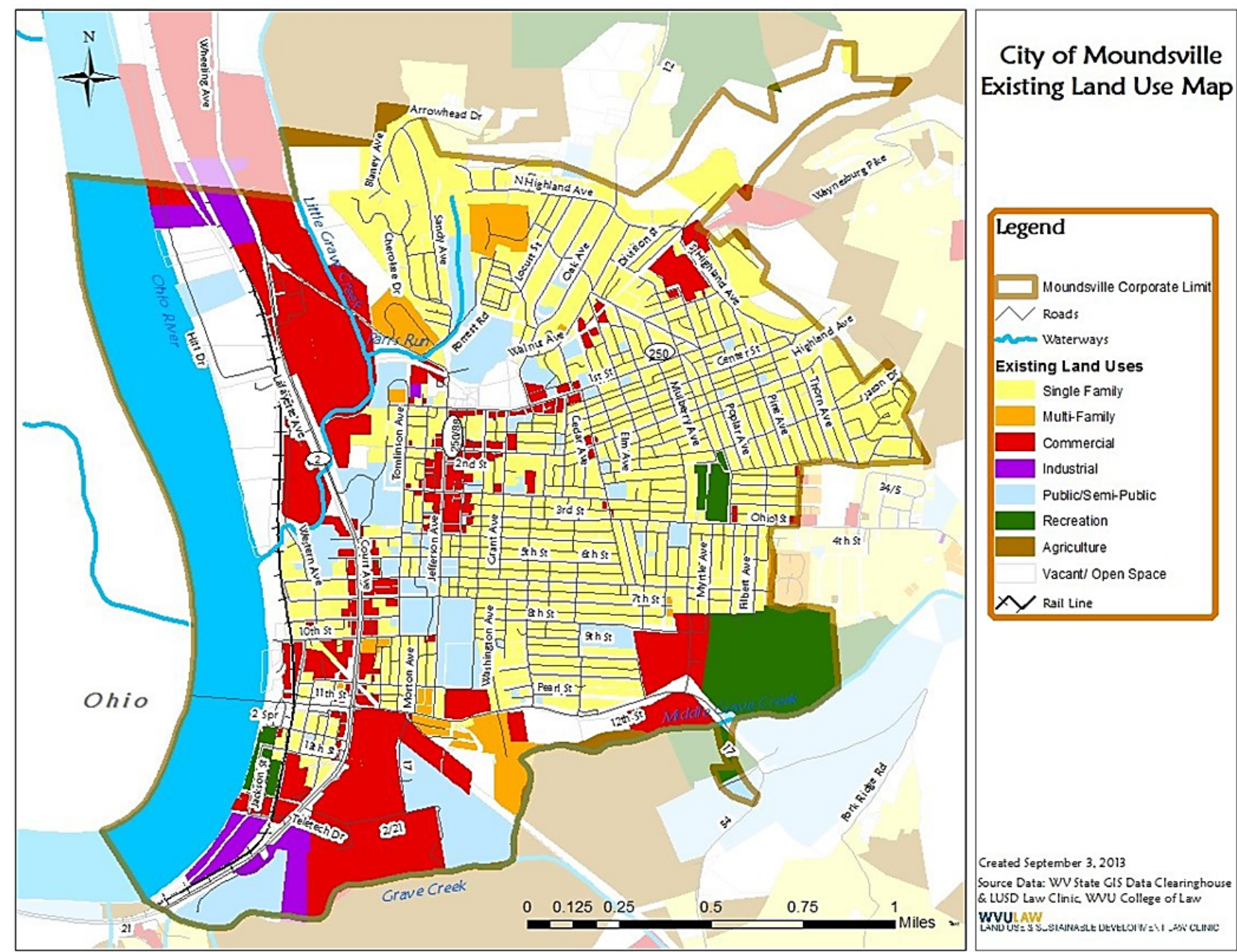

Figure 29. City of Moundsville Existing Land Use Map. Retrieved from City of Moundsville Comprehensive Plan, Adopted July 2014.

The 2014 City of Moundsville Comprehensive Plan provides a detailed overview of the current physical capital in the city and county. The city has approximately eighty-eight acres of parks within its boundaries and include such amenities as baseball and soccer fields, an indoor community pool, and a walking/bike rail trail. There are currently eight elementary schools, two middle schools, and two high schools located throughout Marshall County.

The city operates its own water facility which includes the potable water supply, processing of wastewater and storm water. The plan notes there were upgrades made to the facility beginning in 2006 and have continued for several years. "However, capacity remains an issue, particularly with the influx of oil and gas workers. These workers, often temporary 
residents living in RV campgrounds, are required to hook up to the city water lines” (Moundsville Comprehensive Plan, 2014, p. 2-9).

A large part of the budget is spent on transportation and roads. For FY 2011-2012, the amount spent on street and transportation was approximately \$1.1 million which was 19\% of the total Moundsville budget. There are two small airports in the county, but no active rail lines. In addition, there are two primary roads that intersect with the city which includes State Route 2 which traverses the Moundsville Bridge (Figure 30) into Ohio, and U.S. Route 250.

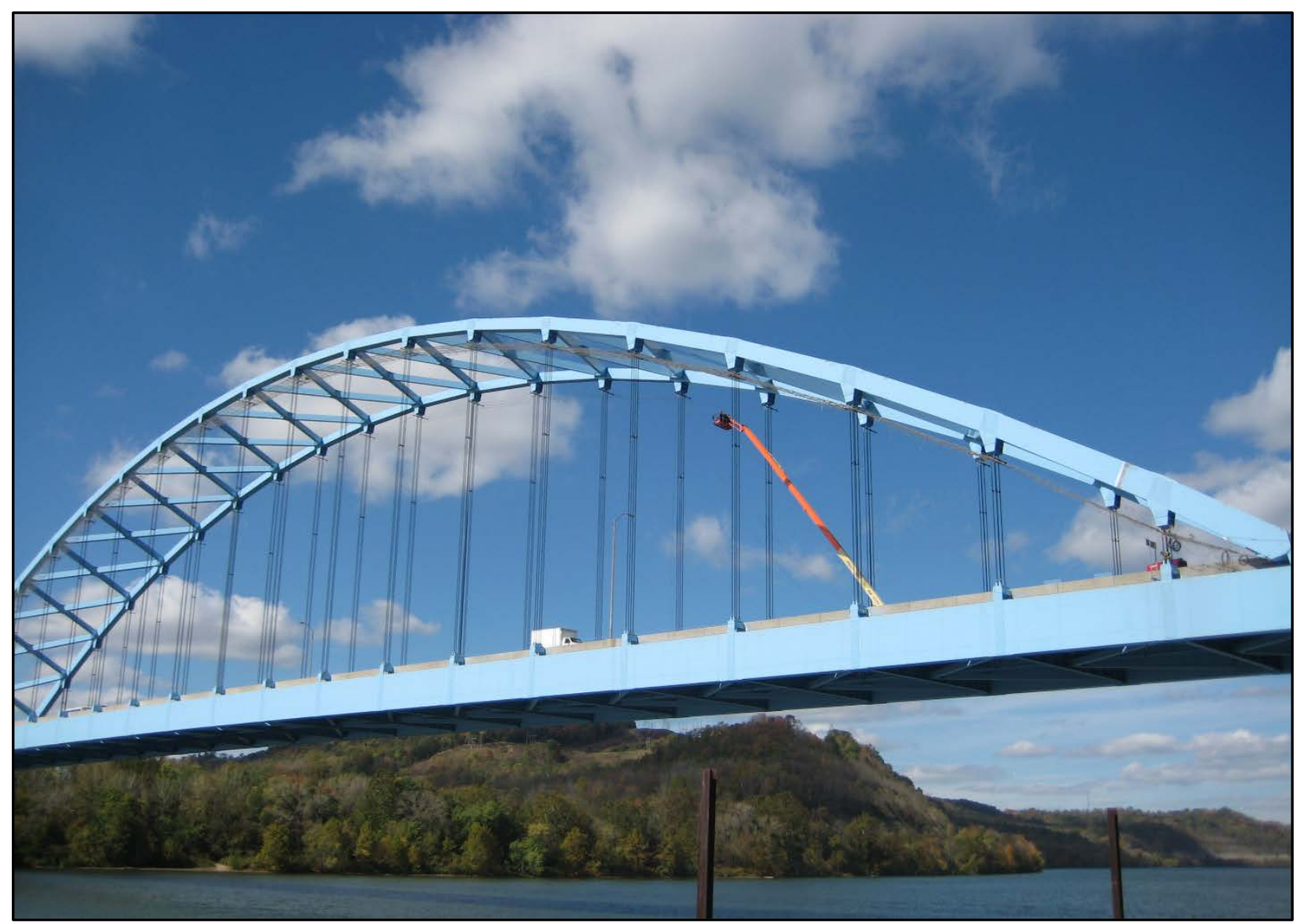

Figure 30. Moundsville Bridge Leading into Ohio. Kiger, B. (Photographer), 2012.

When visiting Moundsville as a participant observer, a few images presented themselves while exploring the community (Figure 31). While coding the city council minutes, a pattern 
reveals substantial issues with the built environment including vacant business properties, dilapidated housing, and property nuisances.

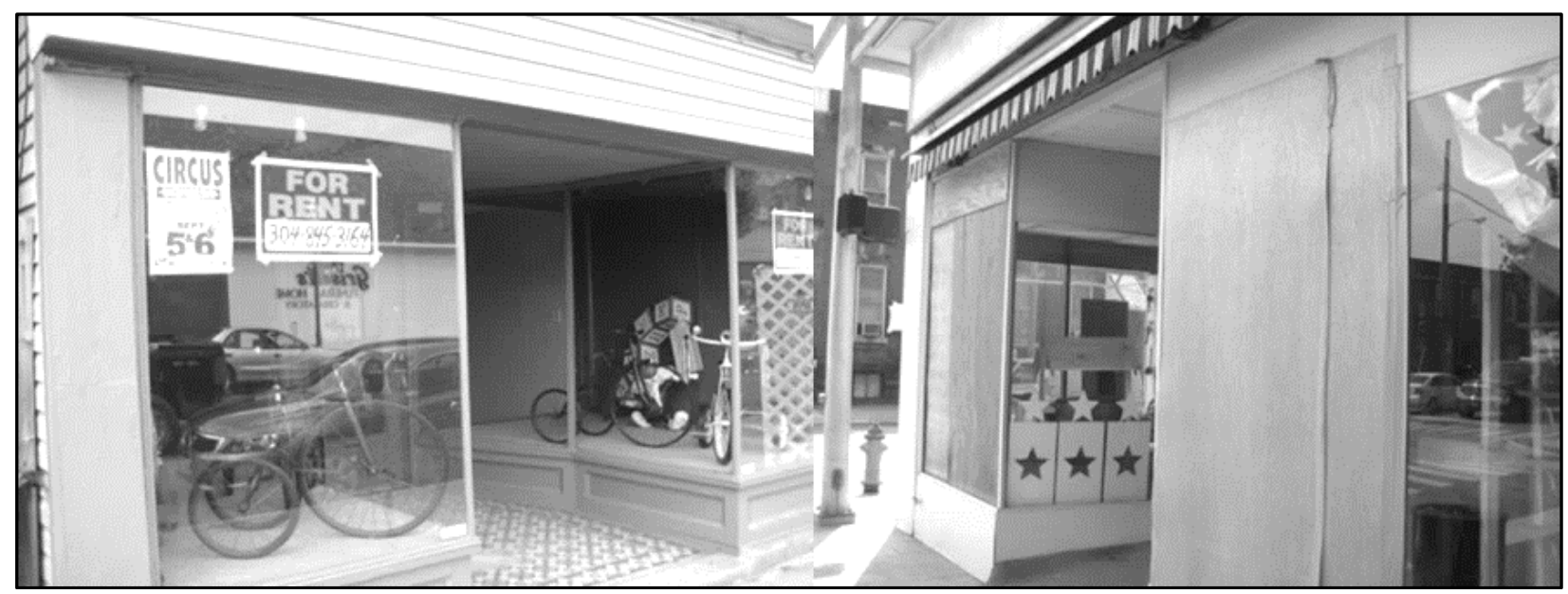

Figure 31. Empty Store Fronts, Main Street, Moundsville. Kiger, B. (Photographer), 2012.

Figure 28 revealed the total physical capital with the main sub-codes. The frequency of the sub-code 'property' occurs most often at $46 \%$. If we dig deeper into this code, it reveals an additional layer of sub-codes including those of dilapidated, vacant, and nuisance properties.

A crosstabs function using MAXQDA is applied comparing the variable of 'years' to these sub-codes listed under the parent code 'physical capital'. The independent variable 'year' is used with the assumption that the permitting of wells and or drilling of wells are related to the variable 'year', thus providing a link across time to the physical capital in Moundsville during the boom in natural gas. The results are listed in Table 6. Highlighted in yellow, we observe a pattern of coding for the sub-codes of property nuisance, housing, and dilapidated aging or vacant structures. These sub-codes continue to increase until 2010 and then begin decreasing in 2011. This trend would most likely continue to increase and or even peak through 2011; however, due to incomplete data, only half of the year's city council minutes are observable as noted with an asterisk in the number of documents for 2011. 
Table 6

Total Physical Capital with Sub-Codes Percentage vs. the Independent Variable Year

\begin{tabular}{|c|c|c|c|c|c|c|c|c|}
\hline Code System & 2006 & 2007 & 2008 & 2009 & 2010 & 2011 & 2012 & SUM \\
\hline Physical Capital & 33.33 & 17.46 & 7.94 & 12.70 & 11.11 & 7.41 & 10.05 & 100.00 \\
\hline Physical Capital Infrastructure & 4.76 & 14.29 & 9.52 & 9.52 & 42.86 & 7.14 & 11.90 & 100.00 \\
\hline $\begin{array}{l}\text { Physical Capital } \backslash \text { InfrastructurelElectric } \\
\text { Lines }\end{array}$ & 5.56 & 11.11 & 5.56 & 16.67 & 22.22 & 11.11 & 27.78 & 100.00 \\
\hline $\begin{array}{l}\text { Physical Capital InfrastructurelWater and } \\
\text { Sewer }\end{array}$ & 24.51 & 23.53 & 7.84 & 20.59 & 4.90 & 13.73 & 4.90 & 100.00 \\
\hline $\begin{array}{l}\text { Physical CapitalIInfrastructurelStreet } \\
\text { Lights and Signals }\end{array}$ & 3.77 & 8.49 & 16.98 & 24.53 & 24.53 & 18.87 & 2.83 & 100.00 \\
\hline Physical Capital\InfrastructurelSidewalks & 10.89 & 16.83 & 9.90 & 18.81 & 10.89 & 14.85 & 17.82 & 100.00 \\
\hline Physical Capital|Infrastructure\Parking & 11.63 & 14.73 & 12.40 & 18.60 & 17.05 & 10.85 & 14.73 & 100.00 \\
\hline $\begin{array}{l}\text { Physical Capital Infrastructure } \backslash \text { Roads, } \\
\text { bridges, and alleys }\end{array}$ & 6.87 & 13.74 & 14.07 & 23.45 & 19.60 & 9.55 & 12.73 & 100.00 \\
\hline Physical CapitallProperty & 50.00 & 3.85 & 11.54 & 0.00 & 0.00 & 3.85 & 30.77 & 100.00 \\
\hline Capital\Property\Zoning & 3.11 & 15.03 & 11.40 & 24.35 & 10.88 & 6.74 & 28.50 & 100.00 \\
\hline I Capital\Property\Annexation & 18.18 & 72.73 & 0.00 & 0.00 & 9.09 & 0.00 & 0.00 & 100.00 \\
\hline Physical Capital\Property\Buildings & 7.17 & 11.95 & 11.16 & 16.33 & 17.53 & 23.11 & 12.75 & 100.00 \\
\hline $\begin{array}{l}\text { Physical } \\
\text { Capital } \backslash \text { Property\Buildings } \backslash \text { School } \\
\text { Building }\end{array}$ & 18.97 & 32.76 & 8.62 & 37.93 & 1.72 & 0.00 & 0.00 & 100.00 \\
\hline $\begin{array}{l}\text { Physical } \\
\text { Capital\Property\Buildings\Sanford Center }\end{array}$ & 0.00 & 0.00 & 0.00 & 0.00 & 70.37 & 11.11 & 18.52 & 100.00 \\
\hline $\begin{array}{l}\text { Physical Capital|Property\Buildings } \backslash \text { Strand } \\
\text { Theater }\end{array}$ & 0.00 & 0.00 & 0.00 & 25.00 & 50.00 & 0.00 & 25.00 & 100.00 \\
\hline $\begin{array}{l}\text { Physical } \\
\text { Capital\Property\Buildings\Moundsville } \\
\text { Prison }\end{array}$ & 0.00 & 0.00 & 0.00 & 28.57 & 42.86 & 0.00 & 28.57 & 100.00 \\
\hline $\begin{array}{l}\text { Physical } \\
\text { Capital|Property\Buildings\Fostoria }\end{array}$ & 1.52 & 9.09 & 12.12 & 25.76 & 26.52 & 11.36 & 13.64 & 100.00 \\
\hline $\begin{array}{l}\text { Physical } \\
\text { Capital\Property\Buildings } \backslash \text { Property } \\
\text { Nuisance }\end{array}$ & 5.64 & 14.29 & 18.05 & 18.05 & 18.42 & 13.16 & 12.41 & 100.00 \\
\hline $\begin{array}{l}\text { Physical } \\
\text { Capital\Property\Buildings } \backslash \text { Housing }\end{array}$ & 4.76 & 4.76 & 11.56 & 12.93 & 29.25 & 15.65 & 21.09 & 100.00 \\
\hline $\begin{array}{l}\text { Physical } \\
\text { Capital\Property\Buildings } \backslash \text { Housing } \backslash \text { Traile } \\
\text { rs, Campers, RVs }\end{array}$ & 5.63 & 9.86 & 14.08 & 5.63 & 4.23 & 16.90 & 43.66 & 100.00 \\
\hline $\begin{array}{l}\text { Physical } \\
\text { Capital\Property\Buildings\Housing\Dilapi } \\
\text { dated Aging or Vacant Structures }\end{array}$ & 2.07 & 19.69 & 10.88 & 12.95 & 22.28 & 12.95 & 19.17 & 100.00 \\
\hline Physical Capital $\backslash$ Decorations & 0.00 & 0.00 & 0.00 & 0.00 & 0.00 & 60.00 & 40.00 & 100.00 \\
\hline Physical Capital\Debris & 0.00 & 10.53 & 19.30 & 17.54 & 15.79 & 24.56 & 12.28 & 100.00 \\
\hline Physical Capital\Vehicles and Equipment & 0.00 & 4.22 & 11.39 & 21.94 & 28.69 & 13.92 & 19.83 & 100.00 \\
\hline Physical Capital\Technology & 0.00 & 3.17 & 11.11 & 38.10 & 9.52 & 9.52 & 28.57 & 100.00 \\
\hline Physical Capital\Parks & 0.63 & 17.50 & 15.00 & 6.25 & 26.25 & 10.63 & 23.75 & 100.00 \\
\hline Physical Capital\Trails & 5.56 & 16.67 & 22.22 & 16.67 & 27.78 & 0.00 & 11.11 & 100.00 \\
\hline SUM & 7.65 & 13.38 & 12.41 & 18.79 & 19.29 & 12.35 & 16.12 & 100.00 \\
\hline $\mathrm{N}$ (Documents) & 21 & 21 & 21 & 22 & 23 & $* 12$ & 21 & 0 \\
\hline
\end{tabular}


With a boom, it is only rational to infer an increase in population for Moundsville. However, many of these new residents are more than likely temporary, (see Figure 32), judging by the numerous portable toilets and campers.

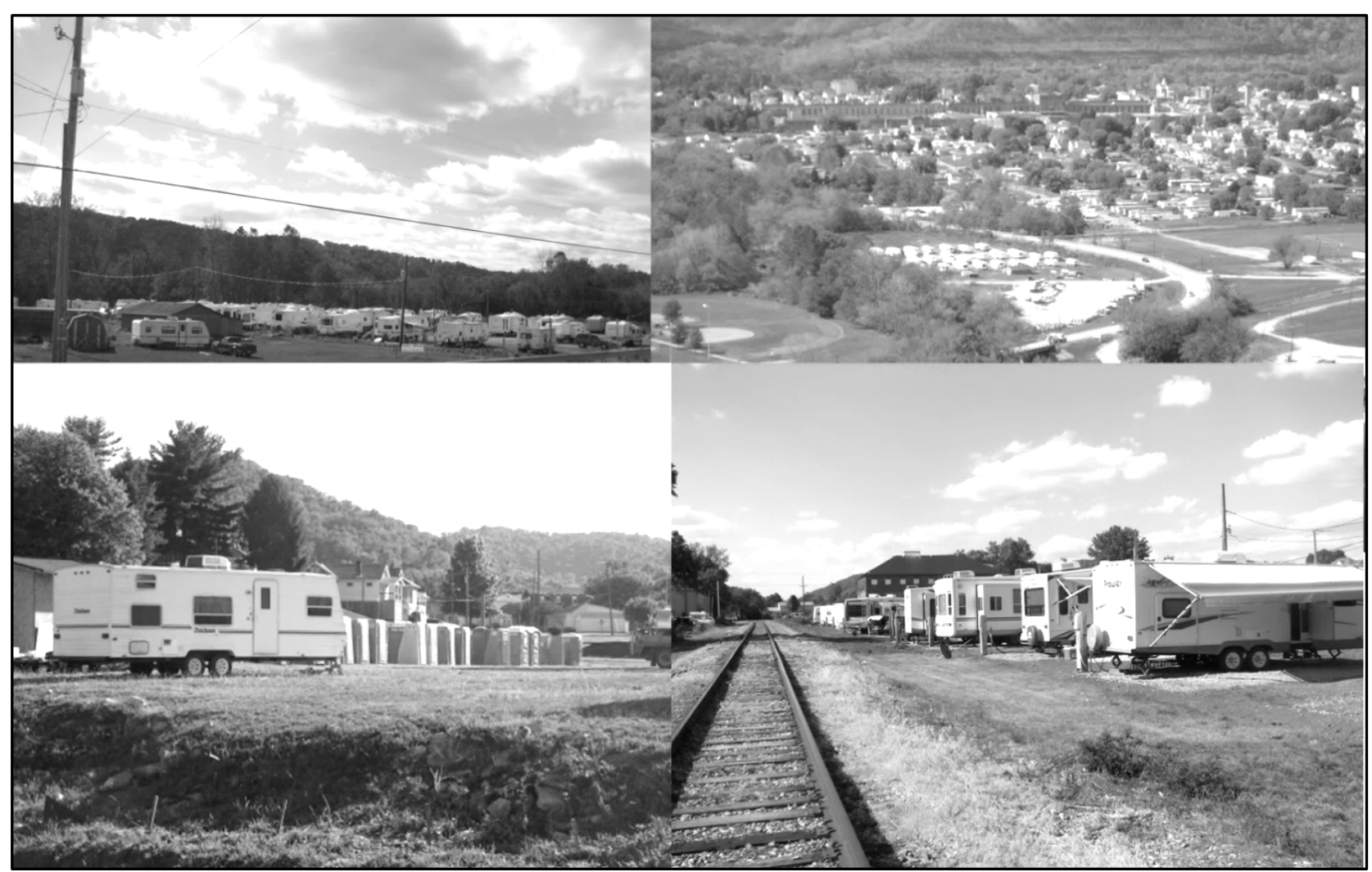

Figure 32. Portable Toilets and Campers Resulting from the Boom in Natural Gas, Moundsville. Kiger, B. (Photographer), 2012.

While a participant observer, a “camper count” was conducted that revealed numerous transient workers and or in some cases families. Furthermore, I discovered that the Marshall County Assessor's Office does not collect data on 'campers'. They collect data for tax purposes only which at the time did not apply to these transient workers. Data is not collected on units that are owned by out-of-state residents nor is it collected on residential units that are being rented out to businesses. 
Table 7

Moundsville City Limits Camper Count as of Aug. 15, 2012

\begin{tabular}{|l|c|}
\hline \multicolumn{1}{|c|}{ Location } & Camper Count \\
\hline Marshall County Fair Grounds & 43 \\
\hline 12 St. Across from Fairgrounds & 30 \\
\hline Pearl St. & 12 \\
\hline Varlas & 42 \\
\hline Marshall County Co-Op & 10 \\
\hline Across from CO-OP behind storage units and railroad tracks & 9 \\
\hline Unanimous Resident & 12 \\
\hline Small Lot between 4th street and Maxwell & 6 \\
\hline & Total \\
\hline
\end{tabular}

Data retrieved via participant observation activities contact. Note: Counts are fluid and are subject to change daily.

With this boom, most tend to only focus on the drilling portion, but in actuality, this is but only a small fraction of the entire energy system. There are huge investments in infrastructure needed to transport the gas. Furthermore, most of the jobs created in this boom involves the construction and maintaining of these pipelines. Figure 33 illustrates both the natural gas lines (blue) and the hazardous liquid pipelines (red). Using an open access tool provided by the Pipeline and Hazardous Materials Safety Administration (PHMSA), we are able to calculate the total approximate pipelines in both hazardous liquids and gas pipelines to be at a minimum 210 miles. It should be noted, this map only reveals the transmission lines and not the gathering or distribution lines needed for delivery to a resident's home and/or business.

Furthermore, when Dominion Resources finishes the \$500 million natural gas processing facility “Blue Racer” in Marshall County, an additional 110 miles of 20 inch, 24 inch and 30 inch diameter pipeline will be added between this plant and Pennsylvania, as well as four new gas compressor stations that adds approximately 17,000 horsepower. 


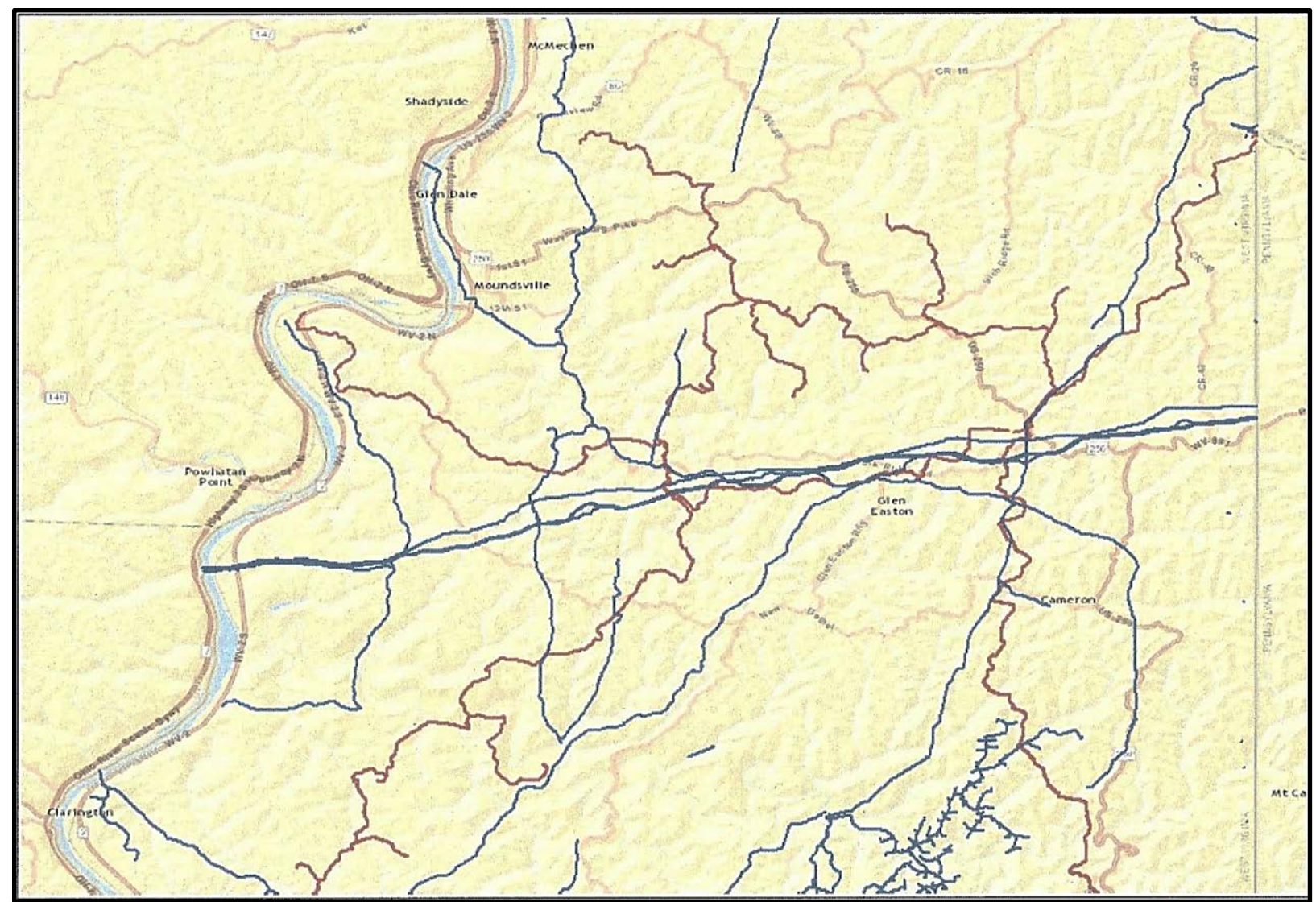

Figure 33. Marshall County Gas and Hazardous Pipelines. Map produced by NPMS Public Viewer tool at www.npms.phmsa.dot.gov. Note: Pipelines depicted on this map represent gas transmission and hazardous liquid lines only. 


\section{Human Capital}

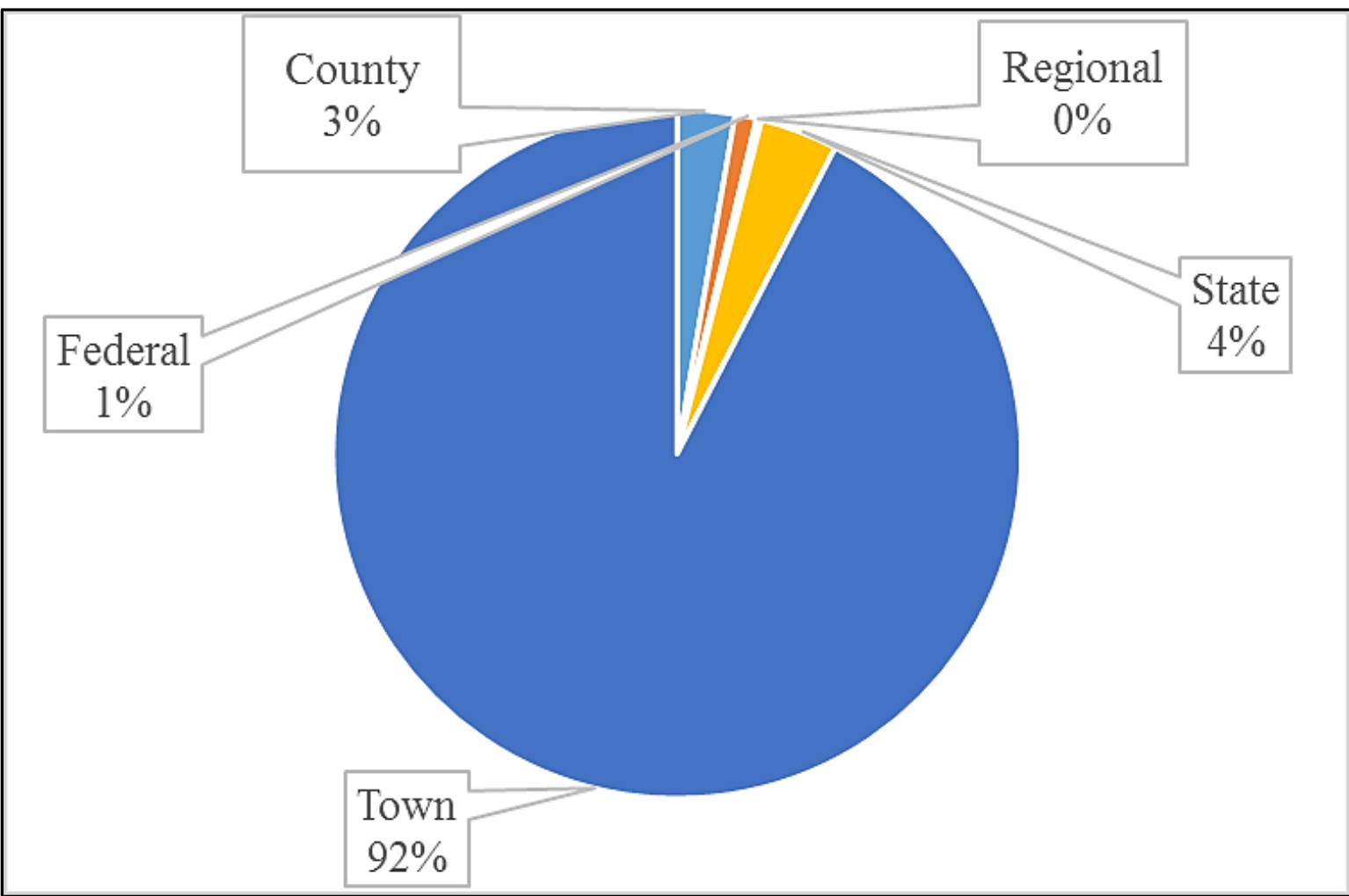

Figure 34. MAXQDA Results Total Percent Proportion of Human Capital with Primary Subcodes.

The process for coding human capital is informed via the potential indicators from the ERR Template. As revealed in previous literature, human capital primarily consists of a society’s education, skills, diversity, freedoms, competence, innovation etc.-most of which is intangible and difficult to measure. There was much difficulty in coding human capital because practically everything involves humans_our ideas, decision-making, concerns, reasoning, emotions etc., and it is not practical or perhaps valid to mark everything as human capital. For purposes in narrowing this view, the codes were broken by categories of stakeholders. As expected, the most commonly coded stakeholder was the community itself (92\%). Obviously, this is primarily due to the fact that the stakeholders who are going to be at city council meetings are the people themselves and staff/employees of the city. 
In exploring the human capital of the Moundsville Knowledge Base, several good indicators, (but certainly not an exhaustive list) include education, active labor force (ages 1865), job growth rate, income, and creativity/innovation.

Previous literature has noted one of the most observable elements in a boomtown is the in-migration of populations representing either individual or companies in hopes of increasing their wealth. Figure 35 reveals this concept of boom and bust in terms of population dynamics comparing Moundsville and Marshall County. Peaks in red, reveals extreme cases (especially at the county level) of rising and then falling over a period of a few or couple decades. What is of most concern, as of 2010, the population of Marshall County and Moundsville is seeing a continuous decrease in population—representing the community's lowest level since the 1920's.

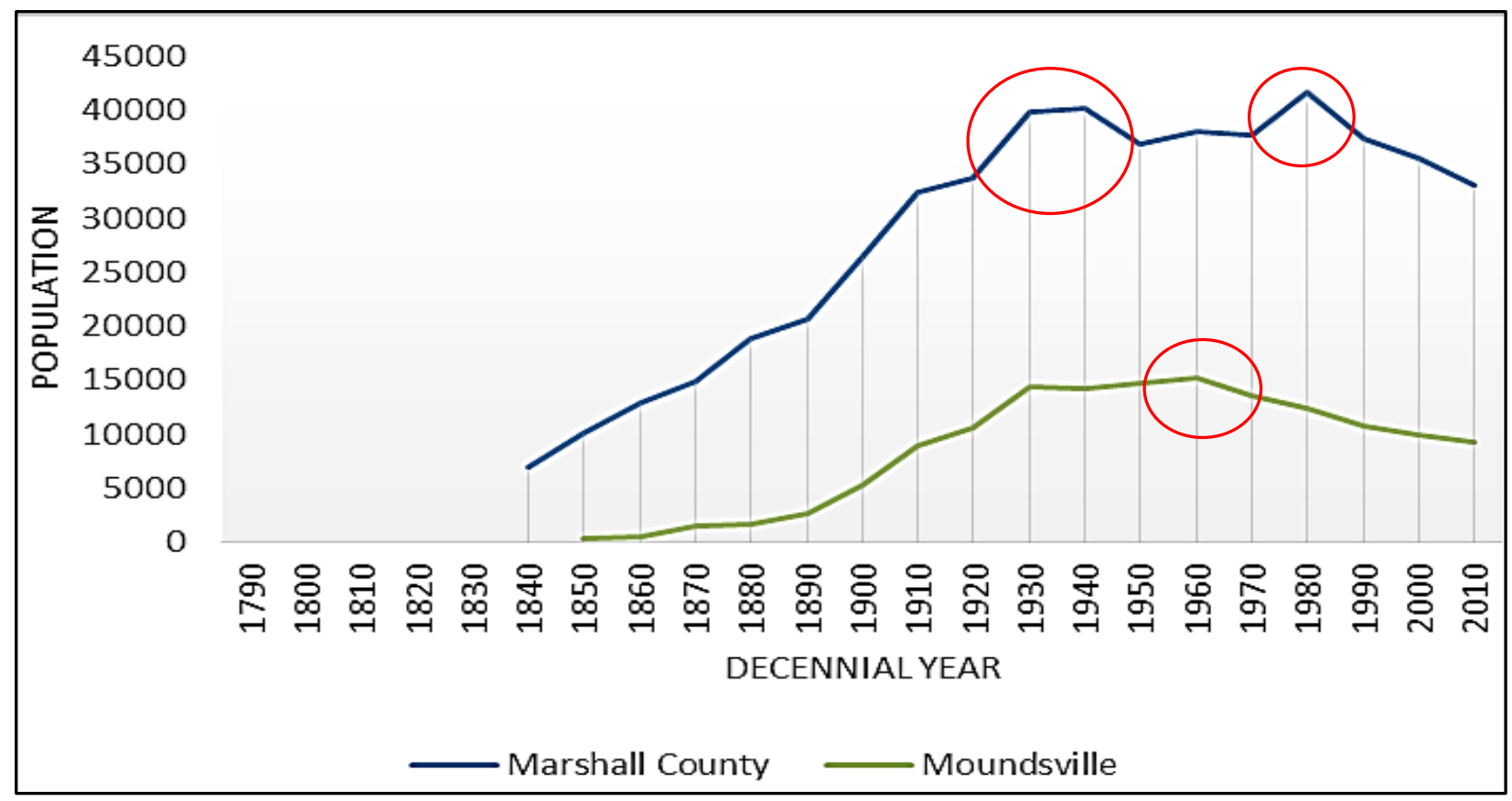

Figure 35. Population Boom and Bust in Marshall County and Moundsville. Data retrieved from http://www.census.gov/prod/www/decennial.html.

The population data suggests although the community and county alike are going through an energy boom, the population continues to decline. However, it seems the population decline in Moundsville has slowed, although still a negative percent change. This contradicts previous 
boomtown research and is surprising considering the how capital intensive the energy industry and typically establish a large pool of skilled labor in the process of setting up extraction sites. Furthermore, it should be noted, the transient workers are not likely included in these population estimates because these workers are not establishing residency and contributing to the tax base. Table 8

Population Percent Change Comparison

\begin{tabular}{|l|c|c|c|c|c|}
\hline \multicolumn{1}{|c|}{ Population Change } & Moundsville & $\begin{array}{c}\text { Marshall } \\
\text { County }\end{array}$ & $\begin{array}{c}\text { Rank in } \\
\text { State (55 } \\
\text { Counties) }\end{array}$ & $\begin{array}{c}\text { West } \\
\text { Virginia }\end{array}$ & $\begin{array}{c}\text { US } \\
\text { Rank }\end{array}$ \\
\hline Growth \% since 2010 Census to 2013 & -4.6 & -2 & 42 & 0.1 & 47 \\
\hline Growth \% since 2000 Census to 2013 & -11.1 & -8.6 & NA & 2.5 & NA \\
\hline 2000 to 2010\% Change & -6.8 & -6.8 & 51 & 2.5 & 47 \\
\hline 1990 to 2010\% Change & -13.3 & -11.4 & 47 & 3.3 & 50 \\
\hline 1980 to 2010\% Change & -25 & -20.4 & 47 & -5 & 50 \\
\hline
\end{tabular}

Data retrieved from StatsAmerica.org using Counties in Profile tool. Moundsville data derived from http://www.census.gov/prod/www/decennial.html.

Moundsville and West Virginia are continuing to see an outmigration of young professionals and an ever increasing median age currently at 46.5. Compare this to a US population where the median age is 37.6. This population decline feeds into a downward spiral in loss of tax revenue and human capital. Furthermore, the percent of those with a bachelor's degree or more is much less in Moundsville (11.3\%) compared to the U.S. (28.8\%) and where West Virginia ranks last out of all states. This suggests an outmigration of the most educated in the community of Moundsville and state of West Virginia. 
Table 9

Population Demographics Comparison

\begin{tabular}{|l|c|c|c|c|c|c|}
\hline Population Key Figures & $\begin{array}{c}\text { Moundsville } \\
\text { (2013 ACS } \\
\text { 5-year) }\end{array}$ & $\begin{array}{c}\text { Marshall } \\
\text { County } \\
2013\end{array}$ & $\begin{array}{c}\text { West } \\
\text { Virginia } \\
2013\end{array}$ & $\begin{array}{c}\text { Marshall } \\
\text { County } \\
\text { within WV } \\
\text { (Rank out of } \\
\text { 55 Counties) }\end{array}$ & US 2013 & $\begin{array}{c}\text { WV } \\
\text { within } \\
\text { US } \\
\text { Rank }\end{array}$ \\
\hline Total Population & 9,048 & 32,459 & $1,854,304$ & 18 & $316,128,839$ & 38 \\
\hline Median Age & 46.5 & 44.7 & 41.9 & 18 & 37.6 & 4 \\
\hline $\begin{array}{l}\text { H.S. Diploma or More - } \\
\text { \% of Adults 25+ (2013 } \\
\text { ACS 5 yr.) }\end{array}$ & 86.6 & 88.1 & 83.9 & 7 & 86 & 43 \\
\hline $\begin{array}{l}\text { Bachelor's Deg. Or } \\
\text { More - \% of Adults 25+ } \\
\text { (2013 ACS 5yr) }\end{array}$ & 11.3 & 14 & 18.9 & 25 & 28.8 & 51 \\
\hline $\begin{array}{l}\text { Median Household } \\
\text { Income }\end{array}$ & $\$ 33,234$ & $\$ 41,583$ & $\$ 41,195$ & 12 & $\$ 53,046$ & 49 \\
\hline Poverty Rate \% & 21.2 & 16.9 & 18.4 & 40 & 11 & 11 \\
\hline Gender Female \% & 51.7 & 50.9 & 50.6 & NA & 50.8 & NA \\
\hline White Alone \% & 95.1 & 97.7 & 93.8 & 18 & 77.7 & 36 \\
\hline
\end{tabular}

Data retrieved from U.S. Census Bureau using “Counties in Profile” tool by StatsAmerica.org. Data Source: 2009-2013 American Community Survey.

Quality of life positively correlates with wealth, thus a reasonable indicator is to observe the median household income. From a citizen's perspective, the clear winners in a boom are those who own many acres of land. However, this may only be the case if the landowner owns both the surface rights and the mineral rights. In the past it was common practice to sever the mineral rights from the surface rights. This therefore limits the amount of economic gain for today's surface owners in West Virginia. Furthermore, there is a lag in time when exploring the effects on median household income due to many factors including a delay for these wells to begin producing gas for the marketplace and a delay in severance tax distribution to the county and community levels.

The initial boom brings with it a wide range of companies both small and large. There are approximately eighty different oil and natural gas companies engaged in a direct role in West Virginia’s shale play (WVGES). However, approximately thirteen companies have a stake in 
76\% of the overall completed wells (calculated via ArcGis, WVGES, Oil and Gas Well Data). Most of the major players are out-of-state companies including Chesapeake Energy (Oklahoma), Cabot Oil \& Gas Corp. (Texas), and Antero Resources Corp. (Colorado). Furthermore, Chesapeake, Antero Resources and EQT combined produce $84 \%$ of the state's total shale gas production (calculated via ArcGis, WVGES, Oil and Gas Well Data). These companies do have regional offices; however, their headquarters are in other states which may have an effect on the amount of wealth staying in state and/or in these local communities. In Marshall County alone, the major producers include Chesapeake Energy, Chevron, Trans Energy, CNX, and Gastar.

These drilling companies can increase the economic wealth of the households through leases, bonus payments (typically \$200 - \$500/acre) and annual royalty payments to landowners in exchange for their drilling activities. Furthermore, signing bonuses for the Marcellus Shale Play have been documented to be as high as \$2,000 - \$2900 per acre (King, H.B. \& WVCBP, 2014). The royalty rates are based on production; so although landowners may have signed agreements for the lease of their minerals rights, it could be several years before any natural gas is produced. In fact, the initial signing bonus may be the only source of income a household may receive. Since royalties are based on the amount of natural gas produced - if a well is not producing, then there is no royalty.

West Virginia statute states this royalty rate to be at a minimum of 12.5 percent to 19 percent. In these agreements, typically known as "Memorandum of Oil and Gas Lease”, a mutual agreement is declared between landowner/Lessor and the energy company/Lessee for the lease of property in producing oil or gas. The initial primary term is typically set at five years with an additional five year option granted to the Lessee to extend. It is important to reiterate, the potential royalties for the landowner depend on if a gas well is producing. This can be greatly 
impacted by the price of natural gas. Even natural gas companies admit a gas well's production typically declines by 40\% in the first year alone (WVCBP, April, 2014) and economically recoverable gas production is uncertain beyond five years.

The Marshall County Assessor’s Office claims it has currently over 8,000 mineral accounts because of the recent boom in natural gas, however, data on royalties to landowners is not available, therefore limiting the ability to analyze the income from the natural wealth that would increase household wealth. Similar case studies (Wetzel County Case Study, WVCBP, 2014) have found this to be true and agree the overall economic impact of these lease and royalty payments is unclear. In addition, a case study of Wetzel County (neighbor to Marshall County) observes, "More than 25\% of active gas wells are on land controlled by two lumber companies, the state of West Virginia, a private university, and an energy company” (WVCBP, 2014, p. 4), thus again, limiting direct distribution of wealth to the individual households.

Local citizens also hope for an increase in job growth. It is intuitive to think there would be an overall job increase for the local community; however, it has been observed from previous studies that the opposite tends to be true in providing oil and gas jobs. In a recent case study by the West Virginia Center on Budget and Policy (WVCBP) — a neighboring county to Marshall (Wetzel), many oil and gas jobs are going to out-of-state workers where the industry tends to be more developed and/or the workers are more skilled. It was also observed when oil and gas companies were asked why more of the local population has not been hired, they claim, “It is difficult to find local workers who can pass a drug test” (p. 6, 2014). However, it seems no one can truly validate this claim. While a participant observer, this claim by the natural gas industry was also purported by local Moundsville citizens. In previous case studies, local citizens who own businesses such as campgrounds, restaurants, and hotels have reported an increase in 
economic activity. This has been purported by Moundsville citizens; however, there is no data to validate this claim at this time.

In general, the local and state government is responsible for looking out for its citizens and to properly manage budgets, revenues, and safety. At the state level, a $5 \%$ severance tax is levied on the natural gas industry as well as oil, coal, limestone/sandstone, sand, gravel, and other natural resources. Furthermore, $5 \%$ of gross value for both natural gas and oil and 10\% of net tax is distributed to local governments (National Conference of State Legislatures, 2012). Due to the recent boom, there has been a drastic increase in business property valuations. Therefore, Marshall County commissioners have been able to lower the levy rates five of the past eight years (as of 2014). In fact, the Marshall County Assessor reported values of real and personal property in the county has increased by $\$ 577.2$ million, excluding the public utility values, and forecasts a "total taxable assessed value of all property in Marshall County to be approximately \$2.7 billion”_essentially doubling since 2007 (The State Journal, Feb., 2013).

Local governments in West Virginia depend on revenue from property taxes. The Marshall County Assessor states, approximately 76 cents of every dollar paid on a property tax bill goes to the Board of Education, 18 cents to the County Commission, and 6 cents to the Cities. The Marshall County Board of Education received over \$11 Million primarily due to increasing property tax revenue over the past two years. In general, this is a good example in how natural capital may be converting to human capital—where increasing revenue from increasing property taxed as a result from the natural gas boom is received by the Board of Education. An assumption is made, the revenue that is allocated to the Board of Education will in return be spent on education or human capital or perhaps even maintaining physical capital (school buildings). 
Table 10 highlights the most direct economic impact at the state level (severance taxes) from the recent natural gas boom. However, there seems to be a rather contentious dynamic between county, community, and state officials as to how best to distribute the money from this natural wealth. A recent article reveals the sentiment and complexity, "Marshall County’s share of oil and gas severance tax revenue has increased by more than $\$ 358,000$ during the past three years, but none of that money will be used to work on roads, county officials said” (Hanson, March 20, 2014). And in another article points to an issue with funds being held up for distribution to counties causing county budgets to fall short. "Marshall County Commission believes state officials are withholding about 1.6 million worth of severance tax revenue for coal, oil and natural gas - a development that may lead the county into a shortfall at the end of the fiscal 2014 year”. The commissioner then states, “I don’t know how we can tell our constituents that, here we are in the middle of the Marcellus shale, and we don't have any oil and gas severance money” (Junkins, July 9, 2014). 
Table 10

\begin{tabular}{|c|c|c|c|c|c|c|c|c|}
\hline Item & 2013 & 2012 & 2011 & 2010 & 2009 & 2008 & 2007 & 2006 \\
\hline Total Revenue & $\$ 14,581,453$ & $\$ 13,247,295$ & $\$ 15,397,630$ & $\$ 13,712,959$ & $\$ 11,112,547$ & $\$ 10,736,112$ & $\$ 12,525,048$ & $\$ 11,435,036$ \\
\hline General Revenue & $\$ 12,390,766$ & $\$ 12,294,552$ & $\$ 12,714,234$ & $\$ 11,709,919$ & $\$ 11,113,125$ & $\$ 10,766,289$ & $\$ 10,631,568$ & $\$ 10,262,195$ \\
\hline Intergovernmental Revenue & $\$ 4,325,052$ & $\$ 4,359,169$ & $\$ 4,748,528$ & $\$ 4,426,116$ & $\$ 3,775,786$ & $\$ 3,274,439$ & $\$ 3,256,627$ & $\$ \quad 3,234,430$ \\
\hline From Federal & $\$ 4,230,663$ & $\$ 4,267,399$ & & & & & & \\
\hline From Local & 94,389 & 91,770 & & & & & & \\
\hline Total Taxes & $\$ 5,378,122$ & $\$ 5,285,773$ & $\$ 5,210,925$ & $\$ 4,803,704$ & $\$ 4,787,352$ & $\$ 4,881,908$ & $\$ 4,642,230$ & $\$ \quad 4,547,929$ \\
\hline General Sales and Gross Receipts Taxes & $\$ 1,255,377$ & $\$ 1,277,328$ & $\$ 1,210,255$ & $\$ 1,156,513$ & $\$ 1,110,017$ & $\$ 1,109,822$ & \$ $1,129,531$ & $\$ \quad 1,125,766$ \\
\hline Selective Sales and Gross Receipts Taxes & $\$ 1,323,634$ & $\$ 1,282,258$ & $\$ 1,277,362$ & $\$ 1,184,510$ & $\$ 1,116,306$ & $\$ 1,157,069$ & $\$ 1,083,810$ & $\$ \quad 1,051,436$ \\
\hline License Taxes & $\$ \quad 137,437$ & 137,670 & $\$ \quad 150,029$ & $\$ \quad 143,456$ & $\$ \quad 192,985$ & $\$ \quad 193,468$ & $\$ \quad 184,370$ & 185,432 \\
\hline Individual Income Taxes & $\$ 1,795,947$ & $\$ 1,755,746$ & $\$ 1,665,885$ & $\$ 1,521,895$ & $\$ 1,557,403$ & $\$ 1,518,746$ & $\$ 1,360,511$ & $1,297,720$ \\
\hline Corporation Net Income Taxes & 242,429 & 192,385 & $\$ \quad 307,278$ & $\$ 237,159$ & $\$ \quad 420,530$ & 538,839 & $\$ 539,136$ & 533,027 \\
\hline Severance Tax* & $\$ \quad 608,371$ & 626,203 & $\$ \quad 440,875$ & $\$ \quad 400,591$ & $\$ \quad 359,578$ & $\$ \quad 338,177$ & $\$ 312,246$ & 314,727 \\
\hline All Other Taxes * & 14,927 & 14,183 & $\$ \quad 159,241$ & $\$ \quad 159,580$ & 30,533 & 25,787 & 32,626 & 39,821 \\
\hline Current Charges & $\$ 1,504,885$ & $\$ 1,406,361$ & $\$ 1,483,565$ & $\$ 1,318,893$ & $\$ 1,343,499$ & $\$ 1,279,211$ & $\$ 1,232,116$ & $1,100,687$ \\
\hline Miscellaneous General Revenue & $\$ 1,182,707$ & $\$ 1,243,249$ & $\$ 1,271,216$ & $\$ 1,161,206$ & $\$ 1,206,488$ & $\$ 1,330,731$ & $\$ 1,500,595$ & $1,379,149$ \\
\hline Utility Revenue & 2,435 & 2,906 & 2,108 & 2,272 & 439 & 362 & 544 & 421 \\
\hline Liquor Stores Revenue & 90,403 & 88,321 & 84,268 & 79,614 & 80,497 & 74,508 & 69,729 & 66,036 \\
\hline Insurance Trust Revenue & $\$ 2,097,849$ & 861,516 & $\$ 2,597,020$ & $\$ 1,921,154$ & $\$ \quad(81,514)$ & $\$ \quad(105,047)$ & $\$ 1,823,207$ & $\$ \quad 1,106,384$ \\
\hline Unemployment Compensation Systems & 3,022 & 237,208 & & & & & & \\
\hline State-Administered Pension Systems & $\$ 2,090,972$ & 530,477 & & & & & & \\
\hline Workers' Compensation Systems & 3,855 & 93,831 & & & & & & \\
\hline Total Expenditure & $\$ 13,234,155$ & $\$ 13,222,912$ & $\$ 13,000,033$ & $\$ 12,343,051$ & $\$ 11,501,520$ & $\$ 10,561,575$ & $\$ 10,165,499$ & $\$ \quad 9,781,296$ \\
\hline Intergovernmental Expenditure & $\$ 2,469,535$ & $\$ 2,618,032$ & $\$ 2,533,582$ & $\$ 2,382,633$ & $\$ 2,232,558$ & $\$ 2,131,100$ & $\$ 2,074,429$ & $\$ \quad 2,067,829$ \\
\hline Direct Expenditure & $\$ 10,764,620$ & $\$ 10,604,880$ & $\$ 10,466,451$ & $\$ 9,960,418$ & $\$ 9,268,962$ & $\$ 8,430,475$ & $\$ 8,091,070$ & $\$ \quad 7,713,467$ \\
\hline Current Operations & $\$ 7,755,238$ & $\$ 7,477,840$ & $\$ 7,372,142$ & $\$ 6,984,904$ & $\$ 6,696,595$ & $\$ 6,265,863$ & $\$ 5,962,561$ & $\$ \quad 5,874,295$ \\
\hline Capital Outlay & $\$ 1,074,774$ & $\$ 1,213,167$ & $\$ 1,100,556$ & $\$ 1,004,272$ & $\$ 1,094,253$ & $\$ \quad 893,891$ & $\$ 943,538$ & 935,262 \\
\hline Insurance Benefits and Repayments & $\$ 1,446,341$ & $\$ 1,436,585$ & $\$ 1,480,834$ & $\$ 1,505,492$ & $\$ 1,047,745$ & $\$ \quad 851,629$ & $\$ 847,501$ & 521,608 \\
\hline Assistance and Subsidies & $\$ 234,604$ & 226,909 & $\$ \quad 269,701$ & $\$ \quad 198,482$ & $\$ \quad 183,911$ & $\$ \quad 163,971$ & 161,837 & 157,607 \\
\hline Interest on Debt & $\$ 253,663$ & 250,379 & $\$ \quad 243,218$ & $\$ 267,268$ & $\$ \quad 246,458$ & $\$ \quad 255,121$ & $\$ \quad 175,633$ & 224,695 \\
\hline Exhibit: Salaries and Wages & $\$ 1,868,736$ & $\$ 1,832,088$ & $\$ 1,771,738$ & $\$ 1,731,700$ & $\$ 1,574,456$ & $\$ 1,441,006$ & $\$ 1,380,391$ & $1,335,625$ \\
\hline General Expenditure & $\$ 11,708,850$ & $\$ 11,709,303$ & $\$ 11,445,676$ & $\$ 10,767,434$ & $\$ 10,376,402$ & $\$ 9,634,090$ & \$ 9,246,817 & $\$ \quad 9,189,486$ \\
\hline Intergovernmental General Expenditure & $\$ 2,469,535$ & $\$ 2,618,032$ & $\$ 2,533,582$ & $\$ 2,382,633$ & $\$ 2,232,558$ & $\$ 2,131,100$ & $\$ 2,074,429$ & $\$ \quad 2,067,829$ \\
\hline Direct General Expenditure & $\$ 9,239,315$ & $\$ 9,091,271$ & $\$ 8,912,094$ & $\$ 8,384,801$ & $\$ 8,143,844$ & $\$ 7,502,990$ & $\$ 7,172,388$ & $\$ \quad 7,121,657$ \\
\hline & & & & & & & & \\
\hline \multicolumn{9}{|l|}{ General Expenditure, by Function: } \\
\hline Education & $\$ 4,333,893$ & $\$ 4,335,500$ & $\$ 4,161,900$ & $\$ 3,931,867$ & $\$ 3,892,978$ & $\$ 3,676,900$ & $\$ 3,572,629$ & $3,418,218$ \\
\hline Public Welfare & $\$ 3,526,796$ & $\$ 3,293,863$ & $\$ 3,287,709$ & $\$ 3,042,614$ & $\$ 2,860,952$ & $\$ 2,565,426$ & $\$ 2,434,315$ & $2,376,902$ \\
\hline Hospitals & $\$ \quad 126,185$ & 125,062 & $\$ \quad 120,540$ & $\$ \quad 121,617$ & $\$ \quad 114,021$ & $\$ \quad 106,482$ & 88,713 & 81,233 \\
\hline Health & $\$ 345,537$ & $\$ \quad 361,623$ & $\$ \quad 318,411$ & $\$ \quad 291,129$ & $\$ \quad 290,263$ & $\$ \quad 309,702$ & $\$ \quad 307,646$ & 300,750 \\
\hline Highways & $\$ 1,102,651$ & $\$ 1,217,378$ & $\$ 1,224,162$ & $\$ 1,157,005$ & $\$ 1,209,882$ & $\$ 1,015,587$ & $\$ \quad 975,292$ & $1,022,191$ \\
\hline Police Protection & 75,101 & 81,483 & $\$ \quad 76,036$ & 72,880 & $\$ \quad 101,691$ & 65,468 & 61,691 & 54,295 \\
\hline Correction & $\$ 300,693$ & 288,148 & $\$ \quad 275,564$ & $\$ \quad 270,717$ & $\$ \quad 256,169$ & $\$ 241,996$ & $\$ \quad 233,639$ & 214,702 \\
\hline Natural Resources & $\$ 225,833$ & $\$ \quad 260,494$ & $\$ \quad 227,838$ & $\$ 236,900$ & $\$ 187,066$ & $\$ \quad 170,496$ & $\$ \quad 178,911$ & 159,490 \\
\hline Parks and Recreation & 51,269 & 55,674 & $\$ \quad 60,557$ & 62,639 & $\$ \quad 55,731$ & 67,572 & 59,975 & 52,237 \\
\hline Governmental Administration & $\$ 438,545$ & 443,170 & $\$ \quad 418,183$ & $\$ 400,680$ & $\$ \quad 415,531$ & $\$ \quad 412,403$ & $\$ \quad 432,943$ & 553,033 \\
\hline Interest on General Debt & $\$ 253,663$ & 250,379 & $\$ \quad 243,218$ & $\$ 267,268$ & $\$ 246,458$ & $\$ \quad 255,121$ & $\$ \quad 175,633$ & 224,695 \\
\hline Other and Unallocable & $\$ 928,684$ & 996,529 & $\$ 1,031,558$ & $\$ 912,118$ & $\$ 745,660$ & $\$ 746,937$ & $\$ 725,430$ & 731,740 \\
\hline Utility Expenditure & 4,854 & 4,110 & 3,728 & 3,521 & $\$ \quad 10,128$ & 12,836 & 12,076 & 13,851 \\
\hline Liquor Stores Expenditure & 74,110 & 72,914 & $\$ \quad 69,795$ & $\$ \quad 66,604$ & $\$ \quad 67,245$ & 63,020 & 59,105 & 56,351 \\
\hline Insurance Trust Expenditure & $\$ 1,446,341$ & $\$ 1,436,585$ & $\$ 1,480,834$ & $\$ 1,505,492$ & $\$ 1,047,745$ & $\$ \quad 851,629$ & $\$ \quad 847,501$ & 521,608 \\
\hline Unemployment Compensation Systems & $\$ \quad 365,722$ & $\$ \quad 352,252$ & & & & & & \\
\hline State-Administered Pension Systems & $\$ 990,402$ & $\$ 955,411$ & & & & & & \\
\hline Workers' Compensation Systems & 90,217 & 128,922 & & & & & & \\
\hline Debt Outstanding, Long Term and Short Term & $\$ 7,355,630$ & $\$ 7,306,756$ & $\$ 7,406,254$ & $\$ 7,144,323$ & $\$ 6,501,995$ & $\$ 6,365,585$ & $\$ 5,628,065$ & $5,406,391$ \\
\hline Cash and Security Holdings & $\$ 21,396,404$ & $\$ 19,706,538$ & $\$ 20,305,005$ & $\$ 17,847,539$ & $\$ 16,208,457$ & $\$ 16,357,378$ & $\$ 15,726,138$ & $\$ 11,098,283$ \\
\hline
\end{tabular}

Retrieved from US Census Bureau Annual Survey of State Government Tax Collections. *Notes:

Severance tax amounts for 2012 and 2013 were retrieved from US Census Bureau Annual Survey while 2006-2011 were retrieved from TransparencyWV.org. In addition, severance tax amounts were subtracted from "All Other Taxes” accounts category for minimizing duplication error. 
Severance tax revenue from coal and natural gas has been on a steady incline both at the state level and for Marshall County. Unfortunately, the only available data at the county level was for FY 2011- FY 2013. In FY 2011, the county received \$71,161; FY 2012, 236,643; and FY 2013 \$429,810 (Junkins, July 9, 2014).

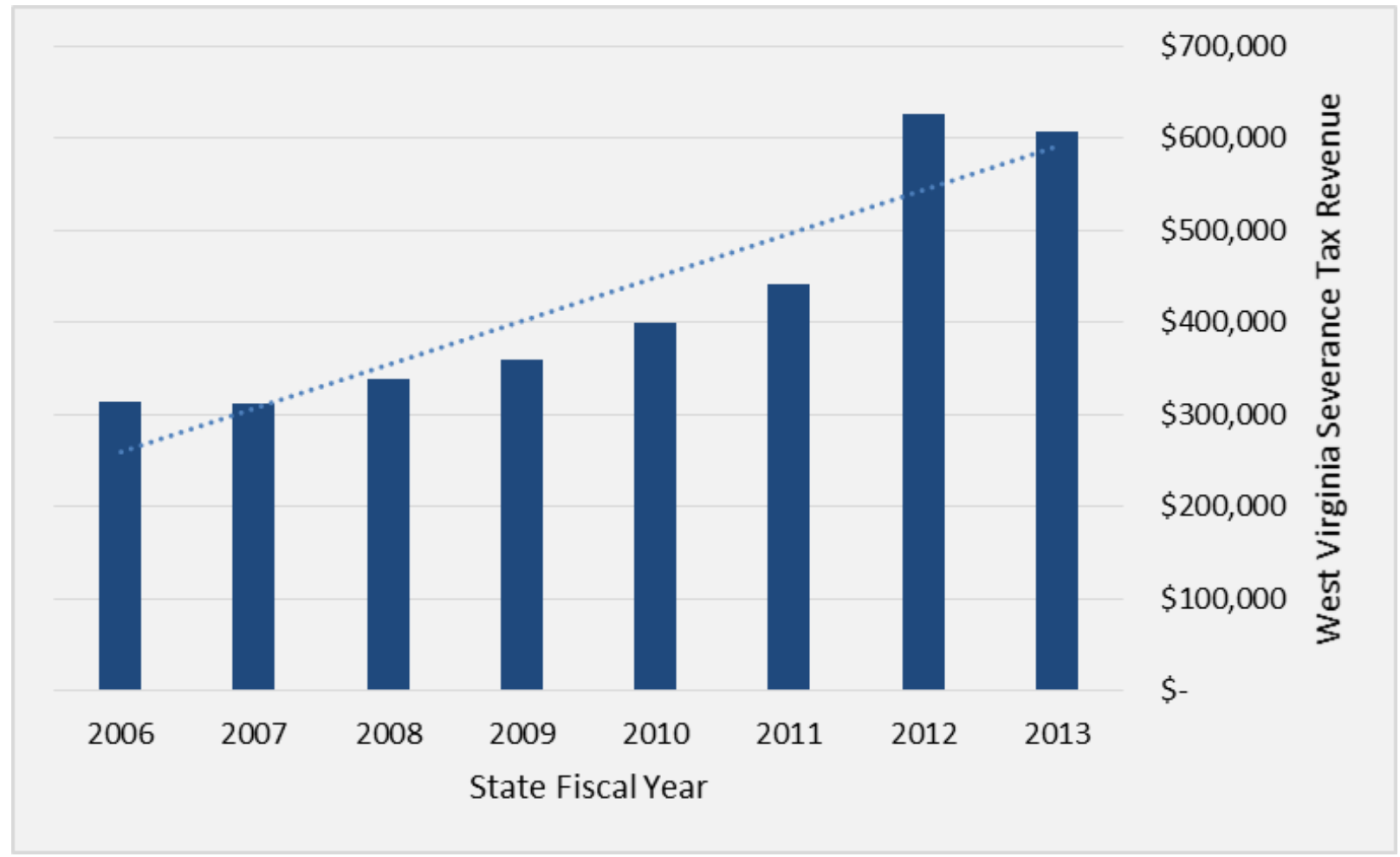

Figure 36. Severance Tax Revenue Trend in West Virginia (\$000). Data retrieved from US Census Bureau Annual Survey of State Government Tax Collections.*Notes: Severance tax amounts for 2012 and 2013 were retrieved from US Census Bureau Annual Survey while 2006-2011 were retrieved from TransparencyWV.org. In addition, Severance tax amounts were subtracted from “All Other Taxes” accounts category for minimizing duplication error.

Table 11 reveals the Location Quotient (LQ) change between years 2006 and 2012. What is most significant is the growth in the industrial cluster of "Energy (Fossil \& Renewable)". The NAICS definition of this cluster includes drilling for oil and natural gas, natural gas extraction etc... and many supporting industries such as pipeline transportation. An industry cluster is a group of similar industries closely connected by supply chains and/or similar labor pools located within the same region. A location quotient (LQ) measures how concentrated an industry cluster 
is in a given region as compared to the nation. An LQ greater than 1 means the cluster is an export industry. Industries with a high LQ are typically, but not always, export-oriented industries bringing money into the region rather than simply circulating money that is already in the region. An LQ of less than 1 means it typically has to import from outside to satisfy local demand.

Table 11

Industry Cluster LQ and Employment Comparison, 2006-2012 for Marshall County

\begin{tabular}{|c|c|c|c|c|c|}
\hline Description & $\begin{array}{c}\text { QCEW } \\
\text { Cluster - } \\
\text { Employment } \\
2006\end{array}$ & $\begin{array}{c}\text { Industry } \\
\text { Cluster } \\
\text { Employment } \\
\text { LQ } 2006\end{array}$ & $\begin{array}{c}\text { QCEW } \\
\text { Cluster - } \\
\text { Employment } \\
2012\end{array}$ & $\begin{array}{c}\text { Industry } \\
\text { Cluster } \\
\text { Employment } \\
\text { LQ } 2012\end{array}$ & $\begin{array}{l}\text { Change } \\
\text { in } \\
\text { Industry } \\
\text { Share }\end{array}$ \\
\hline $\begin{array}{l}\text { Chemicals \& Chemical } \\
\text { Based Products }\end{array}$ & 1,008 & 5.12 & 193 & 1.21 & -815 \\
\hline Advanced Materials & 1,101 & 2.47 & 303 & 0.84 & -798 \\
\hline $\begin{array}{l}\text { Education \& Knowledge } \\
\text { Creation }\end{array}$ & 356 & 0.93 & 215 & 0.51 & -141 \\
\hline $\begin{array}{l}\text { Biomedical/Biotechnical } \\
\text { (Life Sciences) }\end{array}$ & 1,115 & 1.04 & 1,010 & 0.83 & -105 \\
\hline Forest \& Wood Products & 280 & 1.75 & 204 & 1.97 & -76 \\
\hline Mining & 95 & 5.74 & 53 & 3.07 & -42 \\
\hline $\begin{array}{l}\text { Manufacturing } \\
\text { Supercluster }\end{array}$ & 186 & 0.34 & 145 & 0.35 & -41 \\
\hline $\begin{array}{l}\text { Fabricated Metal Product } \\
\text { Mfg. }\end{array}$ & 186 & 1.51 & 145 & 1.37 & -41 \\
\hline Defense \& Security & 333 & 0.59 & 295 & 0.48 & -38 \\
\hline $\begin{array}{l}\text { Agribusiness, Food } \\
\text { Processing \& Technology }\end{array}$ & 53 & 0.21 & 33 & 0.13 & -20 \\
\hline $\begin{array}{l}\text { Business \& Financial } \\
\text { Services }\end{array}$ & 227 & 0.24 & 211 & 0.21 & -16 \\
\hline Printing \& Publishing & 38 & 0.19 & 23 & 0.13 & -15 \\
\hline $\begin{array}{l}\text { Information Technology \& } \\
\text { Telecommunications }\end{array}$ & 32 & 0.07 & 19 & 0.04 & -13 \\
\hline $\begin{array}{l}\text { Arts, Entertainment, } \\
\text { Recreation \& Visitor } \\
\text { Industries }\end{array}$ & 107 & 0.25 & 122 & 0.28 & 15 \\
\hline Glass \& Ceramics & 8 & 0.3 & 70 & 3.63 & 62 \\
\hline Transportation \& Logistics & 116 & 0.35 & 190 & 0.56 & 74 \\
\hline $\begin{array}{l}\text { Energy (Fossil \& } \\
\text { Renewable) }\end{array}$ & 1,651 & 3.39 & 2,544 & 5.05 & 893 \\
\hline Apparel \& Textiles & 443 & 4.28 & $\mathrm{NC}$ & NC & NC \\
\hline Total All Industries & 10,984 & 1 & 11,130 & 1 & 146 \\
\hline
\end{tabular}

Data retrieved using statsamerica.org cluster analysis tool. Source: U.S. Bureau of Labor Statistics, Quarterly Census of Employment \& Wages (QCEW) and Purdue Center for Regional Development (cluster definitions). 
Finally, in exploring human capital, the StatsAmerica knowledge base tool 'innovation index’ is utilized. Although useful for local decision makers and economic developers, unfortunately, the tool lacks the ability to explore human capital at the community level. However, with Moundsville representing a similar demographic distribution and furthermore being the largest community in the county, one may predict the results to be similar.

The methodology used for this particular tool in calculating the human capital involves (1) the percent of adult population with some college or an associate's degree, 2012; (2) the percent of adult population with a bachelor's degree or higher, 2012; (3) the population growth rate of young adults ages 24-44 between the years 1997-2012; (4) the average high-tech employment share between 1997-2012; and (5) the technology-based knowledge occupations share of total employment for 2011. The aggregate of these indicators reveals a comparison for the human capital index between the United States, West Virginia, and Marshall County.

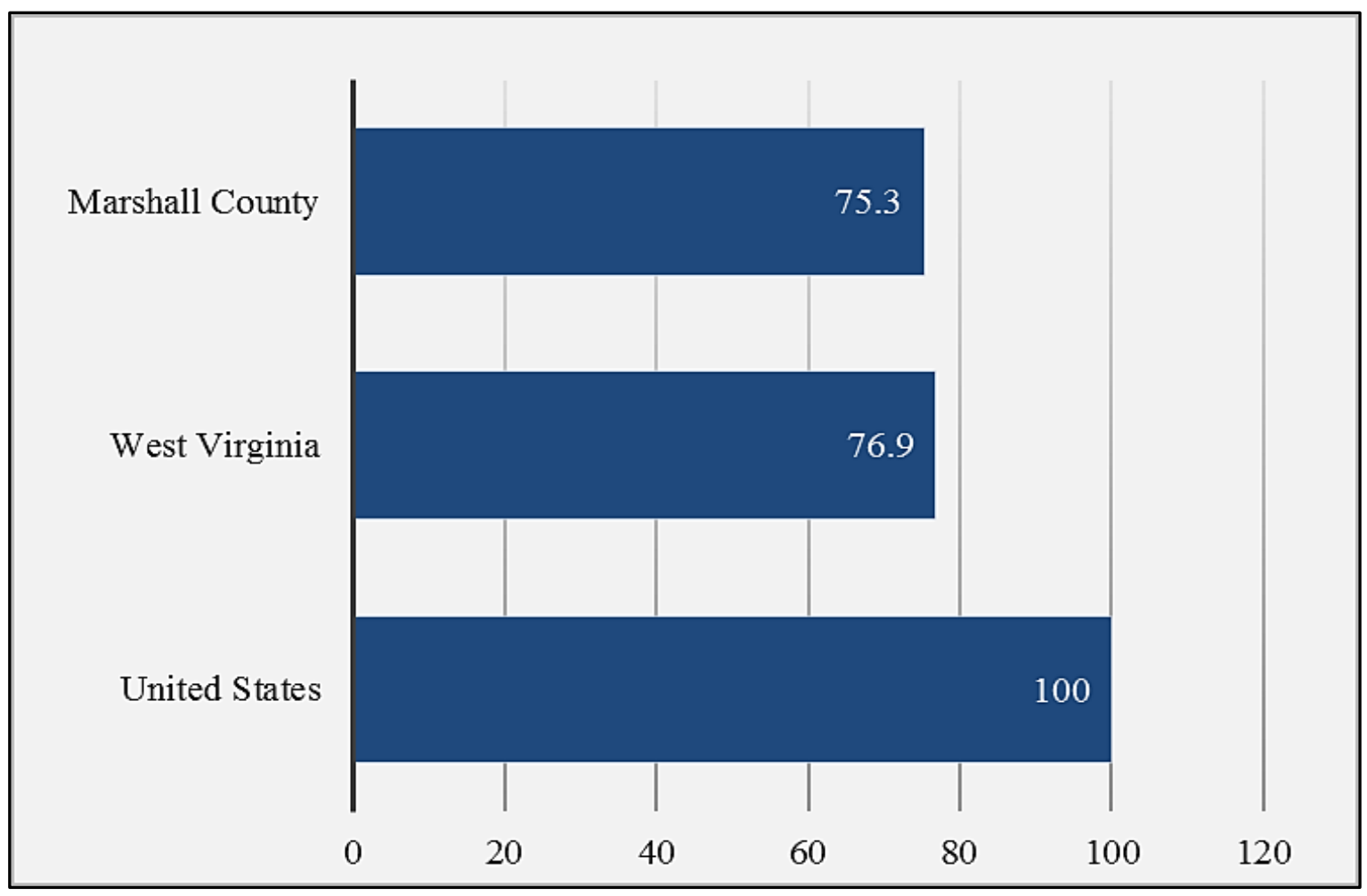

Figure 37. Human Capital Index for Marshall County. Data retrieved using the innovation index tool from http://www.statsamerica.org/innovation/innovation_index/region-select.html. 
In exploring the relationship between the boom in natural gas on the community of

Moundsville, a theme of codes emerge including the most obvious which are 'natural gas', 'natural gas company', and those that may be less obvious including 'transient workers', 'trailers, campers, and RVs', and finally, 'vehicles and equipment'. Once again, a cross tabs function with the assistance of MAXQDA is applied comparing the code system relating to natural gas to the variable of 'year'. Additionally, in order to observe the relationship that may exist between the codes of efficacy ('positive' and 'negative') and the key codes related to natural gas, a crosstab function is applied using the independent variable of 'year' (Table 12). In observing this table, it seems the coding of transient workers does not even appear until year 2011 which is 5 years after the first well was drilled in Marshall County.

Table 12

Time Series Analysis of Natural, Physical, and Human Capital Interplay with Natural Gas

\begin{tabular}{|c|c|c|c|c|c|c|c|c|}
\hline Code System & 2006 & 2007 & 2008 & 2009 & 2010 & 2011 & 2012 & SUM \\
\hline Natural Capital\natural gas & 2.50 & 2.50 & 5.00 & 5.00 & 45.00 & 15.00 & 25.00 & 100 \\
\hline $\begin{array}{l}\text { Human Capital\Town } \backslash \text { Economic } \\
\text { Development } \backslash \text { Corporations } \backslash \text { Natu } \\
\text { ral Gas Company }\end{array}$ & 0.00 & 0.00 & 0.00 & 2.56 & 74.36 & 0.00 & 23.08 & 100 \\
\hline $\begin{array}{l}\text { Human Capital\Town } \backslash \text { Economic } \\
\text { Development } \backslash \text { Corporations } \backslash \text { Natu } \\
\text { ral Gas Company } \backslash \text { Transient } \\
\text { Workers }\end{array}$ & 0.00 & 0.00 & 0.00 & 0.00 & 0.00 & 36.36 & 63.64 & 100 \\
\hline $\begin{array}{l}\text { Human } \\
\text { Capital } \backslash \text { Town } \backslash \text { Population } \backslash \text { Citizen } \\
\text { \Concerned Citizen }\end{array}$ & 11.27 & 21.10 & 14.16 & 20.81 & 13.01 & 4.91 & 14.74 & 100 \\
\hline Human Capital \negative & 4.35 & 13.04 & 17.28 & 16.82 & 18.65 & 13.04 & 16.82 & 100 \\
\hline Human Capital\positive & 8.11 & 12.17 & 15.62 & 23.53 & 15.62 & 10.14 & 14.81 & 100 \\
\hline $\begin{array}{l}\text { Physical } \\
\text { Capital } \backslash \text { Property } \backslash \text { Buildings } \backslash \text { Hous } \\
\text { ing } \backslash \text { Trailers, Campers, RVs }\end{array}$ & 5.63 & 9.86 & 14.08 & 5.63 & 4.23 & 16.90 & 43.66 & 100 \\
\hline $\begin{array}{l}\text { Physical Capital } \backslash \text { Vehicles and } \\
\text { Equipment }\end{array}$ & 0.00 & 4.22 & 11.39 & 21.94 & 28.69 & 13.92 & 19.83 & 100 \\
\hline SUM & 5.75 & 12.49 & 14.89 & 18.57 & 18.99 & 11.31 & 18.00 & 100 \\
\hline $\mathrm{N}$ (Documents) & 21 & 21 & 21 & 22 & 23 & $* 12$ & 21 & 0 \\
\hline
\end{tabular}

This adds support that the community has not properly integrated the stages of resource development into the planning process. Unfortunately, this decision to wait may hurt the community in the long-run allowing industry to take the lead instead of the community. 
Communities need to be reminded that energy companies are thinking thirty plus years in advance-and perhaps it would be advantageous for the community to plan this far in advance which may allow for a more positive post-resource outcome.

In Figure 38, crosstabs function is applied (x) year and (y) frequency of capital form. The results from applying this MAXQDA crosstabs function seem to suggest a small negative pattern for human capital and a small positive trend for both natural and physical capital, therefore inconclusive.

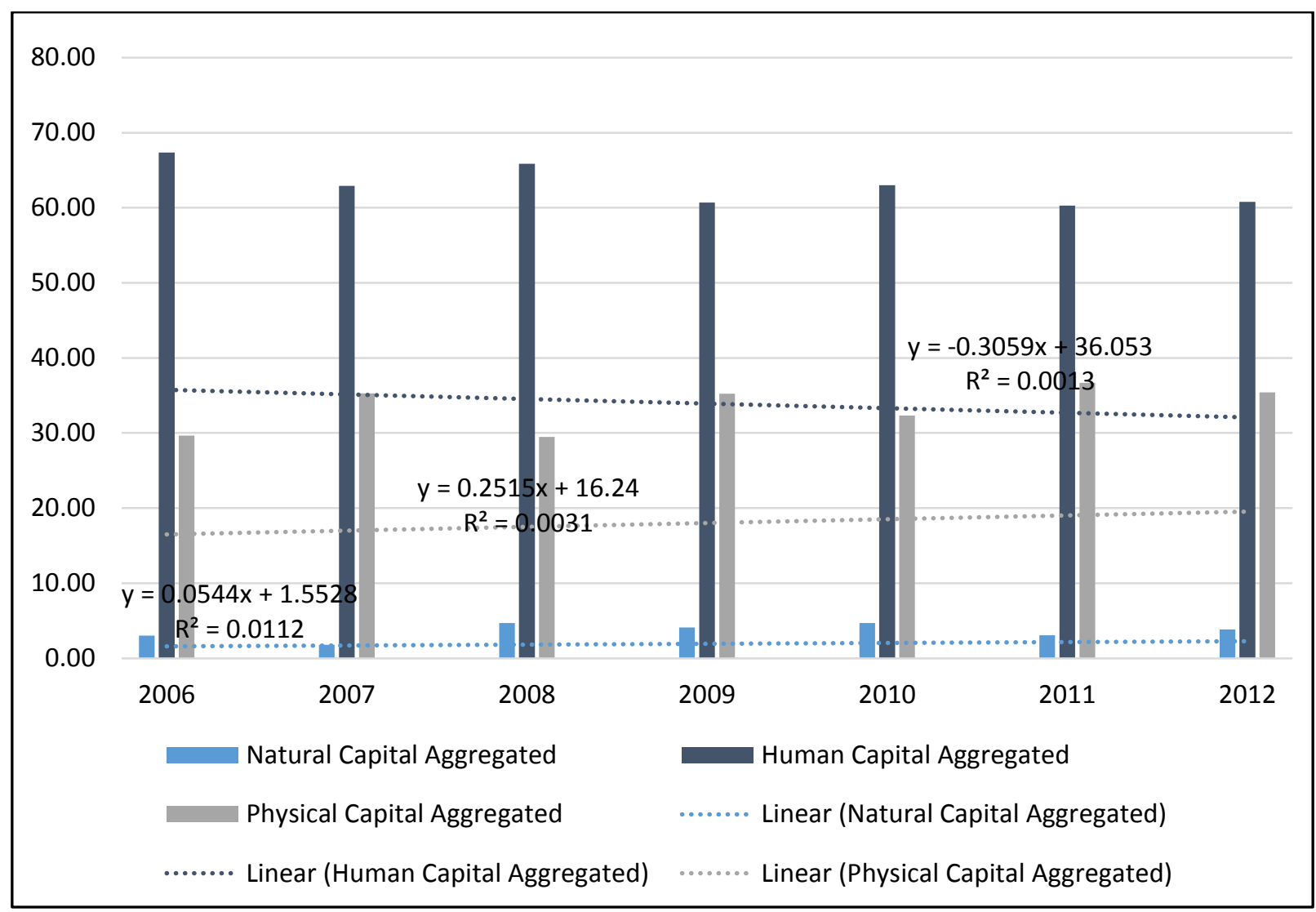

Figure 38. MAXQDA Crosstabs Function for Illustrating Time Series of Natural, Physical, and Human Capital.*Note: Efficacy codes of 'negative' and 'positive' are not included.

However, when applying the crosstabs function in MAXQDA, in comparing time series (x) to the efficacy dimensions of human capital reveals somewhat conclusive results. There seems to be a strong upward trend of the code 'negative' over time and a strong downward trend 
for the code 'positive' over time. Assuming these codes represent the efficacy of the community would suggest a downward spiral of efficacy (Figure 39).

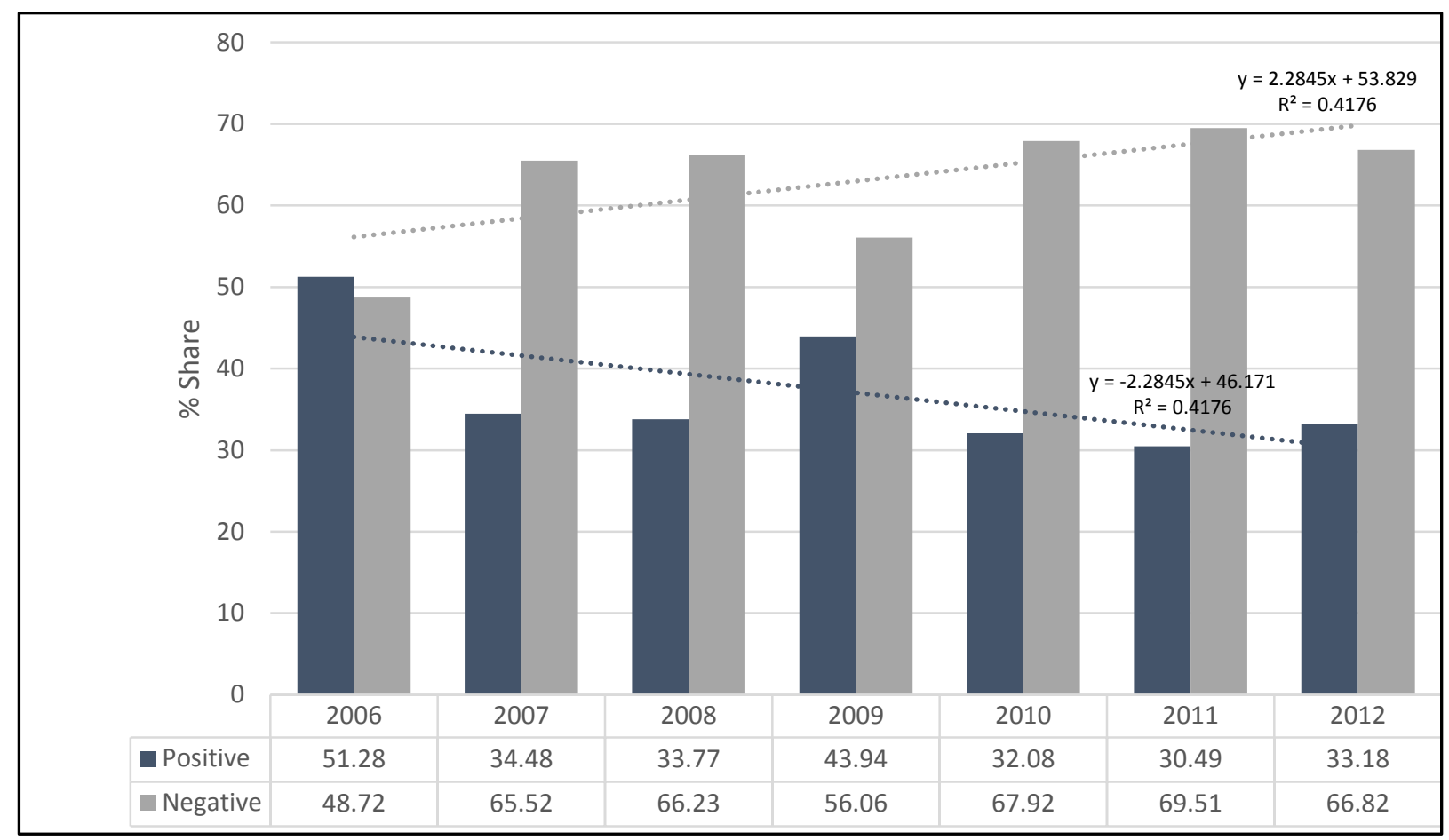

Figure 39. MAXQDA Crosstabs Function for Illustrating Time Series of Community Efficacy.

\section{Discussion}

The results in conducting this case study while simultaneously coding the city council minutes, seems to suggest Moundsville is not engaging in sustainable development strategies. First, and potentially most important, this study reveals the constructs of an energy systems model posited here, that although human capital under our definitions and coding structure is considered high, a social dimension of low community capital efficacy is revealed. Even though human capital may be high—if the effectiveness of the human capital is not engaged, then this hinders the ability for progress to be made towards a more sustainable and prosperous future.

This theory of efficacy is supported through early research by Linsley et al. (1995). If the ‘efficacy-performance spirals’ phenomenon is being observed at the individual, group, and organizational level; perhaps in the case of Moundsville, the community itself could be thought 
as a type of 'organization'. What the community of Moundsville is historically experiencing is a development pattern of boom and bust, or what one might call an up-spiral followed by a downspiral. Assuming we treat the community of Moundsville like an organization, one possible reason for existing in this wicked cycle may be due to the existing community having a low efficacy-performance which amplifies a bust. This situation is exacerbated by the failure to recognize the constructs leading to the bust. Until a community understands fully what leads to the boom and/or maintains sustainable development—only then may self-correcting measures be implemented, thus avoiding this continued boom and bust development pattern. It may also be important to point out a rival explanation to this theory could be that it is human nature to be quick to complain rather than give thanks or appreciation for something. To clarify, since much of this study is based on the city council minutes, the people that typically come to these meetings are those who are disgruntled or concerned about an issue; thus, this could skew the results.

In addition, the concept of 'boomtown' as defined by Gilmore’s (1976) and other researcher's definition of a communities’ population exceeding $15 \%$ annually does not seem to apply in the case of Moundsville. Although this may have been true for boomtowns in the past, this may not be valid today. This most likely is due to major technological advances and the increasing virtualization of the workforce. Furthermore, it should be noted the in-migration of transient workers are not integrated into these estimates and therefore may not capture the entire population.

Lending support to Tainter's concept of increasing complexity leading to collapse may be revealed to an extent in the case of Moundsville. As an example, this social phenomenon may explain why resource dependent economies tend to remain 'stuck' in this cycle of boom and 
bust. The historical culture of West Virginia is increasingly becoming more complex. As decisions are intertwined in money and politics, self-interests and or the human-will to solve problems may result in increasing investments that have decreasing payback for society as a whole. With time and money being diverted for purposes of maintaining non-renewable sources of energy as a staple for the West Virginia economy, reveals a wicked trade-off of short-term gains for long-term negative consequences. By not effectively investing into the more reproducible form of human capital and instead diverting resources to less sustainable development patterns will most likely result in a boom and bust cycle.

In exploring, Freudenberg’s (1992) theory of 'overadapting' in which industry takes over a local economy, it becomes more evident why a community may remain in this cycle of boom and bust. Currently, the county is experiencing a vast expansion of infrastructure dedicated specifically for the energy sector. By overadapting and allowing industry to effectively take over leaves community stakeholders stuck in a system built primarily for unsustainable extraction of finite resources.

Recognizing the wicked problems that are occurring in this community reminds us that such problems are not solvable, but instead can only be improved. As cited in Banathy (1996), Rittel and Webber state, "Solutions to design problems are good or bad. They are not true or false. Judgments of 'goodness of fit' of the solution may vary depending on people's interest, values, and perspectives” (p. 31). In the case of Moundsville, it seems this is particularly true that essentially this region of the country is informed by a values system based on an 'energy culture'. 


\section{Recent Developments}

As this case study has evolved, there have been a number of notable headlines that have occurred after the observations of the most critical time period of 2006-2012. The following is a brief description of each:

1. February, 2015 - Ohio and Marshall County mineral owners sign for \$100 million in Marcellus Shale lease agreements with Texas based driller Tug Hill with price per acre as much as $\$ 8,000$ with $20 \%$ royalties, but as low as $\$ 5 /$ acre with only $12.5 \%$ royalties.

2. February, 2015 - Gastar is one of several companies bidding with the West Virginia Department of Commerce (a potential \$40 million deal for West Virginia) to extract oil and natural gas from state-owned land below the Ohio River (calling it River Fracking) bordering Marshall County, but concerned citizens say it's not worth the environmental risks.

3. October, 2014 - Trans Energy to pay \$3.6 million in penalties for violating the Clean Water Act by impounding three Marshall County streams for building frack ponds.

4. August, 2014 - Marshall County will take ownership of a natural gas plant in the sum of $\$ 1$. This was approved by county commissioners as a 'Payment In Lieu of Tax' to facilitate the construction of the \$615 million 549 MW Moundsville Power gas electricity generator. However, some are concerned the $\$ 31$ million worth of lease payments over 30 years is inadequate for the county.

5. August, 2014 - Noble Energy Inc. funds a student dropout prevention program called “Energizing Our Youth”. Noble Energy Inc. provided \$300,000 over three years in partnership with Marshall County Schools and the Marshall County Chamber of Commerce for exploring careers in the energy field.

6. July, 2014 - Marshall County chooses to install additional water lines and perform maintenance work on the county courthouse with \$2.94 million worth of coal severance cash.

7. February, 2014 - An 8-ft sinkhole developed after a sanitary collection line collapsed on Jefferson Avenue resulting from the transportation of heavy equipment for supplying natural gas industry sites with well pads, compressor stations, and piping.

8. April, 2014 - Gas pipeline ruptures causing a huge fireball near Moundsville prompting concerned residents to consider moving away from Moundsville. 
9. March, 2014 - Permits for companies hosting sites with 10 or more people must apply for a labor camp permit.

10. March, 2014 - Oil and gas severance tax revenues jump more than $\$ 358,000$ during the past 3 years. $\$ 0$ will be used on local roads, but instead on state roads.

11. February, 2014 - Due to the 2011 Bill passed by the West Virginia legislature, a plant that was built in Marshall County only has to pay 5\% of $\$ 900$ million gas plant that was built, effectively losing 10 million in tax revenue and even more for years to come.

12. June, 2013 - A Tulsa, Oklahoma based company, Williams, plans on investing $\$ 4.5$ billion to process gas in Marshall County. The company processes gas for Chesapeake Energy, Gastar, Chevron, Stone Energy, Noble Energy and Trans Energy. Once complete, the company claims it will be able to process 2.5 billion cubic feet of natural gas per day and will employ approximately 250 permanent workers. (Retrieved from http://www.shaleplayohiovalley.com)

Another major development that should be noted is the passing of the 2014 Moundsville Comprehensive Plan. This process began with enlisting the services of the West Virginia University Public Administration faculty and students, and the Community Design Team (CDT) in 2011. This seems to be a major step forward for bringing community stakeholders together and "unlocking their community’s future”. However, although one of their goals in this plan is to "Properly plan for the natural gas industry," when it came to implementing this goal—it was ranked as a "low” priority (see Table 13). Ranking this action as a low priority potentially represents a disconnect between local stakeholders and properly planning for a more positive post-resource outcome. However, it may also reveal local stakeholders feel they do not have the voice, time, resources, or support for ranking this as a high priority. 


\section{Table 13}

Implementation Matrix for "Goal 5-Properly Plan for the Natural Gas Industry”

\begin{tabular}{|c|c|c|c|c|c|}
\hline Recommendation & Priority & $\begin{array}{l}\text { Responsible } \\
\text { Party }\end{array}$ & $\begin{array}{l}\text { Potential } \\
\text { Partners }\end{array}$ & $\begin{array}{l}\text { Estimated } \\
\text { Costs }\end{array}$ & $\begin{array}{l}\text { Funding } \\
\text { Sources }\end{array}$ \\
\hline $\begin{array}{l}\text { Help facilitate long-term local } \\
\text { employment opportunities in } \\
\text { the natural gas industry }\end{array}$ & Low & $\begin{array}{c}\text { City of } \\
\text { Moundsville }\end{array}$ & $\begin{array}{l}\text { Natural Gas } \\
\text { Companies }\end{array}$ & Staff Time & NA \\
\hline $\begin{array}{l}\text { Work with local school } \\
\text { officials to develop technical } \\
\text { and trade education } \\
\text { opportunities }\end{array}$ & Low & $\begin{array}{c}\text { City of } \\
\text { Moundsville }\end{array}$ & $\begin{array}{l}\text { Marshall County } \\
\text { Board of } \\
\text { Education/Trade } \\
\text { Schools }\end{array}$ & Staff Time & NA \\
\hline $\begin{array}{l}\text { Be proactive in identifying } \\
\text { whether the city can provide } \\
\text { all essential services to } \\
\text { persons living in trailer } \\
\text { camps }\end{array}$ & Low & $\begin{array}{c}\text { City of } \\
\text { Moundsville }\end{array}$ & NA & Staff Time & NA \\
\hline $\begin{array}{l}\text { Properly plan the placement } \\
\text { and development of trailer } \\
\text { camps }\end{array}$ & Low & $\begin{array}{c}\text { City of } \\
\text { Moundsville }\end{array}$ & $\begin{array}{l}\text { WVU Land Use } \\
\text { and Sustainable } \\
\text { Development } \\
\text { Law Clinic }\end{array}$ & $\begin{array}{l}\text { Staff time in } \\
\text { preparing } \\
\text { land use } \\
\text { ordinances }\end{array}$ & NA \\
\hline
\end{tabular}

Adapted from the City of Moundsville Comprehensive Plan, July, 2014, p. 5. 


\section{Chapter V}

\section{Conclusions}

The following is a concise overview for the Case of Moundsville beginning with summarizing the framework and methods used for analyzing the on-going theory. Then, major findings are presented including those of expected results and those that were seemingly counterintuitive. Finally, a discussion is needed for the limitations of this study and potential recommendations for improving the framework and moving theory into action for communities experiencing the cyclical development pattern of boom and bust.

\section{Summary}

The Energy Rich Region (ERR) of West Virginia exhibits a diverse and extensive prior pattern of boom and bust in timber, coal, oil, and natural gas. This region is blessed with ubiquitous amounts of natural wealth, however, people have remained comparatively more poor than other regions who lack natural wealth. The theory presents a path towards a more sustainable energy system. If total stock is maintained while converting natural capital to the more reproducible forms of human and physical capital, then we may assume the region is on a more sustainable path and therefore avoid the reoccurring cycle of boom and bust. The framework presented explores one such community, Moundsville, within an ERR which may assist future research dedicated to similar cases located in other Energy Rich Regions—allowing for multiple case comparisons. The framework presents an instrument known as the ERR Template which contains potential indicators for exploring sustainability through the inclusive wealth forms of natural, physical, and human capital. The template informs the primary methods utilized (1) Secondary data sources, 2) MAXQDA Open Coding, and 3) Participant Observation) including the open coding process of seven years of city council minutes with the assistance of 
MAXQDA. The data and information from these methods are then added to the Moundsville Knowledge Base for analysis.

The results reveal the wicked human problems that exist hinder the transition towards a more sustainable and diverse society. Furthermore, a dimension of poor community efficacy is revealed which may be a contributing factor to the inability to transform the natural capital into the more reproducible capital forms of human and physical capital. Unless human-will intervenes at the local level and commits to a more sustainable energy systems model, the development pattern of boom and bust will continue.

\section{Major Findings}

The overarching question of whether the natural capital (natural gas) is being converted effectively to the reproducible forms of human and physical capitals to avoid the reoccurring boom and bust cycles of the past is still unclear. Currently, ubiquitous amounts of natural gas is being produced in Marshall County, among several other resources including shale oil and coal. What this case study reveals is there are several 'wicked problems' relating to the boom in natural gas.

(1) Although there are vast sums of investment in the exploration, leasing, and infrastructure from the boom and natural gas — it seems these investments do not affect everyone equally. Primarily landowners (could be households, the State, University, or out-of-state Corporations) that have both mineral and surface rights with lots of land will be the winners, but only as long as these wells are producing which is dependent on the price of natural gas. Furthermore, the natural capital (natural gas) does not coincide with municipal boundaries and therefore limits the potential gain for such rural communities. 
(2) The enormous amounts of physical capital being put in place suggests corporate investors, Marshall County, and West Virginia are betting this boom is here for the foreseeable future. However, it seems most investments are moving towards energy specific infrastructure and not necessarily the built community environment, such as homes, buildings, schools, and local roads.

(3) What may be of most significance, is the development pattern of human capital and the additional social dimension of community's efficacy. Although there is a surge in natural capital, the human capital is decreasing in the community and county alike. Population — is continuing to decline (although this is slowing). The ability for the community to attract and keep the most educated for building a diverse and skilled workforce seems to also be a significant issue. Furthermore, by combining some of these descriptive statistics and coding seven years of city council minutes, seems to suggest a decline in community efficacy.

Revealing the multiple dimensions/layers occurring simultaneously may provide citizens and policymakers a more integrated/holistic approach to policy design. Additionally, the case of Moundsville, may promote a new framework for analyzing a community’s sustainability through the inclusive wealth forms of natural, physical, and human capital. The research implications reveal the need for a sustainable development programming guide for informing local and state stakeholders in transcending a model of boom and bust towards a more sustainable model of diversity.

\section{Limitations}

Yin (2003) states, “A previously developed theory is used as a template with which to compare the empirical results of the case study”. If two or more cases are shown to support the 
same theory, replication may be claimed. Currently, this is one case with potential future research dedicated to similar cases at the community level. Until the framework/approach employed here is conducted again, this limits the extent in which a community can be accurately compared to a similar community because such research using the approach seen here does not exist. However, for time and tractability purposes, the researcher for the case study of Moundsville assumes there are similar phenomena occurring throughout communities in West Virginia; thus informing a regional development pattern of boom and bust.

"Validity, in qualitative methods hinges to a great extent on the skill, competence, and rigor of the evaluator because the observer is the instrument” (Patton, 1987). Keeping this in mind, I am not perfect, however steps were taken to make this case more systematic and unbiased. Efforts were made including those of reflexivity, using multiple methods for comparing results (triangulation), the use of the software program MAXQDA which allows the researcher to inductively explore the data itself (grounded theory), testing the ERR template in a classroom setting with the assistance of expert knowledge and feedback, and finally as recommended by Yin (2003) a protocol was created via the "Moundsville Knowledge Base” which allows a researcher thoroughly process the many stages in conducting a case study and creates a more systematic case. However, even with these techniques in maintaining errors, open social systems are extremely complex and therefore imperfections are likely.

Finally, other limitations include data quality and time. Data was retrieved where possible, however in some cases there were incomplete data sets, and data was retrieved from different sources for gathering specific dates, or in some cases no data existed. Time was a limiting factor too. The use of the qualitative data software program MAXQDA was self-taught 
and therefore limits the preferred methods for analysis or capabilities to explore deeper into integrating this software with programs like SPSS.

\section{Future Research}

Further research could involve the framework presented here, however a future framework could be improved by providing additional quantitative results behind the qualitative results. The program MAXQDA has the ability to interface with statistical programs such as SPSS which may provide improved statistical results by using a correlation and or a simple regression model.

Typically programming is seen to apply only to architectural and or design projects for specific clients. However, programming could be appropriate for thoroughly understanding the problem and needs for a particular community to better inform the decision-making process.

This programming process could be utilized for smaller historically resource dependent communities strategizing on approaches for transforming their boom and bust development patterns towards a more sustainable development pattern. However, for such a process to successfully assist a community—-the community must first recognize and engage the humanwill to change through an iterative decision making process. Furthermore, there seems to be a 'sit and wait until something happens' mentality. A strategic energy planning process would assist a community in dealing with the latest boom in natural gas. By the time leases are signed and campers are moving in — this is too late, and can result in rushed and negligent decision making by all stakeholders. Of course, this cannot all be projected from the inaction of one community. This community is already overwhelmed by the normal day to day decision-making and lack the time and appropriate resources. At times there seems to be a lack of empowering local decision making. This is partially because the decision making process (especially as it applies to oil and 
gas) is a state decision, thus limiting the power a local community has over its resources. And then there is the issue of severance taxes. This wealth first goes to the state and then is distributed to the county level. However, the county has a ruling in how this money is dispersed to the local communities. This seems to be a rather complex, redundant, and ineffective system and should be re-evaluated.

In addition, it may be advantageous to explore the idea of having a federal or state agency program that provides assistance for natural resource dependent communities. As an example, given the lack of time and resources at the local government level, there may be a role for the USDA or perhaps the state extension office to provide guidance in sustainable development strategies by holding stakeholder meetings and or providing education resources.

In recognizing these additional constructs and processes of this energy system should assist in the development of a programming guide. To reiterate, a general guide to sustainable community development was suggested by the President's Council of Sustainable Development. Perhaps before a community programming guide is developed, the following principles may be advantageous for informing this programming guide:

(1) All people have access to educational opportunities that prepare them for jobs to support themselves and their families in a dynamic local economy that is prepared to cope with changes in the national and global economy.

(2) People are involved in making decisions that affect their lives.

(3) Businesses, households, and government make efficient use of land, energy, and other resources, allowing the area to achieve a high quality of life with minimal waste and environmental damage.

(4) These communities are healthy and secure, and provide people with clean air to breathe and safe water to drink. (PCSD, May, 1999)

The findings and implications in conducting the case of Moundsville could be significant not only at the community level, but internationally. The IEA states, "Taking all new development and policies into account, the world is still failing to put the global energy system 
onto a more sustainable path (2012).” In addition, the IEA claims a cumulative investment of \$37 trillion is needed worldwide to meet the energy demands through 2012-2035 (2012). Placing this into perspective, real change through human-will can begin at the community level bringing new insight to the commonly quoted expression "think globally and lead locally". This can effectively transform these wicked problems into actions of progress, thus changing the landscape of a region for a more sustainable and prosperous future. 


\section{References}

Ades, A., \& Rafael, D. (1999). Rents, competition, and corruption. American economic review. 894, 982-993.

Allenby, B. R. (1998). Industrial Ecology: Policy Framework and Implementation. Upper Saddle River, NJ: Prentice-Hall.

Arif, H. (2012). Is West Virginia Missing Out on the Creative Economy? Martin Prosperity Insights, Retrieved 11/16/2012. Retrieved from http://martinprosperity.org/2012/11/16/insight-is-west-virginia-missing-out-on-thecreative-economy/

Ary, D., Jacobs, L. C., \& Sorensen, C. (2010). Introduction to Research in Education (8th Ed.). Belmont, CA: Wadsworth, Cengage Learning.

Auty, R. M. (1993). Sustaining development in mineral economies: the resource curse thesis. New York, NY, Routledge.

Bailey, R. (2001). Post-Scarcity Prophet. Reason Magazine. Retrieved 12/16/12, from http://reason.com/archives/2001/12/01/post-scarcity-prophet.

Banathy, B. H. (1996). Designing Social Systems in a Changing World. New York, N.Y.: Plenum Press.

Bosselman, F., Eisen, J. B., Rossi, J., Spence, D. B., \& Weaver, J. (2010). Energy, Economics, and the Environment: Cases and Materials. New York: Thomas Reuters/Foundation Press.

Boyd, Peter (1927). History of Northern West Virginia Pan Handle: Embracing Ohio, Marshall, Brooke, and Hancock counties. Indianapolis, IN: Historical Publishing Company.

Braungart, M. \& McDonough, W. (2002). Cradle to cradle: Remaking the way we make things. New York: North Point Press.

Braungart, M., \& McDonough, W. (2013). The Upcycle: Beyond sustainability--designing for abundance. New York City: Charles Melcher.

Casto, J. E. (2004). Southern West Virginia Coal Country. Chicago, IL: Arcadia Publishing.

Calthorpe, P. (2011). Urbanism in the age of climate change. Washington, DC: Island Press.

City of Moundsville Comprehensive Plan (Adopted July 2014). Retrieved from http://www.cityofmoundsville.com/comp_plan_2014.pdf.

Clemins, J. D. (2010). West Virginia Penitentiary: Arcadia Publishing. 
Clark, C. W. (1991). Economic biases against sustainable development. In R. Costanza (Ed.), Ecological economics: The Science and management of sustainability. New York, NY, Columbia University Press.

Community Design Team (CDT). (2013). Retrieved from http://communitydesign.wvu.edu/what_we_do.

Chen, X., Orum, A. M., \& Paulsen, K. E. (2013). Introduction to Cities: How Place and Space Shape Human Experience: Wiley-Blackwell.

Cherry, E. (1999). Programming for design: From theory to practice. John Wiley \& Sons Inc.

Court, C. D., Jackson, R., \& White, N. E. (2012). The role of regional science in shale energy development. The Review of Regional Studies, 42, 99-105.

Creswell, J. W. (2003). Research design: Qualitative, quantitative, and mixed method approaches. Thousand Oaks, Calif.: Sage Publications.

Dickinson, J. I., \& Marsden, J. P. (2009). Informing Design: Bloomsbury Academic.

Editorial. (2012). Develop plans for life after coal, The Charleston Gazette.

Emery, M., \& Flora, C. (2006). Spiraling-up: Mapping community transformation with community capitals framework. Community Development, 37(1), 19-35.

Environmental Protection Agency (Feb. 2015). The hydraulic fracturing water cycle. Retrieved from http://www2.epa.gov/hfstudy/hydraulic-fracturing-water-cycle.

Flora, C., \& Flora, J. (2008). 5th Annual community capitals framework institute, Retrieved 10/24/2013, 2013. Retrieved from http://www.soc.iastate.edu/staff/cflora/ncrcrd/capitals.html.

Glaser, B.G., \& Strauss, A.L. (1967). The discovery of grounded theory: Strategies for qualitative research. Chicago: Aldine Transaction.

Florida, R. (2011). The creative class paradigm. In D.E. Anderson, C. Mellander, \& E. Elgar (Eds.), Handbook of creative cities (pp. 56-71).

Freudenburg, W. R. (1981). Women and Men in an Energy Boomtown: Adjustment, Alienation and Adaptation. Rural Sociology, 46(2), 220-244.

Ghadimi, H. (2010). Sustainable economic development in energy rich economies: A regional approach. Paper presented at the Western Regional Science Association: 49th Annual Cosmic Convergence, Sedona, Arizona. 
Ghadimi, H., Harris, T. M., \& Warner, T. A. (2014). Measuring the wealth of regions: Geospatial approaches to empirical capital estimation. In J. L. Pender, B. A. Weber, T. G. Johnson \& M. J. Fannin (Eds.), Rural Wealth Creation (pp. 328): Routledge.

Gilmore, J. S. (1976). Boom Towns May Hinder Energy Resource Development. Science, 191(4227), 535-540. doi: 10.2307/1741302.

Gowdy, J. (1999). Economic concepts of sustainability: Relocating economic activity within society and environment. In E. Becker \& T. Jahn (Eds.), Sustainability and the social sciences: A Cross-disciplinary approach to integrating environmental considerations into theoretical reorientation. London: Zed Books Ltd.

Gylfason, T., Herbertsson, T.T., Zoega, G. (1999). A mixed blessing: Natural resources and economic growth. Macroeconomic Dynamics, 3, 204-225.

Hanson, S. (March 20, 2014). Marshall County gas tax jumps by $\$ 358,000$. Shale Play. Retrieved from http://shaleplayohiovalley.com/page/content.detail/id/500839/MarshallCounty-Gas-Tax-Jumps-by--358-000.html?nav=5020.

Hardin, G. (1968). The tragedy of the commons. Science, 162, 1243-1248.

ICLEI (2013). Retrieved from http://www.icleiusa.org/about-iclei/how-iclei-can-help-your-localgovernment.

ICMA (2010). Putting Smart Growth to Work in Rural Communities. Retrieved from http://reconnectingamerica.org/assets/Uploads/2010_smartgrowthrural.pdf.

International Energy Agency (2012). World Energy Outlook 2012. London.

Jick, T. (1979). Mixing qualitative and quantitative methods: Triangulation in action. Administrative Science Quarterly, 24(4), 602-611.

Junkins, C. (2014, July 9).State withholding severance tax money. The Intelligencer Wheeling News-Register. Retrieved from http://www.theintelligencer.net/page/content.detail/id/606037/State-WithholdingSeverance-Tax-Money.html.

King H.B. (April, 2015). Marcellus Shale-Appalachian basin natural gas play: A resource that moved from "marginal" to "spectacular" as a result of new drilling technology. Retrieved from http://geology.com/articles/marcellus-shale.shtml.

Kinnaman, T. C. (2011). The economic impact of shale gas extraction: A review of existing studies. Ecological Economics, 70(7), 1243-1249.

Knox, P. L., \& Mayer, H. (2013). Small Town Sustainability: Economic, Social, and Environmental Innovation (Second Ed.). Basel, Switzerland: Birkhauser Verlag GmbH. 
Lincoln Y.S. \& Guba E.G. (1985). Naturalistic inquiry. Newbury Park, California: Sage Publications, Inc.

Lindsley, D.H, Brass, D.J., \& Thomas, J.B. (1995). Efficacy-performance spirals: A multilevel perspective. Academy of Management Review, 20(3), 645-678.

Mehlum, H., Moene, K., \& Torvik, R. (2006). Institutions and the resource curse. The Economic Journal, 116(508), 1-20.

Meredith, S. (2009). Beyond light bulbs: Lighting the way to smarter energy management. Austin, TX: Emerald Book Co.

Monolith Press (2012). U.N. Agenda 21: Sustainable Development in the U.S.A. (Vol. 2).

Paehlke, R. (1999). Towards defining, measuring and achieving sustainability: Tools and strategies for environmental valuation. In E. Becker \& T. Jahn (Eds.), Sustainability and the social science: A cross-disciplinary approach to integrating environmental considerations into theoretical reorientation. London: Zedd Books Ltd.

Patton, M. Q. (1987). How to use qualitative methods in evaluation: Sage Publications.

Peña, W., Focke, J. W. (1969). Problem seeking: New directions in architectural programming: Caudill Rowlett Scott.

PBS, Montana. (2012). Boom behind the Bakken. In E. Beechie \& E. Foster (Producers). The University of Montana.

Putnam, R. (2000). Bowling Alone: The Collapse and Revival of American Community. New York: Simon \& Schuster.

President's Council for Sustainable Development (1999). Towards a sustainable America: Advancing prosperity, opportunity, and a healthy environment for the 21st century.

Ritchey, T. (2013). Wicked problems: Modelling social messes with morphological analysis. Acta Morphologica Generalis, 2(1).

Rittel, H. \& Webber, M. (1973). Dilemmas in a general theory of planning. Policy Sciences, 4, 155-169.

Rocky Mountain Institute (1998). Green development: Integrating ecology and real estate. John Wiley \& Sons Inc.

Sachs, I. (1999). Social sustainability and whole development: Exploring the dimensions of sustainable development. In E. Becker \& T. Jahn (Eds.), Sustainability and the social sciences: A cross-disciplinary approach to integrating environmental considerations into theoretical reorientation. London: Zed Books Ltd. 
Sachs, J., \& Warner, A. M. (1995). Natural resource abundance and economic growth. Cambridge, MA: National Bureau of Economic Research.

Sachs, J. D., \& Rodriguez, F. (1999). Why do resource-abundant economies grow more slowly? Journal of Economic Growth, 4, 277-303.

Sachs, J. D., \& Warner, A. M. (2001). The curse of natural resources. European Economic Review, 45(4-6), 827-838.

Shaleplayohiovalley.com (2015). Retrieved articles from http://www.shaleplayohiovalley.com/page/category.detail/nav/5020/MarshallCounty.htm).

Schramm, R. W. (2004). Images of America: Moundsville: Arcadia Publishing.

Solow, R. M. (1956). A Contribution to the theory of economic growth. The Quarterly Journal of Economics, 70(1), 65-94.

Solow, R. M. (2005). Sustainability: An economist's perspective. In R. N. Stavins (Ed.), Economics of the Environment (5th Ed.). New York: W. W. Norton \& Company.

Stiglitz, J., Sen, A., \& Fitoussi, J. (2008). The measurement of economic performance and social progress revisited. Retrieved from http://www.stiglitz-senfitoussi.fr/documents/overview-eng.pdf.

Tainter, J. A. (1988). The Collapse of complex societies. Cambridge, UK: Cambridge University Press.

The Associated Press (June 10, 2013). Former glass plant site ready for redevelopment, Charleston Gazette.

The President's Council for Sustainable Development (PCSD) (May, 1999). Towards a sustainable America: Advancing prosperity, opportunity, and a healthy environment for the $21^{\text {st }}$ century. Retrieved from http://clinton4.nara.gov/media/pdf/tsa.pdf.

The State Journal (Feb. 23, 2013). Marshall County assessed property values double in six years. Retrieved from http://www.statejournal.com/story/20672694/marshall-county-assessedproperty-values-double-in-six-years.

U.S. Census (2013). Geography. Retrieved from http://www.census.gov/geo/reference/gtc/gtc_urbanrural.html.

U.S. Energy Information Administration (2012). What is shale gas and why is it important? Energy in Brief. Retrieved 06/30, 2014, from www.eia.gov/energy_in_brief/article/about_shale_gas.cfm. 
U.S. Energy Information Administration (Dec. 9, 2013). Marcellus region to provide 18\% of total U.S. natural gas production this month. Washington D.C.: U.S. Department of Energy. Retrieved from http://www.eia.gov/todayinenergy/detail.cfm?id=14091\#.

U.S. Energy Information Administration (2013). Technically recoverable shale oil and shale gas resources: An assessment of 137 shale formations in 41 countries outside the United States. Washington D.C.: U.S. Department of Energy.

U.S. Geological Survey. Man-Made Earthquakes Update. (2011). Science Features, 2014, from http://www.usgs.gov/blogs/features/usgs_top_story/man-made-earthquakes/.

U.S. Office of Management and Budget (2013). Retrieved from http://www.census.gov/population/metro/.

Waples, D. A. (2005). The natural gas industry in Appalachia. Jefferson, NC: McFarland \& Company, Inc.

West Virginia Center for Budget and Policy (Feb. 2012). Estimating the future fund. Retrieved from http://www.wvpolicy.org/estimating-the-future-fund.

West Virginia Center for Budget and Policy (April, 2014). Impacts of drilling in Wetzel County. Retrieved from http://www.wvpolicy.org/wp-content/uploads/2014/04/Impacts-ofDrilling-in-Wetzel-County.pdf.

West Virginia Department of Environmental Protection. (2011). State of the Environment Report $4^{\text {th }}$ edition. Retrieved from http://www.dep.wv.gov/news/Documents/SOTE\%202011\%20web.pdf

West Virginia Geologic and Economic Survey. Retrieved from http://www.wvgs.wvnet.edu/www/index.html.

Weinstein, A., \& Partridge, M. D. (2011). The economic value of shale natural gas in Ohio. Swank program in rural-urban policy summary and report. The Ohio State University, Columbus, Ohio.

White, Nancy E. (2012). A Tale of Two Shale Plays. The Review of Regional Studies, 42, 107119.

Winkler, R., Cheng, C., \& Golding, S. (2011). Boom or bust? Population dynamics in natural resource-dependent counties. International Handbook of Rural Demography, 3, 349-367. London: Springer.

World Commission on Environment and Development. (1987). Our common future. Oxford; New York: Oxford University Press. 
Yin, R. K. (2003). Case study research: Design and methods (3rd Ed.). Thousand Oaks: Sage Publications, Inc. 


\section{Appendices}

\section{Appendix A: Energy Rich Region (ERR) Template.}

\begin{tabular}{|c|c|c|c|c|c|}
\hline \\
\hline Population Composition \& Key Figures & Region Value & $\begin{array}{l}\text { Compare to } \\
\text { State Rank }\end{array}$ & \begin{tabular}{|c|}
$\begin{array}{c}\text { Compare to US } \\
\text { Rank }\end{array}$ \\
\end{tabular} & Source/Link & Additional Source/Link \\
\hline Total Population (2012) & & & & STATS America & \\
\hline Growth \% since 1980-2010 & & & & STATS America & \\
\hline Median Age & & & & STATS America & \\
\hline Total Population 25 and Older & & & & STATS America & \\
\hline Total \% Receiving a High School Diploma or More & & & & STATS America & \\
\hline Total \% Completing a Bachelors Degree or More & & & & STATS America & \\
\hline Average Household Size & & & & STATS America & \\
\hline Average Family Household Size & & & & STATS America & \\
\hline Unemployment Rate \% (Dec, 2012) & & & & STATS America & \\
\hline Median Income (2011) in 2011 Dollars & & & & STATS America & \\
\hline Median Household Income (2011) in 2011 Dollars & & & & STATS America & \\
\hline Per Capita Personal Income (2011) & & & & STATS America & \\
\hline Poverty Rate for all ages \% (2011) & & & & STATS America & \\
\hline Cost of Living \% (US=100) & & & & Moody's Précis State & Moody's Précis Metro \\
\hline Net Domestic Migration (chg. 2010/2011) & & & & STATS America & \\
\hline Net International Migration (chg. 2010/2011) & & & & STATS America & \\
\hline Well-Being Index Score (2012) & & & & $\begin{array}{l}\text { Gallup-Healthways Well- } \\
\text { Being Index } \\
\end{array}$ & \\
\hline \multicolumn{6}{|l|}{ Environment } \\
\hline Land Cover (square miles) & Region Value & $\%$ Total Area & & & \\
\hline \begin{tabular}{|l} 
Land Area \\
\end{tabular} & & & & USGS Land Cover Viewer & \\
\hline Forest \& Woodland & & & & USGS Land Cover Viewer & \\
\hline Agricultural Vegetation & & & & USGS Land Cover Viewer & \\
\hline Developed \& Other Human Use & & & & USGS Land Cover Viewer & \\
\hline Open Water & & & & USGS Land Cover Viewer & \\
\hline Other & & & & USGS Land Cover Viewer & \\
\hline Energy Figures & Region Value & & $\begin{array}{l}\text { Compare to } \\
\text { Rank in US } \\
\end{array}$ & & \\
\hline Total Energy Production (trillion BTU) & & & & U.S. EIA & \\
\hline Total Energy Consumed per Capita, 2010 (million BTU) & & & & U.S. EIA & \\
\hline Energy Consumption per Real Dollar of GDP (Thousand & & & & U.S. EIA & \\
\hline BTU/chained 2005 dollars) & & & & & \\
\hline CO2 emissions 2011 (metric tons) from Electric Power & & & & U.S. EIA & \\
\hline
\end{tabular}




\begin{tabular}{|c|c|c|}
\hline \multicolumn{3}{|l|}{ Total Assets (Wealth) } \\
\hline Evaluation Area & Values & Source/Link \\
\hline \multicolumn{3}{|l|}{ Physical Capital } \\
\hline \multicolumn{3}{|l|}{ Buildings } \\
\hline \begin{tabular}{|l|} 
Buildings (Residential) \\
\end{tabular} & & 2010 Census \\
\hline Buildings (Non-Residential) & & Hospitals Government, Commercial, etc. \\
\hline \multicolumn{3}{|l|}{ Land } \\
\hline \multirow{2}{*}{ Roads,Highways, Bridges } & & TAMU Urban Mobility Information \\
\hline & & US Dept. of Transportation RITA \\
\hline Rail Lines & & US Dept. of Transportation RITA \\
\hline Mass Transit Lines (buses, subways, light rail) & & US Dept. of Transportation RITA \\
\hline \multicolumn{3}{|l|}{\begin{tabular}{|c|} 
Waterways \\
\end{tabular}} \\
\hline \multirow{3}{*}{ Navigation Channels and Ports } & & Regional and state government \\
\hline & & US Dept. of Transportation RITA \\
\hline & & Port authorities \\
\hline \multicolumn{3}{|l|}{ Air } \\
\hline Air Routes and Airports & & US Dept. of Transportation RITA \\
\hline \multicolumn{3}{|l|}{\begin{tabular}{|r|} 
Pipelines \\
\end{tabular}} \\
\hline \multirow{2}{*}{ Pipelines } & & EIA - Natural Gas Pipeline Network \\
\hline & & American Petroleum Institute (API) \\
\hline \multicolumn{3}{|l|}{ Information and Electric Connectivity } \\
\hline Telecommunications & & The Information Technology \& Innovation Foundation (ITIF) \\
\hline Electric Grid, Transmission \& Distribution & & Federal Energy Regulatory Commission (FERC) \\
\hline
\end{tabular}




\begin{tabular}{|c|c|}
\hline \multicolumn{2}{|l|}{ Human Capital } \\
\hline Education & \\
\hline \multirow{4}{*}{ K-12 Education Systems } & National Assessment of Educational Progress (NAEP) Scores \\
\hline & College Board SAT/ACT Scores \\
\hline & ETS Graduation Rates \\
\hline & STATS America Educational Attainment \\
\hline Community Colleges and Technical Schools & Community College Trends and Statistics \\
\hline \multirow{3}{*}{ Four-Year Colleges and Universities } & US News and World Report Rankings \\
\hline & WebCASPAR US National Science Foundation (NSF) \\
\hline & $\begin{array}{l}\text { Almanac of Higher Education } 2012 \text { Chronicle of Higher } \\
\text { Education }\end{array}$ \\
\hline Workforce and Training Programs & U.S. Department of Labor Services By Location \\
\hline \multirow{2}{*}{ Workforce Availability/Occupational Analysis } & American FactFinder Community Facts Education \\
\hline & Bureau of Labor Statistics data \\
\hline \multicolumn{2}{|l|}{ Innovation \& Technology } \\
\hline High Tech Jobs & The Information Technology \& Innovation Foundation (ITIF) \\
\hline \multirow[t]{2}{*}{ Scientists and Engineers } & The Information Technology \& Innovation Foundation (ITIF) \\
\hline & Bureau of Labor Statistics data \\
\hline \multirow[b]{2}{*}{ Patents } & US Patent \& Trademark Office \\
\hline & The Information Technology \& Innovation Foundation (ITIF) \\
\hline \multirow[t]{2}{*}{ Industry Investment in R\&D } & The Information Technology \& Innovation Foundation (ITIF) \\
\hline & National Science Foundation R\&D \\
\hline \multirow[t]{2}{*}{ Non-Industry Investment in R\&D } & The Information Technology \& Innovation Foundation (ITIF) \\
\hline & National Science Foundation R\&D \\
\hline \multirow{4}{*}{ Movement towards a Green Economy } & The Information Technology \& Innovation Foundation (ITIF) \\
\hline & U.S. Energy Information Administration \\
\hline & DSIRE USA \\
\hline & BLS Green Technologies and Practices \\
\hline \multirow[t]{2}{*}{ Venture Capital } & The Information Technology \& Innovation Foundation (ITIF) \\
\hline & PWC MoneyTree \\
\hline
\end{tabular}




\begin{tabular}{|c|c|}
\hline \multicolumn{2}{|l|}{ Natural Capital } \\
\hline \multicolumn{2}{|l|}{ Energy-Finite Resources } \\
\hline Oil Proved Reserves & U.S. Energy Information Administration \\
\hline Natural Gas Proved Reserves & U.S. Energy Information Administration \\
\hline Coal Proved Reserves & U.S. Energy Information Administration \\
\hline \multicolumn{2}{|l|}{ Energy-Renewable Resources } \\
\hline Wind & U.S. Energy Information Administration \\
\hline Solar Photovoltaic \& Thermal & U.S. Energy Information Administration \\
\hline Hydro & U.S. Energy Information Administration \\
\hline Biomass & U.S. Energy Information Administration \\
\hline Geothermal & U.S. Energy Information Administration \\
\hline \multicolumn{2}{|l|}{ Energy-Other } \\
\hline Nuclear & U.S. Energy Information Administration \\
\hline \multicolumn{2}{|l|}{ Mineral Resources } \\
\hline $\begin{array}{l}\text { bauxite, copper, gold, silver, iron, lead, nickel, } \\
\text { phosphate, tin, zinc, rare earth elements, limestone, } \\
\text { uranium }\end{array}$ & USGS Mineral Resources Data System \\
\hline \multicolumn{2}{|l|}{ Other } \\
\hline \multirow{3}{*}{ Timber Resources } & World Bank Changing Wealth of Nations \\
\hline & US Forest Service Research \\
\hline & USGS Land Cover Viewer \\
\hline \multirow{3}{*}{ Nontimber Forest Resources } & World Bank Changing Wealth of Nations \\
\hline & USGS Land Cover Viewer \\
\hline & US Forest Service Research \\
\hline \multirow{3}{*}{ Cropland } & World Bank Changing Wealth of Nations \\
\hline & USGS Land Cover Viewer \\
\hline & USDA AG Census \\
\hline \multirow{3}{*}{ Pastureland } & World Bank Changing Wealth of Nations \\
\hline & USGS Land Cover Viewer \\
\hline & USDA AG Census \\
\hline \multirow{6}{*}{ Protected Areas } & World Bank Changing Wealth of Nations \\
\hline & USGS Land Cover Viewer \\
\hline & National Conservation Easement Database \\
\hline & National Marine Protected Areas Center \\
\hline & National Park Service \\
\hline & US Fish and Wildlife Service \\
\hline
\end{tabular}




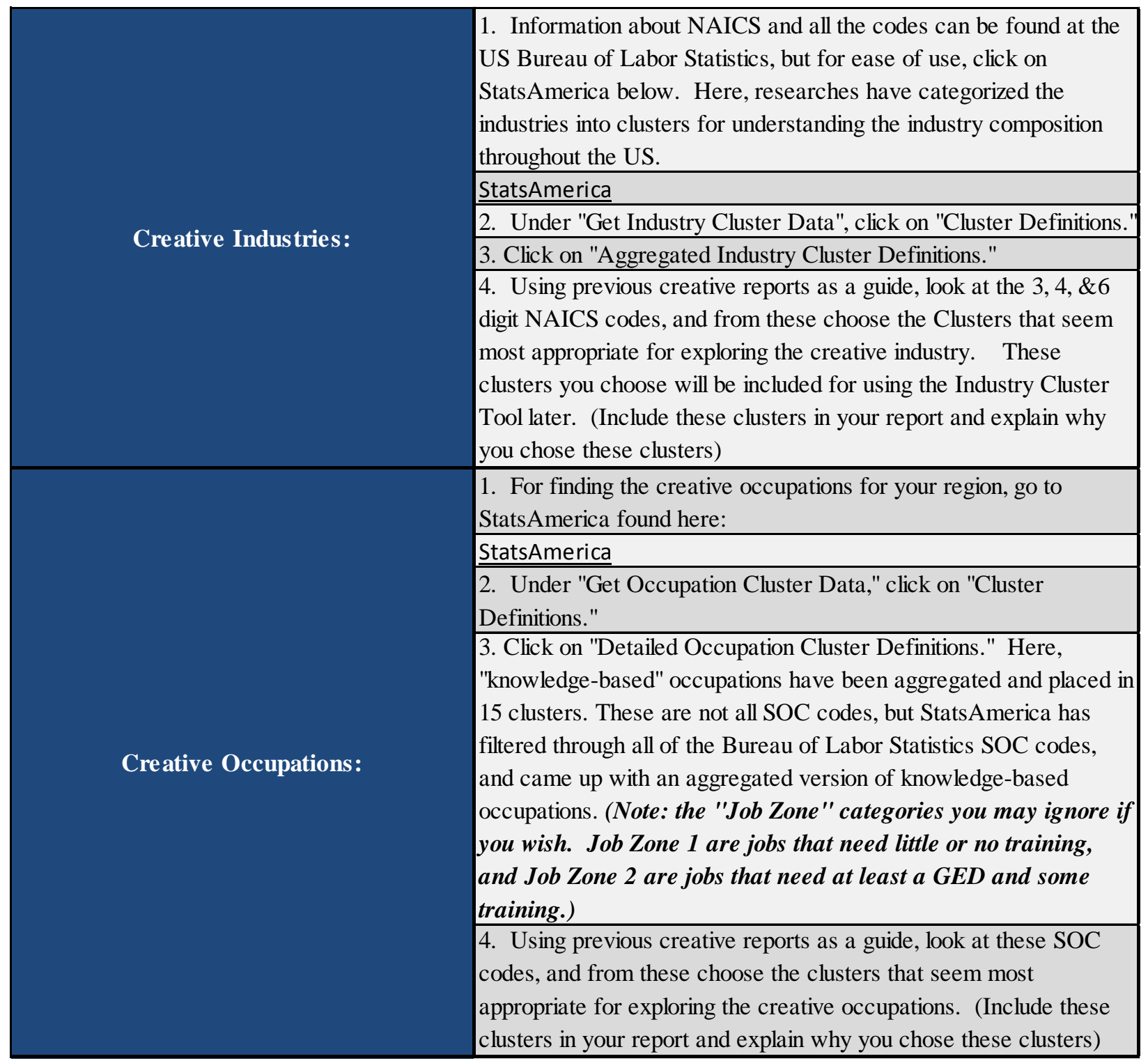


Appendix B: MAXQDA Open Coding System with Frequencies and Number of Documents.

\begin{tabular}{|c|c|c|c|}
\hline Parent code & Code & $\begin{array}{c}\text { Activated } \\
\text { coded } \\
\text { segments \% }\end{array}$ & Documents \\
\hline Human Capital & & 0.07 & 6 \\
\hline Human Capital & Regional & 0.12 & 13 \\
\hline Human Capital & Town & 0.24 & 23 \\
\hline Human Capital & County & 0.45 & 37 \\
\hline Human Capital & Federal & 0.53 & 37 \\
\hline Human Capital & State & 1.00 & 71 \\
\hline Human Capital & Positive & 4.37 & 127 \\
\hline Human Capital & Negative & 7.75 & 132 \\
\hline Human Capital/County & Marshall County Fair Board & 0.10 & 10 \\
\hline Human Capital/County & Marshall County Board of Education & 0.17 & 14 \\
\hline Human Capital/County & Marshall County Commission & 0.27 & 25 \\
\hline Human Capital/County & $\begin{array}{l}\text { Marshall County Chamber of } \\
\text { Commerce }\end{array}$ & 0.43 & 36 \\
\hline Human Capital $\backslash$ State & Extension Service & 0.02 & 2 \\
\hline Human Capital\State & DEP & 0.36 & 33 \\
\hline Human Capital\State & Department of Highway & 0.52 & 44 \\
\hline Human Capital\Town & Population & 0.02 & 5 \\
\hline Human Capital\Town & Economic Development & 0.07 & 8 \\
\hline Human Capital\Town & Education & 0.11 & 12 \\
\hline Human Capital\Town & Tourism and Recreation & 0.17 & 18 \\
\hline Human Capital\Town & Transportation & 0.21 & 22 \\
\hline Human Capital\Town & University & 0.22 & 17 \\
\hline Human Capital\Town & Non Profits and Organizations & 0.28 & 24 \\
\hline Human Capital\Town & Crime and Death & 0.36 & 24 \\
\hline Human Capital\Town & Beautification & 0.37 & 35 \\
\hline Human Capital\Town & Moundsville Daily Echo & 0.47 & 42 \\
\hline Human Capital\Town & Public Safety & 0.59 & 48 \\
\hline Human Capital\Town & Human Health and Environment & 0.65 & 42 \\
\hline Human Capital\Town & City Departments and Employees & 0.85 & 59 \\
\hline Human Capital\Town & Culture & 1.43 & 86 \\
\hline Human Capital\Town & Policy & 3.09 & 104 \\
\hline Human Capital\Town & Finances & 5.46 & 134 \\
\hline $\begin{array}{l}\text { Human Capital\Town } \backslash \text { City Departments and } \\
\text { Employees }\end{array}$ & Sanford Resource Center Board & 0.09 & 9 \\
\hline $\begin{array}{l}\text { Human Capital\Town\City Departments and } \\
\text { Employees }\end{array}$ & Attendance & 0.12 & 9 \\
\hline $\begin{array}{l}\text { Human Capital\Town } \backslash \text { City Departments and } \\
\text { Employees }\end{array}$ & Historic Landmarks Commission & 0.12 & 14 \\
\hline $\begin{array}{l}\text { Human Capital\Town \City Departments and } \\
\text { Employees }\end{array}$ & Petition & 0.12 & 11 \\
\hline $\begin{array}{l}\text { Human Capital\Town\City Departments and } \\
\text { Employees }\end{array}$ & Liability Insurance & 0.13 & 12 \\
\hline $\begin{array}{l}\text { Human Capital\Town\City Departments and } \\
\text { Employees }\end{array}$ & Moundsville Housing Authority & 0.14 & 15 \\
\hline
\end{tabular}




\begin{tabular}{|c|c|c|c|}
\hline $\begin{array}{l}\text { Human Capital\Town } \backslash \text { City Departments and } \\
\text { Employees }\end{array}$ & Zoning Board & 0.19 & 13 \\
\hline $\begin{array}{l}\text { Human Capital\Town } \backslash \text { City Departments and } \\
\text { Employees }\end{array}$ & Storm Water Department & 0.25 & 20 \\
\hline $\begin{array}{l}\text { Human Capital\Town } \backslash \text { City Departments and } \\
\text { Employees }\end{array}$ & Building Commission & 0.28 & 28 \\
\hline $\begin{array}{l}\text { Human Capital\Town } \backslash \text { City Departments and } \\
\text { Employees }\end{array}$ & Comprehensive Plan & 0.40 & 28 \\
\hline $\begin{array}{l}\text { Human Capital\Town } \backslash \text { City Departments and } \\
\text { Employees }\end{array}$ & Training & 0.41 & 32 \\
\hline $\begin{array}{l}\text { Human Capital\Town } \backslash \text { City Departments and } \\
\text { Employees }\end{array}$ & Executive Session & 0.42 & 31 \\
\hline $\begin{array}{l}\text { Human Capital\Town\City Departments and } \\
\text { Employees }\end{array}$ & Voting and Elections & 0.42 & 34 \\
\hline $\begin{array}{l}\text { Human Capital\Town } \backslash \text { City Departments and } \\
\text { Employees }\end{array}$ & Water Department & 0.56 & 43 \\
\hline $\begin{array}{l}\text { Human Capital\Town\City Departments and } \\
\text { Employees }\end{array}$ & Planning Commission & 0.60 & 43 \\
\hline $\begin{array}{l}\text { Human Capital\Town\City Departments and } \\
\text { Employees }\end{array}$ & Policy Committee & 0.74 & 58 \\
\hline $\begin{array}{l}\text { Human Capital\Town\City Departments and } \\
\text { Employees }\end{array}$ & $\begin{array}{l}\text { Council, Commission, Board } \\
\text { Turnover }\end{array}$ & 0.78 & 50 \\
\hline $\begin{array}{l}\text { Human Capital\Town } \backslash \text { City Departments and } \\
\text { Employees }\end{array}$ & Parks and Recreation Commission & 0.78 & 57 \\
\hline $\begin{array}{l}\text { Human Capital\Town } \backslash \text { City Departments and } \\
\text { Employees }\end{array}$ & Legal & 0.81 & 59 \\
\hline $\begin{array}{l}\text { Human Capital\Town\City Departments and } \\
\text { Employees }\end{array}$ & Contracts and Agreements & 0.82 & 54 \\
\hline $\begin{array}{l}\text { Human Capital\Town } \backslash \text { City Departments and } \\
\text { Employees }\end{array}$ & Sanitation Department & 0.82 & 51 \\
\hline $\begin{array}{l}\text { Human Capital } \backslash \text { Town } \backslash \text { City Departments and } \\
\text { Employees }\end{array}$ & Communication & 0.82 & 61 \\
\hline $\begin{array}{l}\text { Human Capital\Town } \backslash \text { City Departments and } \\
\text { Employees }\end{array}$ & Traffic Committee & 0.97 & 74 \\
\hline $\begin{array}{l}\text { Human Capital\Town } \backslash \text { City Departments and } \\
\text { Employees }\end{array}$ & City Employee Benefits & 1.15 & 69 \\
\hline $\begin{array}{l}\text { Human Capital\Town } \backslash \text { City Departments and } \\
\text { Employees }\end{array}$ & Finance Committee & 1.21 & 84 \\
\hline $\begin{array}{l}\text { Human Capital\Town } \backslash \text { City Departments and } \\
\text { Employees }\end{array}$ & Street Department & 1.21 & 74 \\
\hline $\begin{array}{l}\text { Human Capital\Town\City Departments and } \\
\text { Employees\Building Commission }\end{array}$ & Building Inspectors & 0.35 & 26 \\
\hline Human Capital\Town\Crime and Death & Drugs and Alcohol & 0.24 & 24 \\
\hline Human Capital\Town\Crime and Death & Vandalism & 0.25 & 24 \\
\hline Human Capital\Town\Culture & Museum & 0.10 & 10 \\
\hline Human Capital\Town\Culture & Festival & 0.12 & 10 \\
\hline Human Capital\Town\Economic Development & Corporations & 0.34 & 28 \\
\hline Human Capital\Town\Economic Development & Jobs & 0.34 & 29 \\
\hline Human Capital $\backslash$ Town $\backslash$ Economic Development & Small Business & 2.09 & 100 \\
\hline
\end{tabular}




\begin{tabular}{|c|c|c|c|}
\hline $\begin{array}{l}\text { Human Capital\Town } \backslash \text { Economic } \\
\text { Development } \mid C o r p o r a t i o n s\end{array}$ & Natural Gas Company & 0.35 & 21 \\
\hline $\begin{array}{l}\text { Human Capital\Town } \backslash \text { Economic } \\
\text { Development } \backslash \text { Corporations } \backslash \text { Natural Gas } \\
\text { Company }\end{array}$ & Transient Workers & 0.20 & 13 \\
\hline Human Capital\Town\Finances & Revenues & 0.46 & 27 \\
\hline Human Capital\Town\Finances & Donation & 0.60 & 43 \\
\hline Human Capital\Town\Finances & Grants & 1.31 & 73 \\
\hline $\begin{array}{l}\text { Human Capital } \backslash \text { Town } \backslash \text { Human Health and } \\
\text { Environment }\end{array}$ & Personal Health & 0.13 & 13 \\
\hline $\begin{array}{l}\text { Human Capital } \backslash \text { Town } \backslash \text { Human Health and } \\
\text { Environment }\end{array}$ & Conservation and Energy Efficiency & 0.15 & 13 \\
\hline $\begin{array}{l}\text { Human Capital\Town } \backslash \text { Human Health and } \\
\text { Environment }\end{array}$ & Health Care & 0.21 & 19 \\
\hline $\begin{array}{l}\text { Human Capital\Town } \backslash \text { Non Profits and } \\
\text { Organizations }\end{array}$ & Family Resource Network & 0.12 & 9 \\
\hline Human Capital\Town\Population & Citizen & 2.23 & 99 \\
\hline Human Capital\Town\Population\Citizen & family & 0.12 & 11 \\
\hline Human Capital\Town\Population\Citizen & Neighbor Disputes & 0.18 & 18 \\
\hline Human Capital\Town\Population\Citizen & Youth & 1.38 & 89 \\
\hline Human Capital|Town\Population\Citizen & Concerned Citizen & 3.07 & 116 \\
\hline Human Capital\Town $\backslash$ Public Safety & Medical Service & 0.20 & 18 \\
\hline Human Capital\Town $\backslash$ Public Safety & Fire Department & 1.64 & 98 \\
\hline Human Capital\Town\Public Safety & Police & 3.30 & 115 \\
\hline Human Capital|Town\University & Community Design Team & 0.06 & 6 \\
\hline Natural Capital & Soil and or Land & 0.10 & 10 \\
\hline Natural Capital & & 0.20 & 16 \\
\hline Natural Capital & Coal & 0.28 & 23 \\
\hline Natural Capital & Animals & 0.35 & 26 \\
\hline Natural Capital & natural gas & 0.35 & 29 \\
\hline Natural Capital & Water & 0.38 & 31 \\
\hline Natural Capital & Weather Related & 0.66 & 42 \\
\hline Natural Capital & Trees & 0.74 & 55 \\
\hline Physical Capital & Decorations & 0.04 & 6 \\
\hline Physical Capital & Trails & 0.16 & 17 \\
\hline Physical Capital & Property & 0.23 & 18 \\
\hline Physical Capital & Infrastructure & 0.37 & 30 \\
\hline Physical Capital & Debris & 0.51 & 35 \\
\hline Physical Capital & Technology & 0.56 & 43 \\
\hline Physical Capital & Parks & 1.42 & 82 \\
\hline Physical Capital & & 1.68 & 88 \\
\hline Physical Capital & Vehicles and Equipment & 2.10 & 92 \\
\hline Physical CapitalIInfrastructure & Electric Lines & 0.16 & 17 \\
\hline Physical CapitalIInfrastructure & Sidewalks & 0.90 & 77 \\
\hline Physical CapitalIInfrastructure & Water and Sewer & 0.90 & 64 \\
\hline Physical Capital/Infrastructure & Street Lights and Signals & 0.94 & 71 \\
\hline Physical Capital/Infrastructure & Parking & 1.14 & 82 \\
\hline Physical CapitalIInfrastructure & Roads, bridges, and alleys & 5.29 & 130 \\
\hline Physical Capital/Property & Annexation & 0.10 & 10 \\
\hline
\end{tabular}




\begin{tabular}{|c|c|c|c|}
\hline Physical Capital\Property & Zoning & 1.71 & 81 \\
\hline Physical Capital\Property & Buildings & 2.23 & 104 \\
\hline Physical Capital\Property\Buildings & Moundsville Prison & 0.06 & 8 \\
\hline Physical Capital\Property\Buildings & Strand Theater & 0.07 & 9 \\
\hline Physical Capital\Property\Buildings & Sanford Center & 0.24 & 24 \\
\hline Physical Capital\Property\Buildings & School Building & 0.51 & 37 \\
\hline Physical Capital\Property\Buildings & Fostoria & 1.17 & 82 \\
\hline Physical Capital\Property\Buildings & Housing & 1.30 & 77 \\
\hline Physical Capital\Property\Buildings & Property Nuisance & 2.36 & 97 \\
\hline Physical Capital\Property \Buildings $\backslash$ Housing & Trailers, Campers, RVs & 0.63 & 46 \\
\hline Physical Capital\Property\Buildings\Housing & $\begin{array}{l}\text { Dilapidated Aging or Vacant } \\
\text { Structures }\end{array}$ & 1.71 & 87 \\
\hline
\end{tabular}


Appendix C: Participant Observation Photos of Moundsville, West Virginia.

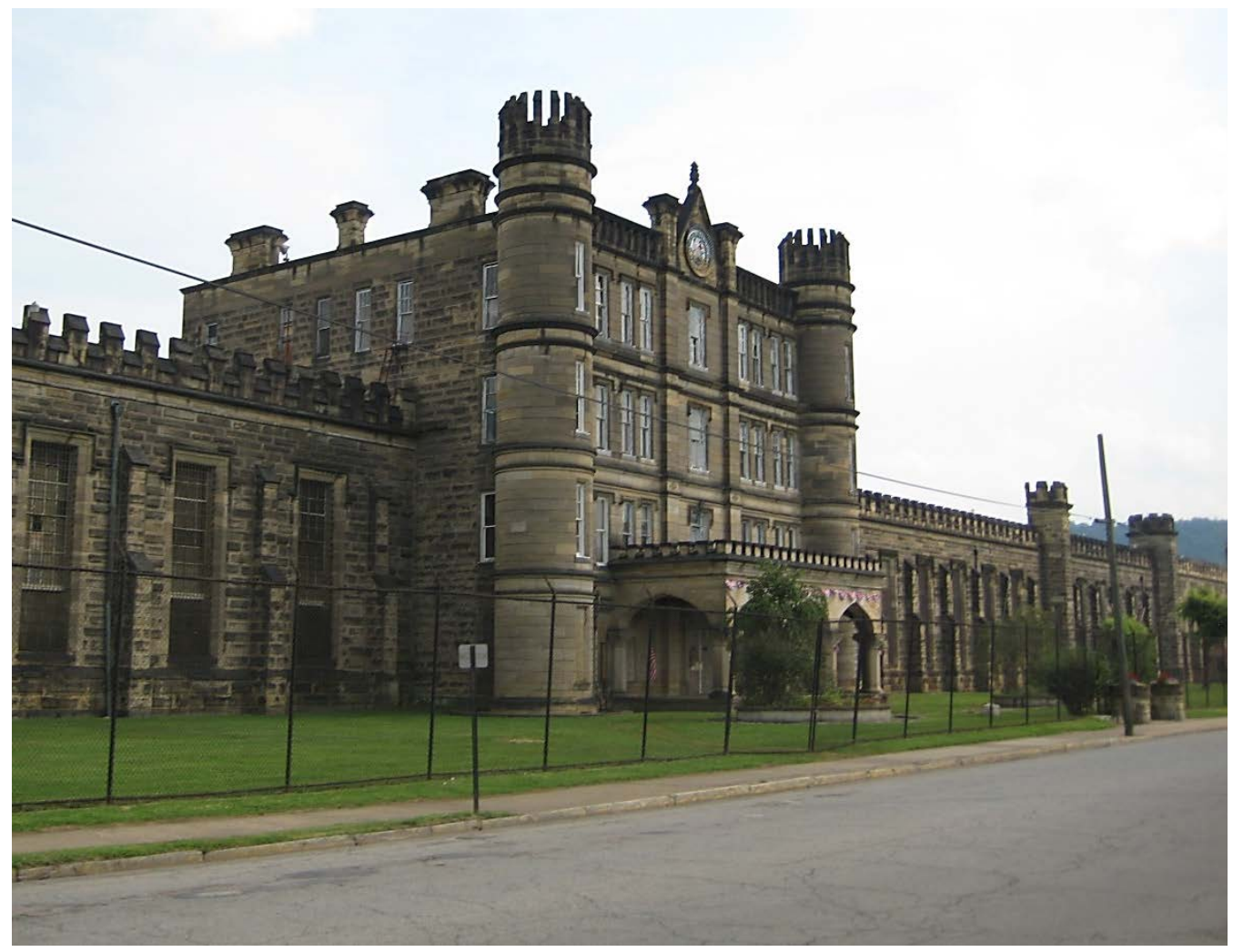

Figure 40. Moundsville Penitentiary, Moundsville. Kiger, B. (Photographer), 2012.

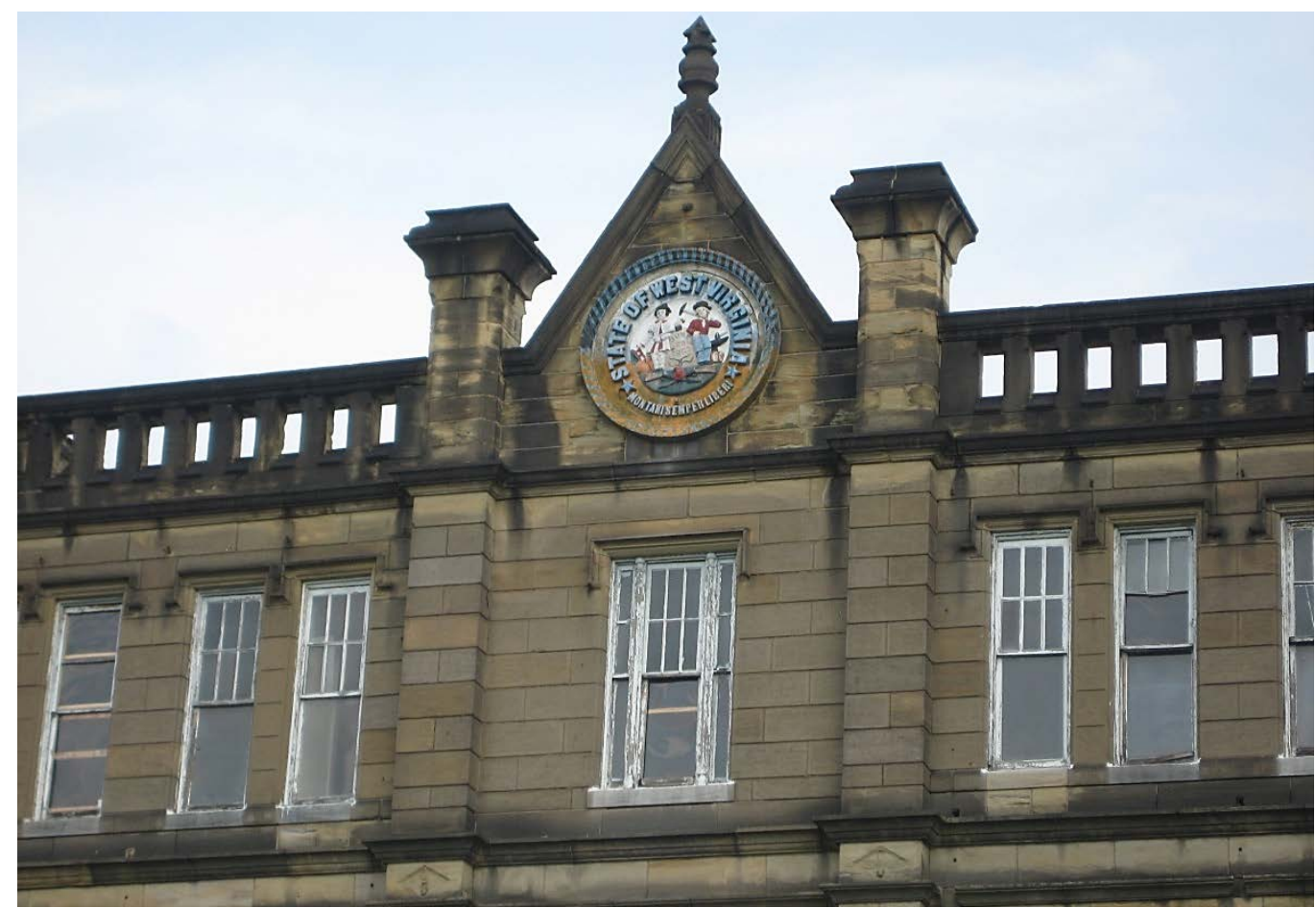

Figure 41. Moundsville Penitentiary, Moundsville. Kiger, B. (Photographer), 2012. 


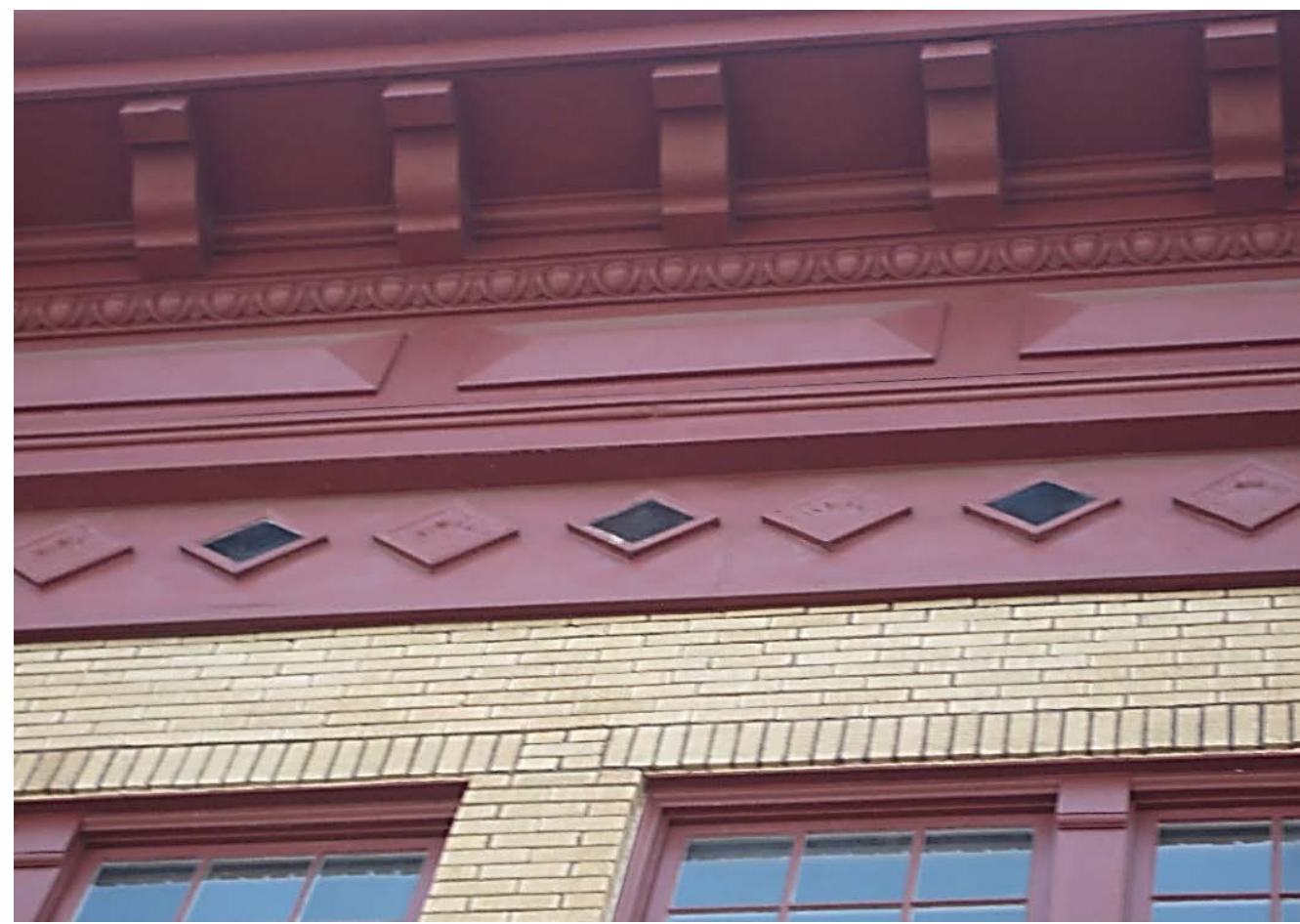

Figure 42. Exterior Strand Theater, Moundsville. Kiger, B. (Photographer), 2012.

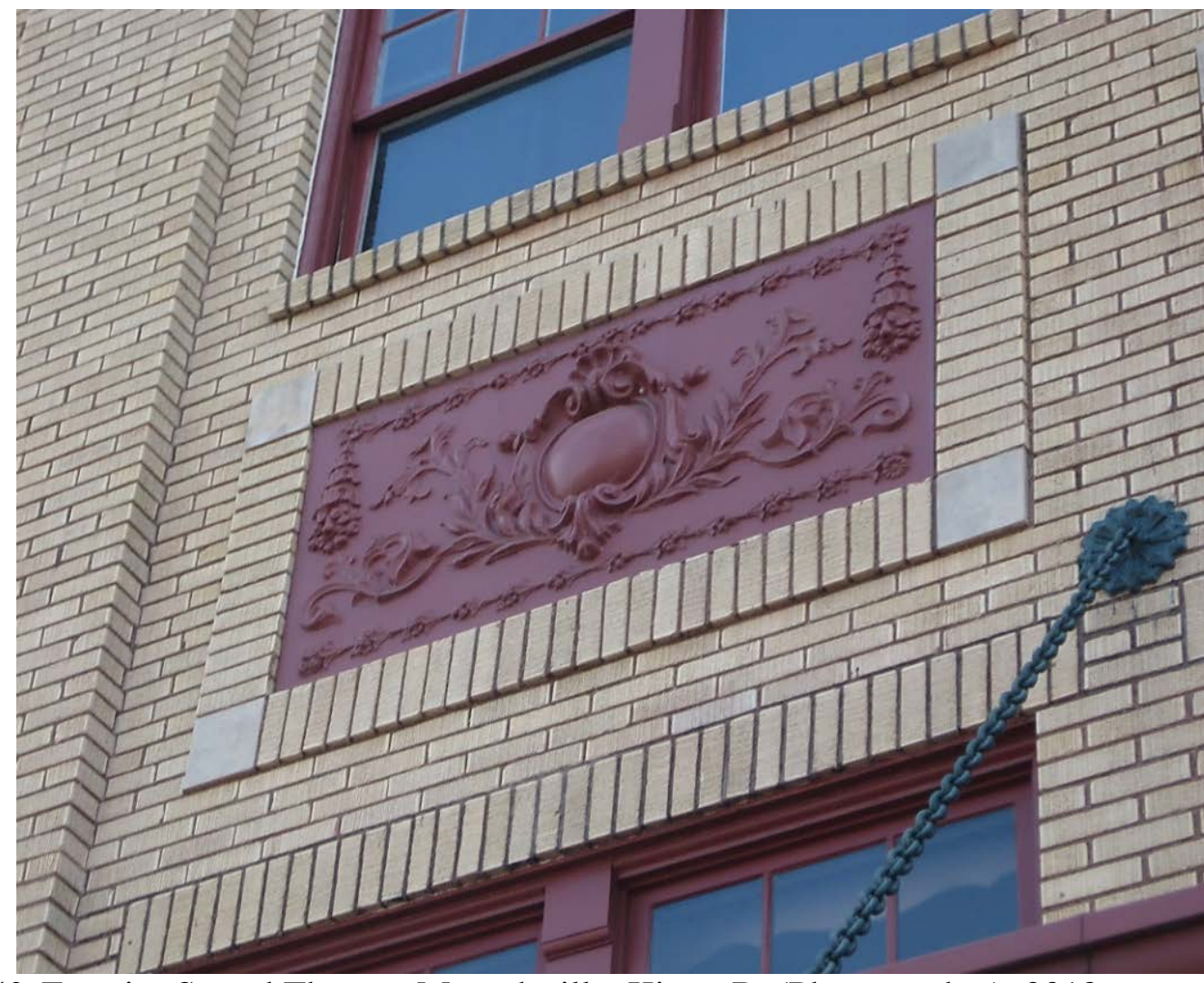

Figure 43. Exterior Strand Theater, Moundsville. Kiger, B. (Photographer), 2012. 